\title{
Pharmacological interventions for drug-using offenders (Review)
}

Perry AE, Neilson M, Martyn-St James M, Glanville JM, Woodhouse R, Godfrey C, Hewitt C
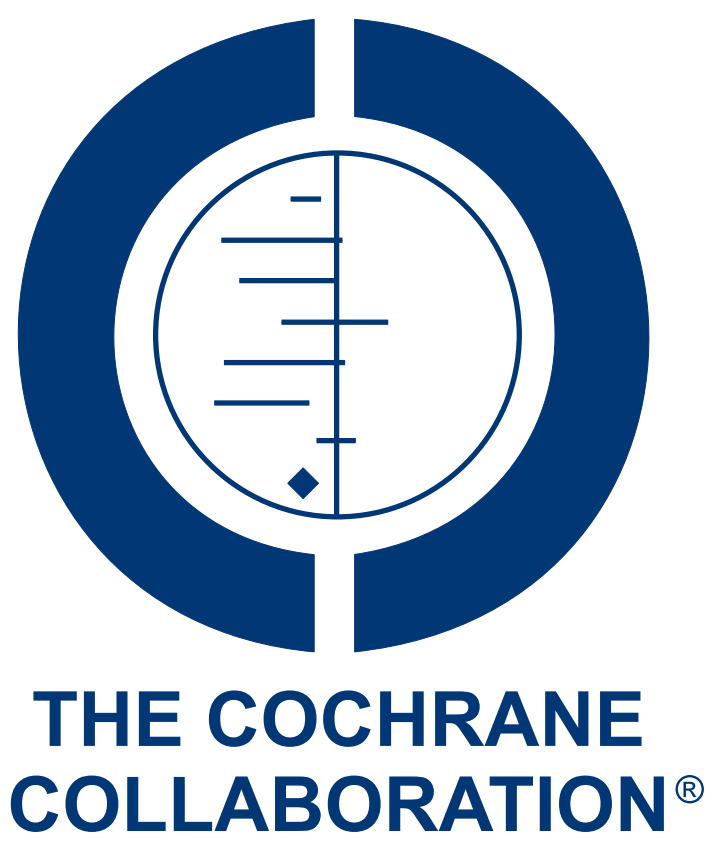

This is a reprint of a Cochrane review, prepared and maintained by The Cochrane Collaboration and published in The Cochrane Library 2015, Issue 6

http://www.thecochranelibrary.com

\section{WILEY}

Pharmacological interventions for drug-using offenders (Review)

Copyright $\odot 2015$ The Cochrane Collaboration. Published by John Wiley \& Sons, Ltd. 
TABLE OF CONTENTS

HEADER . . . . . . . . . . . . . . . . . . . . . . . . . . . . . . . . . . . . . . . . 1

ABSTRACT . . . . . . . . . . . . . . . . . . . . . . . . . . . . . . . . . . . . . . . . . . . . . . . . . .

PLAIN LANGUAGE SUMMARY . . . . . . . . . . . . . . . . . . . . . . . . . . . . . . . . . . . .

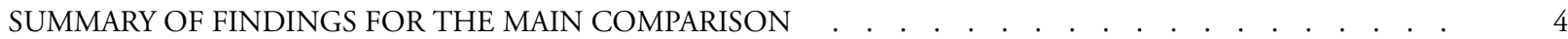

BACKGROUND . . . . . . . . . . . . . . . . . . . . . . . . . . . . . . . . . . . . . . . 7

OBJECTIVES . . . . . . . . . . . . . . . . . . . . . . . . . . . . . . . . . . . . . . . . . . . . . . . . . .

METHODS . . . . . . . . . . . . . . . . . . . . . . . . . . . . . . . . . . . . . . .

RESULTS . . . . . . . . . . . . . . . . . . . . . . . . . . . . . . . . . . . . . . . 11

Figure 1. . . . . . . . . . . . . . . . . . . . . . . . . . . . . . . . . . . . . 12

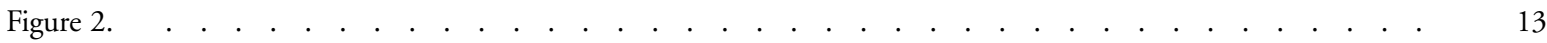

Figure 3. . . . . . . . . . . . . . . . . . . . . . . . . . . . . . . . . . . . . . 15

Figure $4 . \quad$. . . . . . . . . . . . . . . . . . . . . . . . . . . . . . . . . . . . . 17

Figure $5 . \quad$. . . . . . . . . . . . . . . . . . . . . . . . . . . . . . . . . . . . . 18

ADDITIONAL SUMMARY OF FINDINGS . . . . . . . . . . . . . . . . . . . . . . . . . . . . . . .

DISCUSSION . . . . . . . . . . . . . . . . . . . . . . . . . . . . . . . . . . . . . . 23

AUTHORS' CONCLUSIONS . . . . . . . . . . . . . . . . . . . . . . . . . . . . . . . . . 25

ACKNOWLEDGEMENTS . . . . . . . . . . . . . . . . . . . . . . . . . . . . . . . . . . . . . . . . . .

REFERENCES . . . . . . . . . . . . . . . . . . . . . . . . . . . . . . . . . . . . . . . . 26

CHARACTERISTICS OF STUDIES . . . . . . . . . . . . . . . . . . . . . . . . . . . . . . . . . . . . . . .

DATA AND ANALYSES . . . . . . . . . . . . . . . . . . . . . . . . . . . . . . . . . . . . . . . . . . . . . . . . .

Analysis 1.1. Comparison 1 Agonist pharmacological vs no intervention, Outcome 1 Drug use (objective). . . . . 71

Analysis 1.2. Comparison 1 Agonist pharmacological vs no intervention, Outcome 2 Drug use self reported dichotomous. 72

Analysis 1.3. Comparison 1 Agonist pharmacological vs no intervention, Outcome 3 Drug use self reported continuous. 73

Analysis 1.4. Comparison 1 Agonist pharmacological vs no intervention, Outcome 4 Criminal activity dichotomous. 74

Analysis 1.5. Comparison 1 Agonist pharmacological vs no intervention, Outcome 5 Criminal activity continuous. . 75

Analysis 2.1. Comparison 2 Antagonist (Naltrexone) vs no pharmacological, Outcome 1 Criminal activity dichotomous. 75

Analysis 2.2. Comparison 2 Antagonist (Naltrexone) vs no pharmacological, Outcome 2 drug use (objective). . . . 76

Analysis 3.1. Comparison 3 Methadone vs buprenorphine, Outcome 1 Self reported drug use dichotomous. $\quad$ . $\quad$. 77

Analysis 3.2. Comparison 3 Methadone vs buprenorphine, Outcome 2 Self reported drug use continuous. . . . . . 77

Analysis 3.3. Comparison 3 Methadone vs buprenorphine, Outcome 3 Criminal activity dichotomous. . . . . . 78

Analysis 4.1. Comparison 4 Methadone vs diamorphine, Outcome 1 criminal activity dichotomous. . . . . . . . . 78

Analysis 5.1. Comparison 5 Methadone vs naltrexone, Outcome 1 self reported drug use continuous. . . . . . . . 79

Analysis 5.2. Comparison 5 Methadone vs naltrexone, Outcome 2 criminal activity dichotomous. . . . . . . . . 79

Analysis 5.3. Comparison 5 Methadone vs naltrexone, Outcome 3 criminal activity continuous. . . . . . . . . 80

ADDITIONAL TABLES . . . . . . . . . . . . . . . . . . . . . . . . . . . . . . . . . . . 80

APPENDICES . . . . . . . . . . . . . . . . . . . . . . . . . . . . . . . . . . . . . . 83

WHAT'S NEW . . . . . . . . . . . . . . . . . . . . . . . . . . . . . . . . . . . . . 113

HISTORY . . . . . . . . . . . . . . . . . . . . . . . . . . . . . . . . . . . . . . . . 113

CONTRIBUTIONS OF AUTHORS . . . . . . . . . . . . . . . . . . . . . . . . . . . . . . . . . . . . . . . 114

DECLARATIONS OF INTEREST . . . . . . . . . . . . . . . . . . . . . . . . . . . . . . . . . . . . . . . . . 114

SOURCES OF SUPPORT . . . . . . . . . . . . . . . . . . . . . . . . . . . . . . . . . . . . . . . . . . . . . . . . .

DIFFERENCES BETWEEN PROTOCOL AND REVIEW . . . . . . . . . . . . . . . . . . . . . . . . . . . 115

INDEX TERMS . . . . . . . . . . . . . . . . . . . . . . . . . . . . . . . . . . . . . 115

Pharmacological interventions for drug-using offenders (Review)

Copyright $\odot 2015$ The Cochrane Collaboration. Published by John Wiley \& Sons, Ltd. 


\title{
[Intervention Review]
}

\section{Pharmacological interventions for drug-using offenders}

\author{
Amanda E Perry ${ }^{1}$, Matthew Neilson ${ }^{1}$, Marrissa Martyn-St James ${ }^{2}$, Julie M Glanville ${ }^{3}$, Rebecca Woodhouse ${ }^{1}$, Christine Godfrey ${ }^{1}$, \\ Catherine Hewitt ${ }^{1}$ \\ ${ }^{1}$ Department of Health Sciences, University of York, York, UK. ${ }^{2}$ School of Health and Related Research (ScHARR), University of \\ Sheffield, Sheffield, UK. ${ }^{3}$ York Health Economics Consortium, York, UK \\ Contact address: Amanda E Perry, Department of Health Sciences, University of York, Heslington, York, YO105DD, UK. \\ amanda.perry@york.ac.uk.
}

Editorial group: Cochrane Drugs and Alcohol Group.

Publication status and date: New search for studies and content updated (conclusions changed), published in Issue 6, 2015.

Review content assessed as up-to-date: 31 May 2014.

Citation: Perry AE, Neilson M, Martyn-St James M, Glanville JM, Woodhouse R, Godfrey C, Hewitt C. Pharmacological interventions for drug-using offenders. Cochrane Database of Systematic Reviews 2015, Issue 6. Art. No.: CD010862. DOI: 10.1002/14651858.CD010862.pub2.

Copyright (C) 2015 The Cochrane Collaboration. Published by John Wiley \& Sons, Ltd.

\begin{abstract}
A B S T R A C T
Background

The review represents one in a family of four reviews focusing on a range of different interventions for drug-using offenders. This specific review considers pharmacological interventions aimed at reducing drug use or criminal activity, or both, for illicit drug-using offenders.
\end{abstract}

\section{Objectives}

To assess the effectiveness of pharmacological interventions for drug-using offenders in reducing criminal activity or drug use, or both.

\section{Search methods}

We searched Fourteen electronic bibliographic databases up to May 2014 and five additional Web resources (between 2004 and November 2011). We contacted experts in the field for further information.

\section{Selection criteria}

We included randomised controlled trials assessing the efficacy of any pharmacological intervention a component of which is designed to reduce, eliminate or prevent relapse of drug use or criminal activity, or both, in drug-using offenders. We also report data on the cost and cost-effectiveness of interventions.

\section{Data collection and analysis}

We used standard methodological procedures as expected by Cochrane.

\section{Main results}

Fourteen trials with 2647 participants met the inclusion criteria. The interventions included in this review report on agonistic pharmacological interventions (buprenorphine, methadone and naltrexone) compared to no intervention, other non-pharmacological treatments (e.g. counselling) and other pharmacological drugs. The methodological trial quality was poorly described, and most studies were rated as 'unclear' by the reviewers. The biggest threats to risk of bias were generated through blinding (performance and detection bias) and incomplete outcome data (attrition bias). Studies could not be combined all together because the comparisons were too different. Only subgroup analysis for type of pharmacological treatment were done. When compared to non-pharmacological, we found low

Pharmacological interventions for drug-using offenders (Review)

Copyright $\odot 2015$ The Cochrane Collaboration. Published by John Wiley \& Sons, Ltd. 
quality evidence that agonist treatments are not effective in reducing drug use or criminal activity, objective results (biological) (two studies, 237 participants (RR 0.72 (95\% CI 0.51 to 1.00); subjective (self-report), (three studies, 317 participants (RR $0.6195 \%$ CI 0.31 to 1.18 ); self-report drug use (three studies, 510 participants (SMD: -0.62 (95\% CI -0.85 to -0.39 ). We found low quality of evidence that antagonist treatment was not effective in reducing drug use (one study, 63 participants (RR 0.69, 95\% CI 0.28 to 1.70) but we found moderate quality of evidence that they significantly reduced criminal activity (two studies, 114 participants, (RR 0.40 , $95 \%$ CI 0.21 to 0.74 ).

Findings on the effects of individual pharmacological interventions on drug use and criminal activity showed mixed results. In the comparison of methadone to buprenorphine, diamorphine and naltrexone, no significant differences were displayed for either treatment for self report dichotomous drug use (two studies, 370 participants (RR 1.04, 95\% CI 0.69 to 1.55), continuous measures of drug use (one study, 81 participants, (mean difference (MD) 0.70, 95\% CI -5.33 to 6.73); or criminal activity (one study, 116 participants, (RR $1.25,95 \%$ CI 0.83 to 1.88 ) between methadone and buprenorphine. Similar results were found for comparisons with diamorphine with no significant differences between the drugs for self report dichotomous drug use for arrest (one study, 825 participants, (RR 1.25, 95\% CI 1.03 to 1.51) or naltrexone for dichotomous measures of reincarceration (one study, 44 participants, (RR 1.10, $95 \%$ CI 0.37 to 3.26), and continuous outcome measure of crime, (MD - $0.50,95 \%$ CI -8.04 to 7.04 ) or self report drug use (MD $4.60,95 \%$ CI 3.54 to 12.74$)$.

\section{Authors' conclusions}

When compared to non-pharmacological treatment, agonist treatments did not seem effective in reducing drug use or criminal activity. Antagonist treatments were not effective in reducing drug use but significantly reduced criminal activity. When comparing the drugs to one another we found no significant differences between the drug comparisons (methadone versus buprenorphine, diamorphine and naltrexone) on any of the outcome measures. Caution should be taken when interpreting these findings, as the conclusions are based on a small number of trials, and generalisation of these study findings should be limited mainly to male adult offenders. Additionally, many studies were rated at high risk of bias.

\section{PLAIN LANGUAGE SUMMARY}

\section{Pharmacological interventions for drug-using offenders \\ Background}

Drug-using offenders by their nature represent a socially excluded group in which drug use is more prevalent than in the rest of the population. Pharmacological interventions play an important role in the rehabilitation of drug-using offenders. For this reason, it is important to investigate what we know works when pharmacological interventions are provided for offenders.

\section{Study characteristics}

The review authors searched scientific databases and Internet resources to identify randomised controlled trials (where participants are allocated at random to one of two or more treatment groups) of interventions to reduce, eliminate, or prevent relapse of drug use or criminal activity of drug-using offenders. We included males and female of any age or ethnicity.

\section{Key results}

We identified 14 trials of pharmacological interventions for drug-using offenders. The interventions included: (1) naltrexone in comparison with routine parole, social psychological treatment or both; (2) methadone maintenance in comparison with different counselling options; and (3) naltrexone, diamorphine and buprenorphine in comparison with a non-pharmacological alternative and in combination with another pharmacological treatment. Studies could not be combined all together because the comparisons were too different. When compared to non-pharmacological, we found low quality evidence that agonist treatments are not effective in reducing drug use or criminal activity. We found low quality of evidence that antagonist treatment was not effective in reducing drug use but we found moderate quality of evidence that they significantly reduced criminal activity. When comparing the drugs to one another we found no significant differences between the drug comparisons (methadone versus buprenorphine, diamorphine and naltrexone) on any of the outcome measures suggesting that one pharmacological drug does not preside over another. One study provided some cost comparisons between buprenorphine and methadone, but data were not sufficient to generate a cost-effectiveness analysis. In conclusion, we found that pharmacological interventions do reduce subsequent drug use and criminal activity (to a lesser extent). Additionally, we found individual differences and variation between the degree to which successful interventions were implemented and were able to sustain reduction of drug use and criminal activity.

Pharmacological interventions for drug-using offenders (Review) 


\section{Quality of evidence}

This review was limited by the lack of information reported in this group of trials and the quality of the evidence was low. The evidence is current to May 2014. 


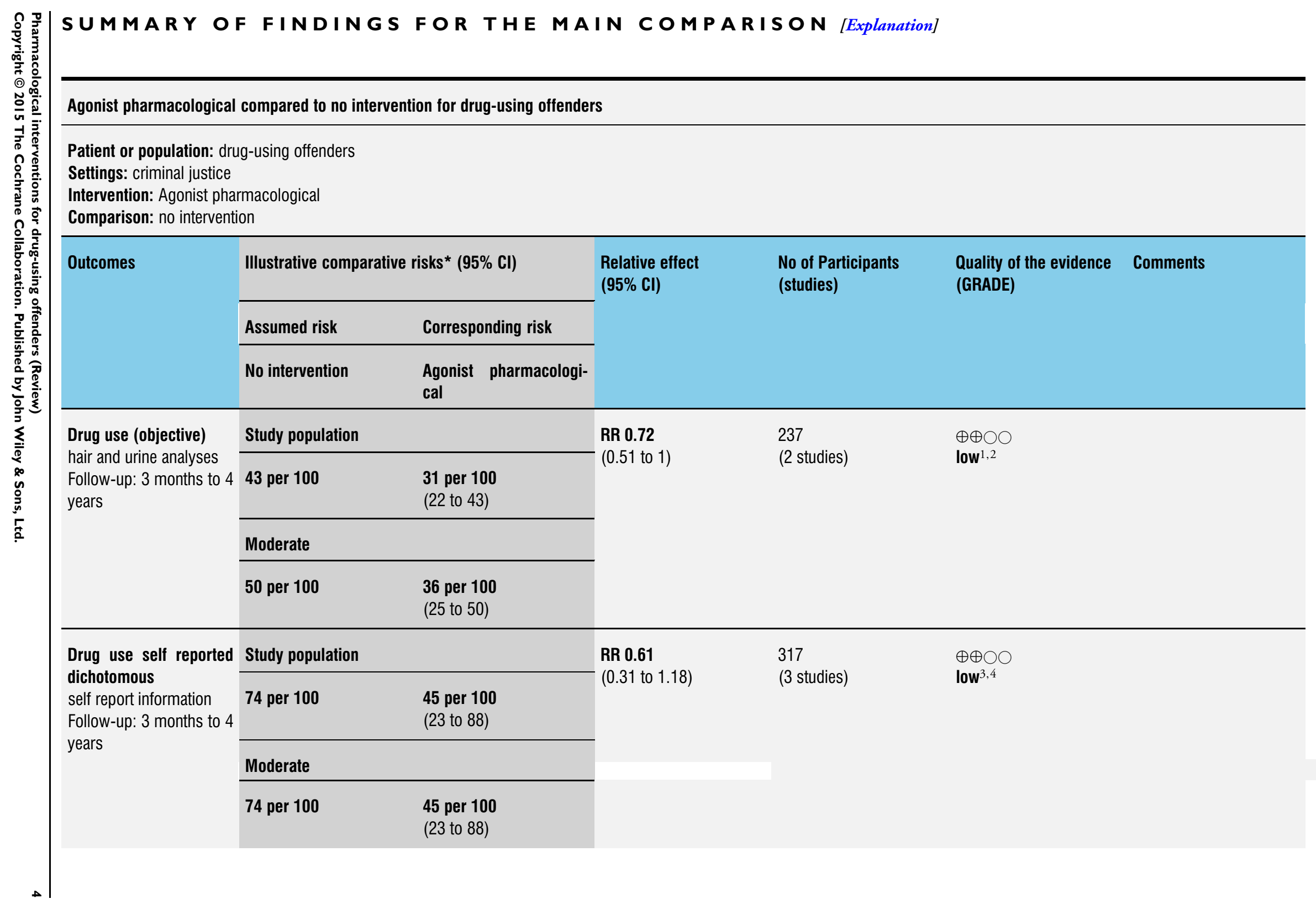




\begin{tabular}{|c|c|c|c|c|c|c|}
\hline $\begin{array}{l}\text { Drug use self reported } \\
\text { continuous } \\
\text { self report information } \\
\text { Follow-up: } 9 \text { months to } 4 \\
\text { years }\end{array}$ & & $\begin{array}{l}\text { The mean drug use self } \\
\text { reported continuous in the } \\
\text { intervention groups was } \\
\mathbf{0 . 6 2} \text { standard deviations } \\
\text { lower } \\
\text { ( } 0.85 \text { to } 0.39 \text { lower) }\end{array}$ & & $\begin{array}{l}510 \\
\text { (3 studies) }\end{array}$ & $\begin{array}{l}\oplus \oplus \bigcirc \bigcirc \\
\text { low }^{5,6}\end{array}$ & $\begin{array}{l}\text { SMD }-0.62(-0.85 \text { to }-0 . \\
39)\end{array}$ \\
\hline \multirow{4}{*}{$\begin{array}{l}\text { Criminal activity di- } \\
\text { chotomous - Arrests } \\
\text { official records } \\
\text { Follow-up: median } 9 \\
\text { months }\end{array}$} & Study popul & & \multirow{4}{*}{$\begin{array}{l}\text { RR } \mathbf{0 . 6} \\
(0.32 \text { to } 1.14)\end{array}$} & \multirow{4}{*}{$\begin{array}{l}62 \\
\text { (1 study) }\end{array}$} & \multirow{4}{*}{$\begin{array}{l}\oplus \oplus \bigcirc \bigcirc \\
\text { low }^{7,10}\end{array}$} & \\
\hline & 55 per 100 & $\begin{array}{l}33 \text { per } 100 \\
\text { (18 to } 63)\end{array}$ & & & & \\
\hline & \multicolumn{2}{|l|}{ Moderate } & & & & \\
\hline & 55 per 100 & $\begin{array}{l}33 \text { per } 100 \\
\text { (18 to } 63)\end{array}$ & & & & \\
\hline \multirow{4}{*}{$\begin{array}{l}\text { Criminal activity di- } \\
\text { chotomous - Re-incar- } \\
\text { ceration } \\
\text { official records } \\
\text { Follow-up: } 7 \text { months to } 4 \\
\text { years }\end{array}$} & Study popul & & \multirow{4}{*}{$\begin{array}{l}\text { RR } \mathbf{0 . 7 7} \\
-(0.36 \text { to } 1.64)\end{array}$} & \multirow{4}{*}{$\begin{array}{l}472 \\
\text { (3 studies) }\end{array}$} & \multirow{4}{*}{$\begin{array}{l}\oplus \oplus \bigcirc \bigcirc \\
\text { low }^{8,9}\end{array}$} & \\
\hline & 66 per 100 & $\begin{array}{l}\mathbf{5 1} \text { per } \mathbf{1 0 0} \\
(24 \text { to } 100)\end{array}$ & & & & \\
\hline & \multicolumn{2}{|l|}{ Moderate } & & & & \\
\hline & 83 per 100 & $\begin{array}{l}64 \text { per } 100 \\
(30 \text { to } 100)\end{array}$ & & & & \\
\hline $\begin{array}{l}\text { Criminal activity contin- } \\
\text { uous } \\
\text { mean number of crime } \\
\text { dayes } \\
\text { Follow-up: median } 9 \\
\text { months }\end{array}$ & & $\begin{array}{l}\text { The mean criminal activ- } \\
\text { ity continuous in the in- } \\
\text { tervention groups was } \\
\mathbf{7 4 . 2 1} \text { lower } \\
\text { (133.53 to } 14.89 \text { lower) }\end{array}$ & & $\begin{array}{l}51 \\
\text { (1 study) }\end{array}$ & $\begin{array}{l}\oplus \oplus \bigcirc \bigcirc \\
\text { low } 7,11\end{array}$ & \\
\hline
\end{tabular}

*The basis for the assumed risk (e.g. the median control group risk across studies) is provided in footnotes. The corresponding risk (and its $95 \%$ confidence interval) is based on the assumed risk in the comparison group and the relative effect of the intervention (and its $95 \% \mathrm{Cl}$ ).

CI: Confidence interval; RR: Risk ratio; 
GRADE Working Group grades of evidence

High quality: Further research is very unlikely to change our confidence in the estimate of effect.

Moderate quality: Further research is likely to have an important impact on our confidence in the estimate of effect and may change the estimate.

Low quality: Further research is very likely to have an important impact on our confidence in the estimate of effect and is likely to change the estimate.

Very low quality: We are very uncertain about the estimate.

${ }^{1}$ Across the two studies 10 of the 18 risk of bias items in total were rated as unclear.

${ }^{2}$ The total number of events across the two studies is less than 300. This is a threshold rule of thumb based on Muller et al Ann Intern

Med. 2007; 146: 878-881.

${ }^{3}$ Across the three studies 17 items were rated as unclear out of a total of 27 items.

${ }^{4}$ The $\mathrm{P}$ value for heterogenity is less than 0.05 and the $\mathrm{I}^{2}$ is $89 \%$ suggesting significant inconsistency between the studies.

${ }^{5}$ Across the three studies 16 of the 27 items on risk of bias were rated as unclear

${ }^{6}$ The $\mathrm{P}$ value for heterogenity is less than 0.05 and the $\mathrm{P}^{2}$ is $99 \%$ suggesting significant inconsistency across the studies.

${ }^{7} 6$ of the 9 risk of bias items were rated as unclear

${ }^{8}$ Across the three studies 17 of the 27 risk of bias items in total were rated as unclear

${ }^{9}$ The $\mathrm{P}$ value for heterogenity is less than 0.05 and the $\mathrm{I}^{2}$ is $74 \%$ suggesting significant heterogenity.

${ }^{10}$ only 1 study with 62 participants

${ }^{11}$ only 1 study with 51 participants 


\section{B A C K G R O U N D}

This review represents part of a family of four reviews undertaken to closely examine what works in reducing drug use and criminal activity among drug-using offenders. Overall, the four reviews contain over 100 trials, generating a number of publications and numerous comparisons (Perry 2013a; Perry 2013b; Perry 2013c). The four reviews represent specific interests in pharmacological interventions, non-pharmacological interventions, female offenders and offenders with co-occurring mental illness. All four reviews stem from an updated previous Cochrane systematic review (Perry 2006). In this set of four reviews, we consider the effectiveness of interventions based on two key outcomes and analyse the impact of setting and intervention type. Presented here is the revised methodology for this individual review, focusing on the impact of pharmacological interventions provided for drug-using offenders.

\section{Description of the condition}

Offenders as a socially excluded group of people demonstrate significant drug use and subsequent health problems. Studies investigating the prevalence of drug dependence in UK prisons report variable results of 10\% (Gunn 1991), 39\% (Brooke 1996), and $33 \%$ (Mason 1997). Similar trends have been reported elsewhere. In France, 30\% of prison inmates are heroin addicted, and in Australia, 59\% of prison inmates report injecting (primarily heroin) drug use histories. In the US, it is recognised that many offenders are in need of treatment to tackle their drug use (Lo 2000). The link between drug use, subsequent health and social and criminological consequences is well documented in the literature (e.g. Michel 2005), and offenders have a high risk of death from opioid overdose within two weeks of release from incarceration (Bird 2003; Binswanger 2007). Substance use disorders are linked to criminal behaviour and are a significant burden on the criminal justice system. Approximately $30 \%$ of acquisitive crime is committed by individuals supporting drug use with the use of criminal acts (Magura 1995).

\section{Description of the intervention}

Internationally, methadone maintenance has been the primary choice for chronic opioid dependence in prisons and jails, including those in the Netherlands, Australia, Spain and Canada, and it is being increasingly implemented in the criminal justice setting (Moller 2007; Stallwitz 2007). The US has not generally endorsed the use of methadone treatment, and only $12 \%$ of correctional settings offer this option for incarcerated inmates (Fiscella 2004). Reasons for this lack of expansion suggest that public opinion and that of criminal justice system providers consider methadone treatment as substituting one addiction for another. In contrast, buprenorphine appears not to carry the same social stigma associated with methadone treatment and has been used in France,
Austria and Puerto Rico (Catania 2003; Reynaud-Maurupt 2005; Garcia 2007). Naltrexone treatment has shown some promising findings, but associated problems surrounding high attrition and low medication compliance in the community and high mortality rates (e.g. Gibson 2007; Minozzi 2011) pose concerns. Trials conducted in the criminal justice setting are still lacking, and continuity of care is considered crucial in the treatment of drug-involved offenders who transition between prison and the community.

\section{How the intervention might work}

A growing body of evidence shows the effects of pharmacological interventions for drug use among the general population. Existing reviews have focused on naltrexone maintenance treatment for opioid dependence (Amato 2005; Lobmaier 2008; Minozzi 2011); and the efficacy of methadone (Marsch 1998; Faggiano 2003; Mattick 2009); and buprenorphine maintenance (Mattick 2009). Recent guidance has been provided from the National Institute for Health and Clinical Excellence on evidence-based use of naltrexone, methadone and buprenorphine for the management of opioid dependence (NICE 2007a; NICE 2007b). Five Cochrane reviews (including 52 studies) reported on the effectiveness of opiate methadone therapies (Amato 2005). Findings showed that methadone maintenance therapies at appropriate doses were most effective in retaining participants in treatment and in suppressing heroin use, but evidence of effectiveness for other relevant outcome measures such as criminal activity was weak and was not systematically evaluated.

Systematic reviews evaluating treatment programs more generally for offender populations have focused on evaluating treatment in one setting such as community-based programmes, (e.g. Mitchell, 2012a; Mitchell, 2012b); or have based their evidence on literature from one country (e.g. Germany or the US) (Chanhatasilpa 2000; Egg 2000); or a number of specific treatments (Mitchell 2006). Pharmacological systematic reviews of offender treatment appear to be sparse. We identified two previous reviews, one focusing on specific drug- and property-related criminal behaviours in methadone maintenance treatment (Marsch 1998); and an evaluation of the effectiveness of opioid maintenance treatment (OMT) in prison and post-release (Hedrich 2011). The later of these two reviews identified six experimental studies up until January 2011 (Hedrich 2011). The authors found that OMT in prison was significantly associated with reduced heroin use, injecting and syringe sharing. Use of pre-release OMT was also found to have important implications for associated treatment uptake after release, but the impact on criminal activity was equivocal.

\section{Why it is important to do this review}

The current review provides a systematic examination of trial evidence relating to the effectiveness of pharmacological interven- 
tions for drug-using offenders. We believe it is important to conduct this review because the evidence about pharmacological interventions for drug-using offenders has not been evaluated in this manner before. In order to address this broad topic a series of questions will consider the effectiveness of different interventions in relation to criminal activity, drug misuse treatment setting and type of treatment. The review will additionally report descriptively on the costs and cost effectiveness of such treatment programs.

\section{O B J E C T I VES}

To assess the effectiveness of pharmacological interventions for drug-using offenders in reducing criminal activity or drug misuse or both. The review addressed the following questions:

- Does any pharmacological treatment for drug-using offenders reduce drug use?

- Does any pharmacological treatment for drug-using offenders reduce criminal activity?

- Does the treatment setting (e.g. court, community, prison/ secure establishment) affect outcome(s) of pharmacological treatments?

- Does one type of pharmacological treatment perform better than one other?

Additionally, this review aimed to report on the cost and costeffectiveness of interventions.

\section{METHODS}

\section{Criteria for considering studies for this review}

\section{Types of studies}

Randomised controlled trials (RCTs)

\section{Types of participants}

We included illicit drug-misusing offenders in the review regardless of gender, age, ethnicity or psychiatric illness. Drug misuse includes individuals occasionally using drugs, or who are dependent on, or are known to abuse, drugs. Offenders are defined as individuals who were subject to the criminal justice system.

\section{Types of interventions}

Included interventions were designed, wholly or in part, to eliminate or prevent relapse to drug use or criminal activity, or both, among participants. We defined relapse as individuals who may have returned to an incarcerated setting, or had subsequently been arrested or had relapsed back into drug misuse, or both. We included a range of different types of interventions in the review.

Experimental interventions included in the review:

- Any pharmacological intervention (e.g. buprenorphine, methadone)

\author{
Control interventions included in the review. \\ - No treatment \\ - Minimal treatment \\ - Waiting list \\ - Treatment as usual \\ - Other treatment (e.g. pharmacological or psychosocial)
}

\section{Types of outcome measures}

\section{Primary outcomes}

For the purpose of our review we categorised our primary outcomes into those relating to dichotomous and continuous drug use or criminal activity, or both. Where papers reported a number of different follow-up periods, we report the longest time period, as we felt that such measures provide the most conservative estimate of effectiveness. For specific meta-analyses of sub-groupings, we reviewed all reported follow-up periods to select the most appropriate time period for combining comparable studies.

- Drug use measures were reported as:

- self-report drug use (unspecified drug, specific drug use not including alcohol/tobacco, Addiction Severity Index drug composite scores); and

- biological drug use (measured by drugs tested by urine or hair analysis).

- Criminal activity as measured by:

o self-report or official report of criminal activity (including arrest for any offence, drug offences, reincarceration, convictions, charges and recidivism).

\section{Secondary outcomes}

Our secondary outcome reported on costs or cost-effectiveness information. We used a descriptive narrative for these findings. We undertook a full critical appraisal based on the Drummond 1997 checklist for those studies presenting sufficient information. 


\section{Search methods for identification of studies}

\section{Electronic searches}

\section{Electronic searches}

The update searches identified records from 2004 to May 2014

- CENTRAL (Issue 5, 2014).

- MEDLINE (1966 to May 2014).

- EMBASE (1980 to May 2014).

- PsycINFO (1978 to April 2014).

- Pascal (1973 to November 2004) ${ }^{a}$.

- SciSearch (Science Citation Index) (1974 to April 2014).

- Social SciSearch (Social Science Citation Index) (1972 to April 2014).

- ASSIA (1987 to May 2014).

- Wilson Applied Science and Technology Abstracts (1983 to October 2004) ${ }^{a}$.

- Inside Conferences (1993 to November 2004) ${ }^{a}$.

- Dissertation Abstracts (1961 to October 2004) ${ }^{a}$.

- NTIS (1964 to April 2014).

- Sociological Abstracts (1963 to April 2014).

- HMIC (to April 2014).

- PAIS (1972 to April 2014).

- SIGLE (1980 to June 2004) ${ }^{b}$.

- Criminal Justice Abstracts (1968 to April 2014).

- LILACS (2004 to April 2014).

- National Research Register (March 2004) ${ }^{c}$.

- Current Controlled Trials (December 2009).

- Drugscope (February 2004)- unable to access.

- SPECTR (March 2004) .

${ }^{a}$ Unable to access further to 2004 search.

${ }^{b}$ Database not updated since original 2004 search.

${ }^{c}$ No longer exists.

${ }^{d}$ Now Campbell Collaboration searched on line.

To update the original review (Perry 2006), the search strategy was restricted to studies that were published or unpublished from 2004 onwards. A number of original databases were not searched for this update (indicated by the key at the end of the database list). Pascal, ASSIA, Wilson Applied Science and Technology Abstracts, Inside Conferences and Dissertation Abstracts were not searched. These databases are available only via the fee-charging DIALOG online host service: we did not have the resources to undertake these searches. The National Research Register no longer exists, and SIGLE has not been updated since 2005. Drugscope is available only to subscribing members. The original searches were undertaken by Drugscope staff.

Search strategies were developed for each database to exploit the search engine most effectively and to make use of any controlled vocabulary. Search strategies were designed to restrict the results to RCTs. No language restriction was placed on the search results. We included methodological search filters designed to identify tri- als. Whenever possible, filters retrieved from the InterTASC Information Specialists' Sub-Group (ISSG) Search Filter Resource site (http://www.york.ac.uk/inst/crd/intertasc/) were used. If filters were unavailable from this site, search terms based on existing filters were used instead.

In addition to the electronic databases, a range of relevant Internet sites (Home Office, National Institute of Drug Abuse (NIDA) and European Association of Libraries and Information Services on Alcohol and Other Drugs (ELISAD)) were searched. Directory web sites, including OMNI (http://www.omni.ac.uk), were searched up until November 2011. The review did not place any language restrictions on identification and inclusion of studies in the review.

Details of the update search strategies and results and of the Internet sites searched are listed in Appendix 1; Appendix 2; Appendix 3; Appendix 4; Appendix 5; Appendix 6; Appendix 7; Appendix 8; Appendix 9; Appendix 10; Appendix 11; Appendix 12; Appendix 13.

\section{Searching other resources}

Reference checking

We scrutinised the reference lists of all retrieved articles for further references, and also undertook searches of the catalogues of relevant organisations and research founders.

Personal communication

We contacted experts for their knowledge of other studies, published or unpublished, relevant to the review.

\section{Data collection and analysis}

\section{Selection of studies}

Two authors independently inspected the search hits by reading the titles and abstracts, and obtained each potentially relevant study located in the search as a full-text article to independently assess them for inclusion. In the case of discordance, a third independent author arbitrated. One author undertook translation of articles not written in the English language.

The screening process was divided into two key phases. Phase one used the initial seven key questions reported in the original new reference review. These were:

\section{Prescreening criteria: phase one}

- Is the document an empirical study? [If "no" exclude document.]

- Does the study evaluate an intervention, a component of which is designed to reduce, eliminate or prevent relapse among drug-using offenders?

- Are the participants referred by the criminal justice system at baseline?

- Does the study report pre-programme and post-programme measures of drug use? 
- Does the study report pre-programme and post-programme measures of criminal behaviour?

- Is the study a randomised controlled trial?

- Do the outcome measures refer to the same length of follow-up for two groups?

After relevant papers from phase one had been identified, phase two screening was performed to identify papers reporting on pharmacological interventions. Criteria included the following.

\section{Prescreening: phase two}

- Is the intervention a pharmacological intervention? [if "yes" include document]

Drug-using interventions were implied if the programme targeted reduced drug use in a group of individuals. Offenders were individuals either residing in special hospitals, prisons, the community (i.e. under the care of the probation service) or diverted from court or placed on arrest referral schemes for treatment. We included studies in the review where the sample were not entirely drug-using, but reported pre- and post-measures. The study setting could change throughout the process of the study, e.g. offenders could begin in prison but progress through a work-release project into a community setting. Finally, studies did not need to report both drug and criminal activity outcomes: if either of these was reported we included the study in the review.

\section{Data extraction and management}

We used data extraction forms to standardise the reporting of data from all studies obtained as potentially relevant. Two authors independently extracted data and subsequently checked them for agreement.

\section{Assessment of risk of bias in included studies}

Five independent review authors (AEP, JMG, MM-SJ, MN, RW) assessed risk of bias in all included studies using risk of bias assessment criteria recommended in the Cochrane Handbook for Systematic Reviews of Interventions (Higgins 2011).

The risk of bias assessment for RCTs in this review was performed using the criteria recommended by the Cochrane Handbook for Systematic Reviews of Interventions (Higgins 2011). The recommended approach for assessing risk of bias in studies included in a Cochrane Review involves the use of a two-part tool that addresses six specific domains, namely, sequence generation and allocation concealment (selection bias), blinding of participants and providers (performance bias), blinding of outcome assessor (detection bias), incomplete outcome data (attrition bias), selective outcome reporting (reporting bias), and other sources of bias. The first part of the tool involves describing what was reported to have happened in the study. The second part of the tool involves assigning a judgement related to the risk of bias for that entry in terms of low, high or unclear risk. To make these judgements, we used the criteria indicated by the Cochrane Handbook for Systematic Reviews of Interventions as adapted for the addiction field.

The domains of sequence generation and allocation concealment (avoidance of selection bias) were addressed in the tool by a single entry for each study.

Blinding of participants, personnel and outcome assessor (avoidance of performance bias and detection bias) was considered separately for objective outcomes (e.g. dropping out, using substance of abuse as measured by urinalysis, relapsing of participants at the end of follow-up, engaging of participants in further treatments) and subjective outcomes (e.g. duration and severity of signs and symptoms of withdrawal, participant self-reported use of substance, side effects, social functioning as integration at school or at work, family relationships).

Incomplete outcome data (avoidance of attrition bias) were considered for all outcomes except dropping out of treatment, which very often is the primary outcome measure in trials on addiction. See Appendix 14 for details.

For studies identified in the most recent search, the review authors attempted to contact study authors to establish whether a study protocol was available.

\section{Measures of treatment effect}

The mean differences (MD) were used for outcomes measured on the same scale and the standardised mean difference (SMD) for outcomes measured on different scales. Higher scores for continuous measures are representative of greater harm. We present dichotomous outcomes as risk ratios (RR), with $95 \%$ confidence intervals (CIs).

\section{Unit of analysis issues}

To avoid double counting of outcome measures (e.g. arrest and parole violation) and follow up time periods (e.g. 12, 18 months) all trials were checked to ensure that multiple studies reporting the same evaluation did not contribute towards multiple estimates of programme effectiveness. We followed Cochrane guidance and where appropriate we combined intervention and control groups to create a single pairwise comparison. Where this was not appropriate we selected one treatment arm and excluded the others.

\section{Dealing with missing data}

Where we found data was missing in the original publication, we attempted to contact the study authors via email to obtain the missing information.

\section{Assessment of heterogeneity}

Heterogenity was assessed using $\mathrm{I}^{2}$ and Q statistics (Higgins 2011). 


\section{Data synthesis}

The RevMan software package was used to perform a series of meta-analyses for continuous and dichotomous outcome measures (Review Manager 2014). A random-effects model was used to account for the fact that participants did not come from a single underlying population. A narrative review were performed to address each of the key questions outlined in the objectives. The narrative tables included a presentation of study details (e.g. author, year of publication, and country of study origin), study methods (e.g. random assignment), participants (e.g. number in sample, age, gender, ethnicity, age, mental health status), interventions (e.g. description, duration, intensity, setting), outcomes (e.g. description, follow-up period, reporting mechanism), resource and cost information and resource savings (e.g. number of staff, intervention delivery, estimated costs, estimated savings), and notes (e.g. methodological and quality assessment information). For outcomes of criminal activity, data were sufficient to allow the review authors to divide this activity into "re-arrest" and reincarceration categories.

\section{Subgroup analysis and investigation of heterogeneity}

A separate subgroup analysis of the studies was planned by different types of treatments and different settings.

\section{Sensitivity analysis}

When appropriate, sensitivity analyses were planned to assess the impact of studies with high risk of bias. Because of the overall high risk of bias of the included studies, this analysis was not conducted.

\section{RES U L T S}

\section{Description of studies}

\section{Results of the search}

\section{Original review}

The original searches spanned from database inception to October 2004. This identified a total of 8217 records after duplication. We acquired a total of 90 full text papers for assessment and excluded 66 papers, bringing 24 trials to the review (see Figure 1). 
Figure I. Study flow diagram of paper selection: Original Review

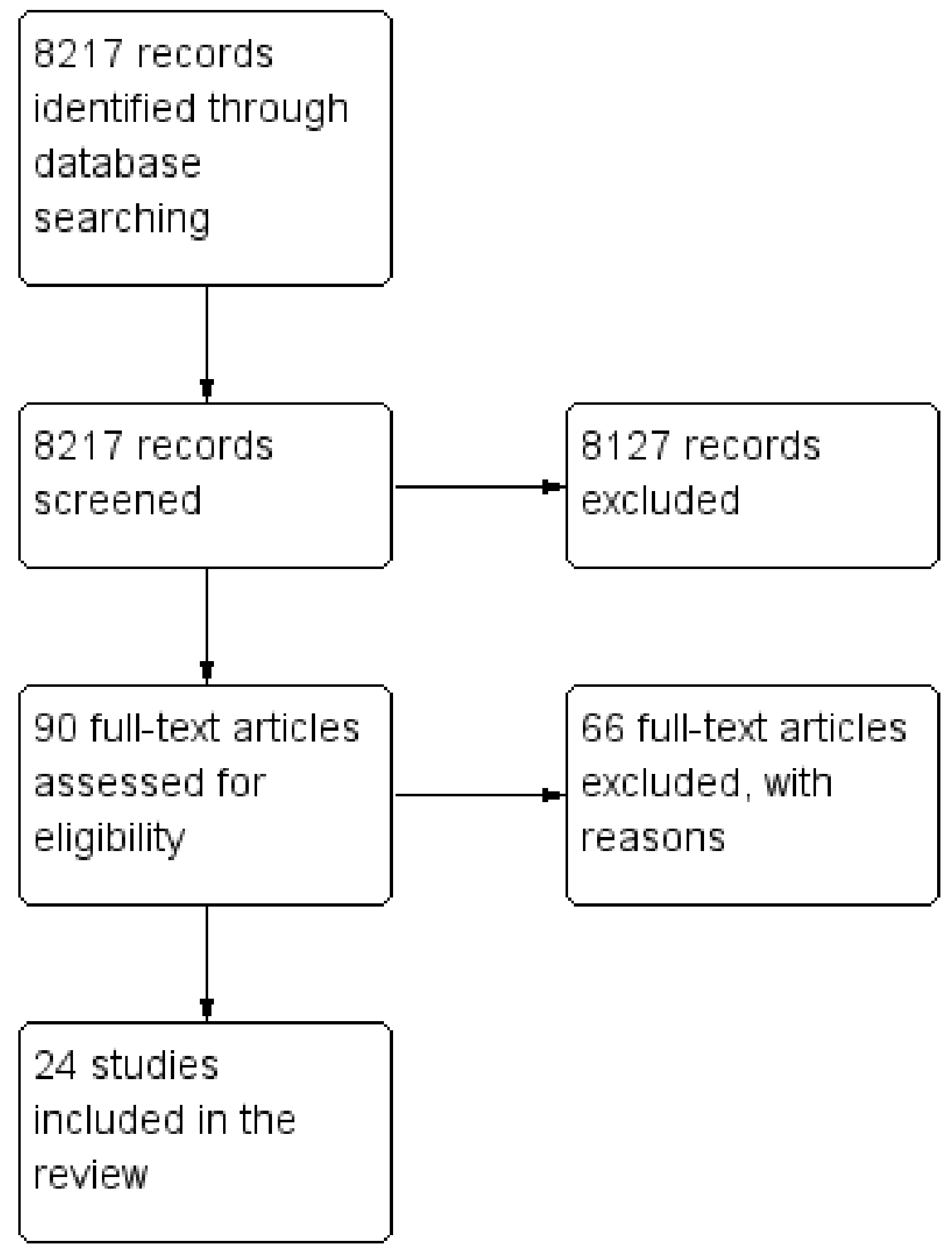

\section{First update}

The updated searches spanned from October 2004 until March 2013. This identified a total of 3896 records after duplication. We acquired a total of 115 full text papers for assessment and excluded 105 papers, bringing 10 new trials to the review (see Figure 2). 
Figure 2. Study flow diagram of paper selection: First Update

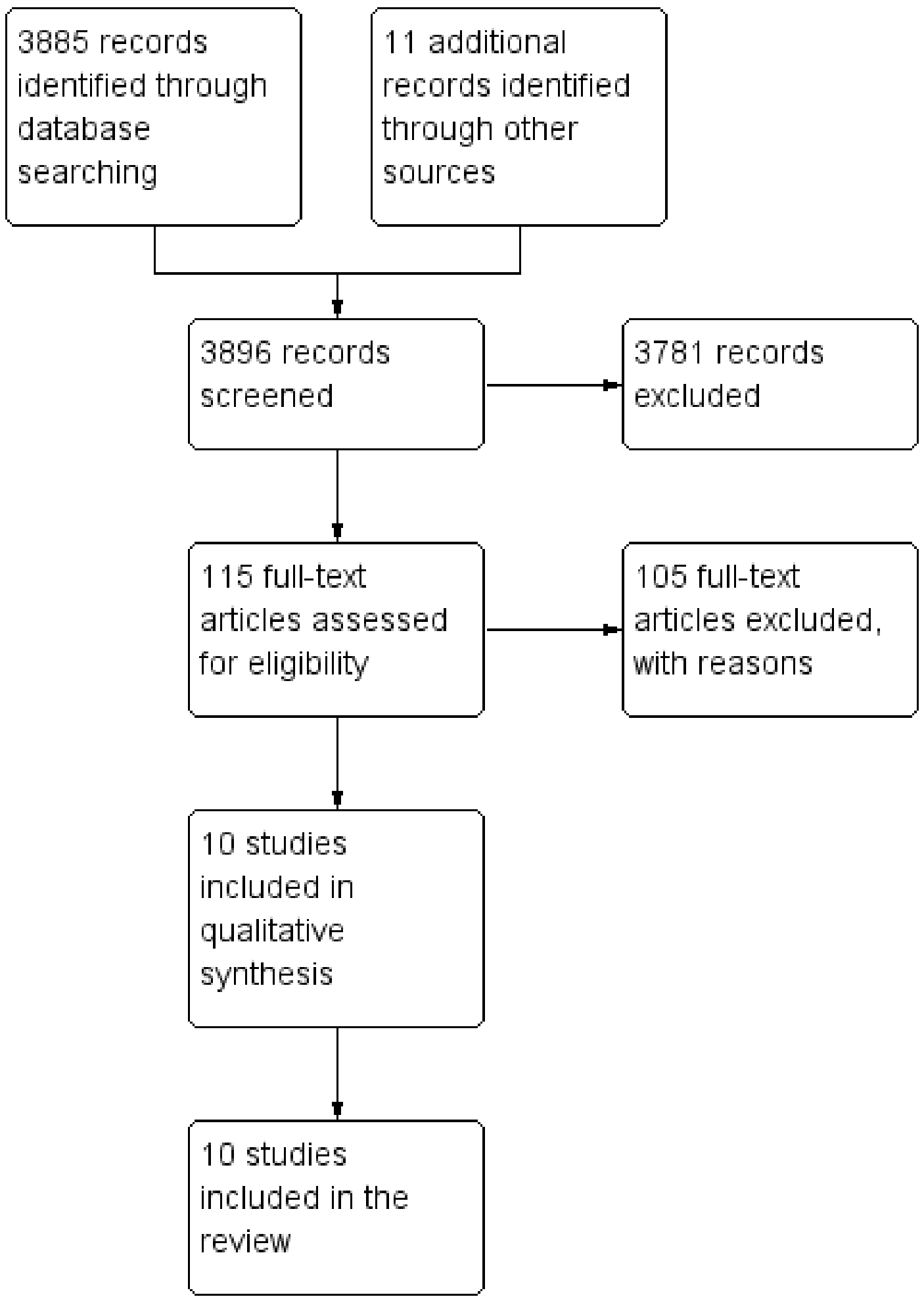




\section{Second update}

The updated searches spanned from March 2013 until May 2014. This identified a total of 2092 records after duplication. We acquired a total of 72 full text papers for assessment and excluded 68 papers, bringing four new trials to the review making a total of 14 trials (see Figure 3). 
Figure 3. Study flow diagram of paper selection: Second Update

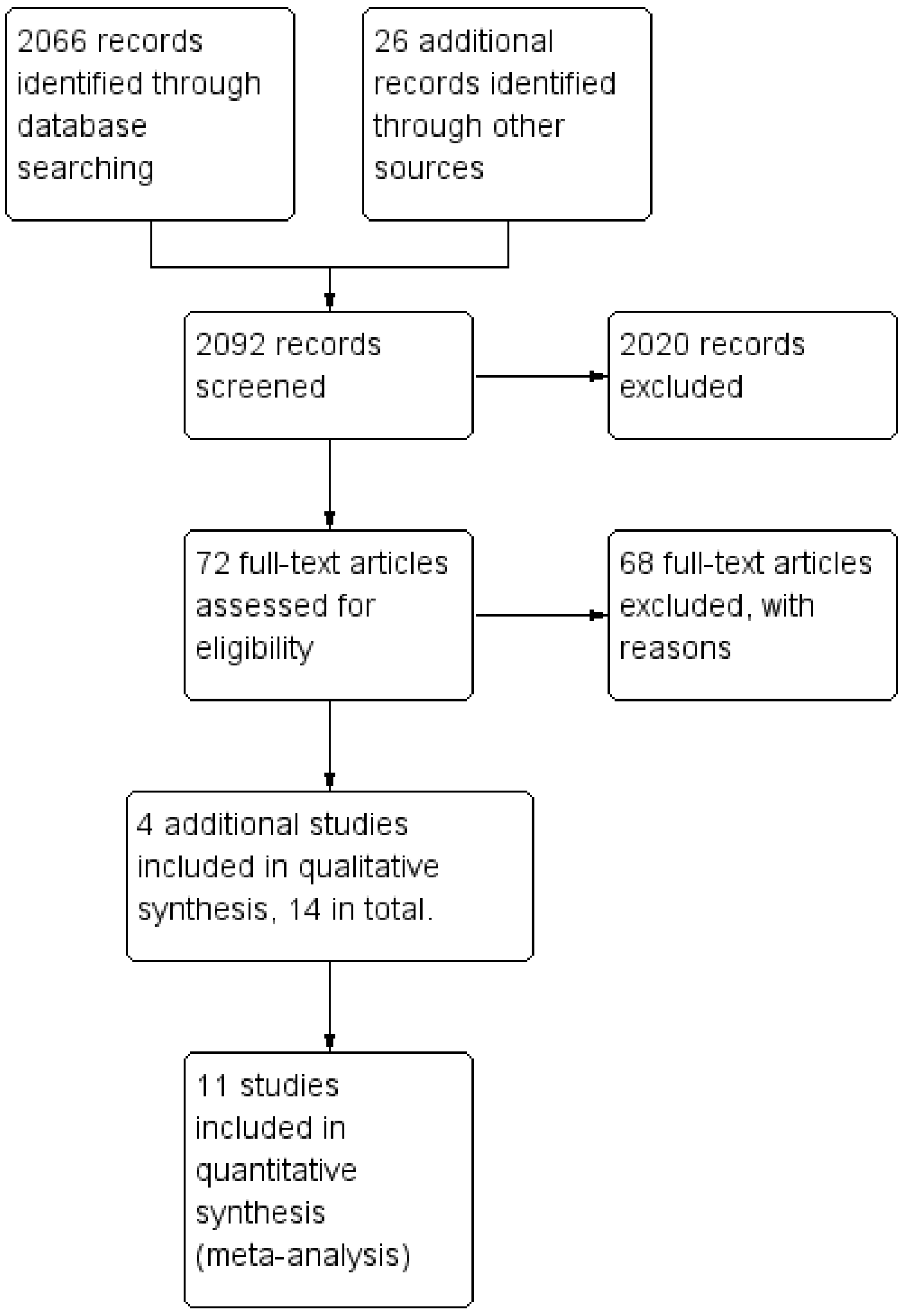




\section{Included studies}

- The studies were published between 1969 and 2014 and represented 14 trials, including 2647 participants. The 14 trials consisted of 18 trial publications on different interventions (Bayanzadeh 2004; Brown 2013; Cornish 1997; Cropsey 2011; Coviello 2010; Dolan 2003; Dole 1969; Howells 2002; Kinlock 2005; Kinlock 2007; Lobmaier 2010; Lobmann 2007; Magura 2009; Wright 2011). Two trials represented data from multiple follow-up publications. The Dolan studies published data on the primary study and four year follow-up data (Dolan 2003); and Kinlock and colleagues reported on outcome measures and a secondary analysis of the data in two subsequent publications (see Kinlock 2007). See Table 1 for a summary of study information and outcomes.

- A number of studies produced different comparisons and were combined appropriately according to time point of measurement (e.g. 1 month, 3 months, 6 months, 12 months) and type of outcome.

\section{Treatment regimens and settings}

- Thirteen studies used methadone as the intervention or for comparison (Bayanzadeh 2004; Brown 2013; Dolan 2003; Dole 1969; Howells 2002; Kinlock 2005; Kinlock 2007; Lobmaier 2010; Lobmann 2007; Magura 2009; Wright 2011). Brown 2013 compared specialist treatment plus suboxone or methadone versus primary care plus suboxone; Lobmann 2007 compared methadone with diamorphine; and Magura 2009 and Wright 2011 compared methadone with buprenorphine. One study compared methadone to lofexidine (Howells 2002). All other studies compared methadone maintenance with interventions where there was no drugs administration (waiting list or counselling alone).

- Three studies used naltrexone in oral and implantation formats in comparison with probation or parole (Cornish 1997); psychosocial therapy (Coviello 2010); and methadone (Lobmaier 2010).

- One study compared the use of buprenorphine with a placebo (Cropsey 2011).

- The studies were categorised by setting; five studies were conducted in the community (Cornish 1997; Lobmann 2007; Coviello 2010; Cropsey 2011; Brown 2013); and the remainder in secure settings (Dole 1969; Dolan 2003; Bayanzadeh 2004; Kinlock 2005; Kinlock 2007; Magura 2009; Lobmaier 2010; Howells 2002; Wright 2011).
- One study was conducted using a jail diversion scheme for either a drug treatment court or Treatment Alternative Program (TAP) (Brown 2013).

- Different outcome measures were presented for each study, and just over half of all studies reported four or more outcome measures (see Table 1). Criminal justice and drug outcomes were measured by all studies except four. Cornish 1997 and Lobmann 2007 reported on criminal activity outcomes only; and Bayanzadeh 2004, Brown 2013, Dolan 2003, Cropsey 2011 and Wright 2011 reported on drug use only.

\section{Countries in which the studies were conducted}

- Nine studies were published in the US, two in England, one in Iran, one in Australia, one in Norway and one in Germany.

\section{Duration of trials}

- Most studies $(n=10)$ reported outcomes of six months or less, and the longest follow-up period was four years.

\section{Participants}

- The fourteen studies included adult drug-using offenders: twelve of the fourteen studies used samples with a majority of men and one study used female offenders only (Cropsey 2011). In two studies, gender was not reported (Lobmann 2007; Wright 2011).

- The average age of study participants ranged from 27 years to 40.9 years.

\section{Excluded studies}

We excluded 165 studies. See Characteristics of excluded studies for further details. Reasons for exclusion were: lack of criminal justice involvement in referral to the intervention; not reporting relevant drug or crime outcome measures or both at both the preand post-intervention periods; allocation of participants to study groups that were not strictly randomised or did not contain original trial data. The majority of studies were excluded because the study population were not offenders. One study was excluded because follow-up periods were not equivalent across study groups (Di Nitto 2002); and Berman 2004 was excluded because the intervention (acupuncture) did not measure our specified outcomes of drug use or criminal activity. One study reported the protocol of a trial only (Baldus 2011); while another only contained conference proceedings (Kinlock 2009a). We were unable to obtain the data for one trial (Cogswell 2011); or the full-text version of another (Rowan-Szal 2005).

\section{Risk of bias in included studies}

See Figure 4 and Figure 5 for further information.

Pharmacological interventions for drug-using offenders (Review) 
Figure 4. Risk of bias graph: review authors' judgements about each risk of bias item presented as percentages across all included studies.

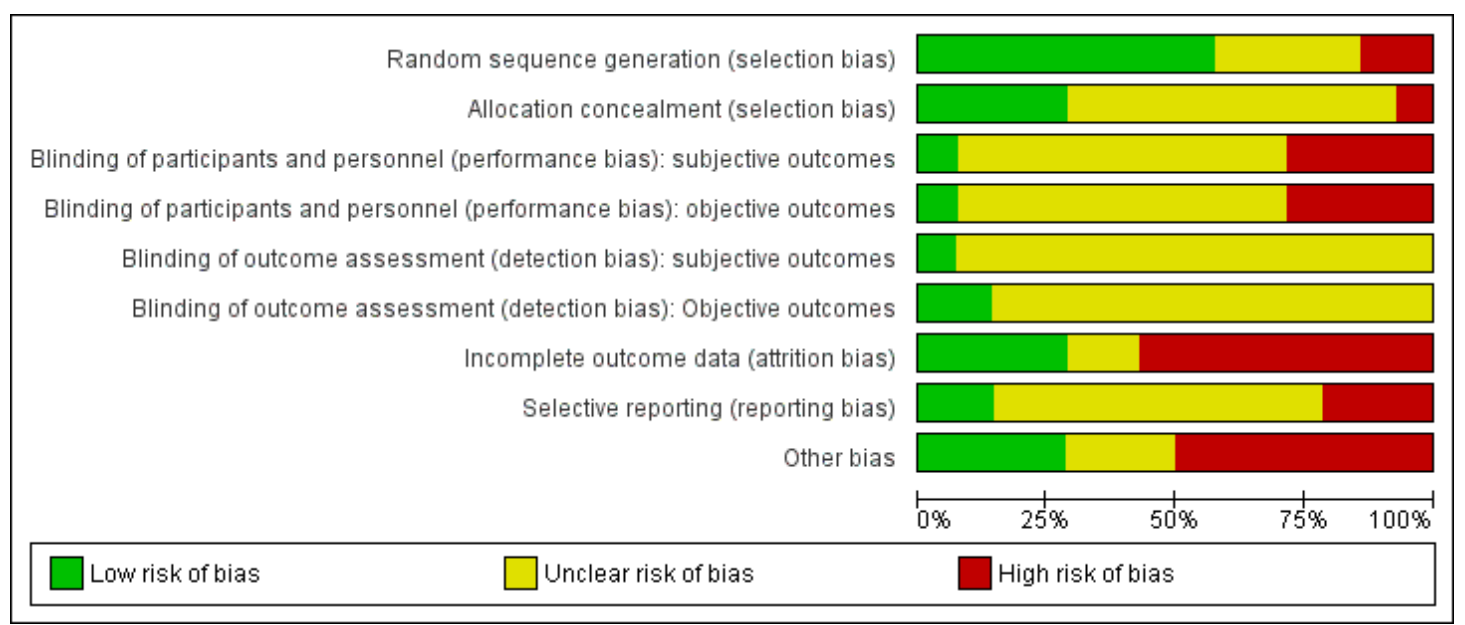


Figure 5. Risk of bias summary: review authors' judgements about each risk of bias item for each included study.

\begin{tabular}{|c|c|c|c|c|c|c|c|c|c|}
\hline & 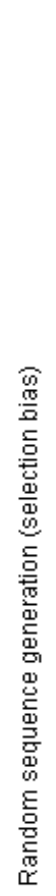 & 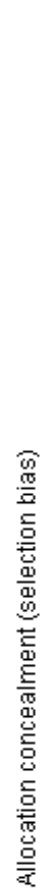 & 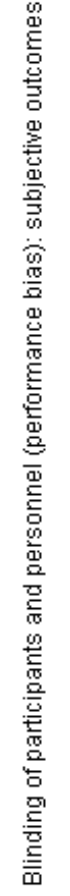 & 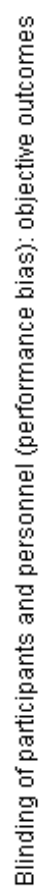 & 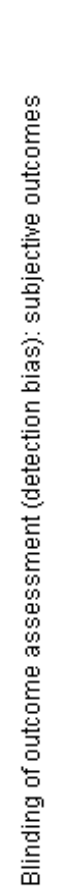 & 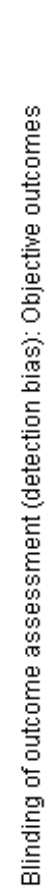 & 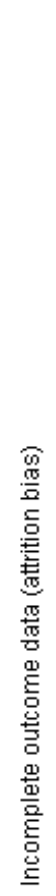 & 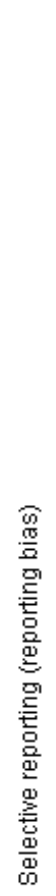 & 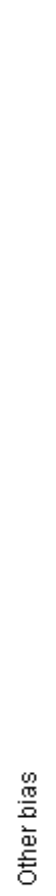 \\
\hline Bayanzadeh 2004 & $\Theta$ & $?$ & $?$ & $?$ & $?$ & $?$ & - & $?$ & - \\
\hline Brown 2013 & $?$ & $?$ & $?$ & $?$ & $?$ & $?$ & $\theta$ & O & $\Theta$ \\
\hline Cornish 1997 & $\odot$ & $?$ & - & $\odot$ & $?$ & + & + & $?$ & $?$ \\
\hline Coviello 2010 & $?$ & $?$ & $\theta$ & $\theta$ & $?$ & $?$ & $\theta$ & $?$ & $\theta$ \\
\hline Cropsey 2011 & $\Theta$ & $\odot$ & $?$ & $?$ & $?$ & $?$ & $?$ & $?$ & $\oplus$ \\
\hline Dolan 2003 & + & $\odot$ & $?$ & $?$ & $?$ & $?$ & $\theta$ & + & + \\
\hline Dole 1969 & $\odot$ & $?$ & $?$ & $?$ & $?$ & $?$ & + & $?$ & $?$ \\
\hline Howells 2002 & $?$ & $?$ & + & $\odot$ & + & + & $\theta$ & + & $\Theta$ \\
\hline Kinlock 2005 & $?$ & $?$ & $?$ & $?$ & $?$ & $?$ & $\theta$ & - & $\Theta$ \\
\hline Kinlock 2007 & $\odot$ & $?$ & $?$ & $?$ & $?$ & $?$ & $\theta$ & $?$ & $\theta$ \\
\hline Lobmaier 2010 & + & + & 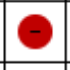 & $\odot$ & $?$ & $?$ & + & $?$ & + \\
\hline Lobmann 2007 & $\odot$ & $?$ & $?$ & $?$ & $?$ & $?$ & + & $?$ & $?$ \\
\hline Magura 2009 & + & $\Theta$ & $?$ & $?$ & $?$ & $?$ & $?$ & $?$ & $\Theta$ \\
\hline Wright 2011 & $\odot$ & $\odot$ & - & $\odot$ & $?$ & $?$ & $\Theta$ & 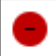 & $\odot$ \\
\hline
\end{tabular}




\section{Allocation}

Randomisation: All of the 14 included studies were described as randomised. In four studies, the reporting of this information was noted as unclear, as it was difficult to find an accurate description of the methodology used (Brown 2013; Coviello 2010; Howells 2002; Kinlock 2005). Two studies were reported at high risk of bias (Bayanzadeh 2004; Cropsey 2011); and the remaining eight studies at low risk of bias.

Allocation concealment: Of the 14 included studies, only four reported that the allocation process was concealed and were rated at low risk of bias (Cropsey 2011; Dolan 2003; Lobmaier 2010; Wright 2011). One study was rated at high risk of bias (Magura 2009). All of the remaining nine studies were rated as unclear, and the review author was not able to decide whether allocation concealment had occurred within the studies.

\section{Blinding}

Blinding was assessed across four dimensions considering performance and detection bias across subjective and objective measures (see Appendix 14). Nine studies were rated as unclear risk of bias providing no information on blinding across all four domains (Bayanzadeh 2004; Brown 2013; Cropsey 2011; Dolan 2003; Dole 1969; Kinlock 2005; Kinlock 2007; Lobmann 2007; Magura 2009). Four studies were rated at high risk of bias for participant and personnel blinding (Cornish 1997; Coviello 2010; Lobmaier 2010; Wright 2011). Cornish 1997 was rated at low risk of outcome assessors on objective measures.

\section{Incomplete outcome data}

Four studies were noted at low risk of bias (Cornish 1997; Dole 1969; Lobmaier 2010; Lobmann 2007); eight studies were noted at high risk of bias; and two studies were rated as unclear (Cropsey 2011; Magura 2009).

\section{Selective reporting}

Of the 14 studies, nine studies were rated as unclear, and two studies were rated at low risk (Dolan 2003; Howells 2002). Three studies were rated at high risk of bias (Brown 2013; Kinlock 2005; Wright 2011).

\section{Other potential sources of bias}

Threats to other bias within the study designs generally yielded mixed results. In total, seven studies were rated at high risk. Low risk was noted in four further studies (Cropsey 2011; Dolan 2003; Lobmaier 2010; Wright 2011); and three studies were rated as unclear (Cornish 1997; Dole 1969; Lobmann 2007).
See Figure 4 and Figure 5 for additional details.

\section{Effects of interventions}

See: Summary of findings for the main comparison Summary of findings for the main comparisons: Agonist pharmacological compared to no intervention for drug-using offenders; Summary of findings 2 Summary of findings for the main comparisons: Antagonost (Naltrexone) compared to no pharmacological for drug-using offenders

Of the 14 studies, 11 were included in a series of meta-analyses and the main comparisons are presented in the 'Summary of findings' tables (Summary of findings for the main comparison; Summary of findings 2). Three studies were not included in the meta-analyses: Bayanzadeh 2004 because it compared methadone + CBT versus not further specified non-pharmacological treatment, so it was not possible to ascertain the effect of methadone treatment alone; Brown 2013 because it compared specialist treatment plus suboxone or methadone versus primary care plus suboxone, so it was not possible to ascertain the effect of methadone or suboxone alone; moreover it did not assess the outcomes of interest; and Howells 2002 because it did not assess the outcomes of interest and repeated attempted contact with the authors asking for more information was unsuccesful. For those studies that were included we grouped them by drug and criminal activity outcomes (re-arrest and reincarceration), setting (community and secure establishment), and intervention type (buprenorphine, methadone and naltrexone). Tests for heterogeneity at the 0.01 level revealed that across all meta-analyses, the studies were found to be homogeneous.

\section{Agonist pharmacological interventions vs no non- pharmacological treatment}

\section{Drug use}

See Summary of findings for the main comparison

For dichotomous measure, results did not show reduction in drug use for objective results (biological), two studies, 237 participants: (RR $0.72,95 \%$ CI 0.51 to 1.00 ), low quality of evidence and for subjective (self-report), three studies, 317 participants: (RR 0.61 $95 \%$ CI 0.31 to 1.18 ), low quality of evidence. Also for continuous measures, self-report drug use did not show differences, three studies, 510 participants: (SMD -0.62 95\% CI -0.85 to -0.39), low quality of evidence, see Analysis 1.1; Analysis 1.2; and Analysis 1.3 .

\section{Criminal activity}

See Summary of findings for the main comparison

All data come from studies assessing the efficacy of methadone treatment. Both for reincarceration three studies, 472 participants (RR $0.77,95 \%$ CI 0.36 to 1.64 ) low quality of evidence; and re-

Pharmacological interventions for drug-using offenders (Review) 
arrests, one study, 62 participants (RR 0.60, 95\% CI 0.32 to 1.14 ), low quality of evidence, the studies did not show difference (see Analysis 1.4). The impact on criminal activities was evaluated also utilising continuous measures in one study, 51 participants: MD of -74.21 (95\% CI -133.53 to -14.89), low quality of evidence, the result is in favour of pharmacological interventions, (see Analysis $1.5)$.

\section{Antagonist (Naltrexone) pharmacological treatment vs non -pharmacological treatment?}

See Summary of findings 2

Two studies, 114 participants focused on the use of naltrexone versus no pharmacological treatment and subsequent criminal activity. The results indicate that naltrexone does appear to reduce subsequent reincarceration, with an RR of 0.40 (95\% CI 0.21, $0.74)$, moderate quality of evidence, see Analysis 2.1

One study, 63 participants (RR 0.69, 95\% CI 0.28 to 1.70) did not show statistically significant difference, low quality of evidence, see Analysis 2.2,

\section{Methadone versus buprenorphine}

\section{Drug use}

Two studies (Magura 2009; Wright 2011), showed a reduction in self report drug use for 370 participants using a dichotomous outcome (RR 1.04. 95\% CI 0.69 to 1.55 ) altough the result is not statistically significant. Continuous outcomes, one study with 81 participants, (MD 0.70, 95\% CI -5.33 to 6.73 ) see Analysis 3.1 and Analysis 3.2.

\section{Criminal activity}

Magura 2009 showed a non-statistically significant reduction in criminal activity for 116 participants (RR 1.25 , 95\% CI 0.83 to 1.88) see Analysis 3.3.

\section{Methadone versus diamorphine}

Drug use: the study did not assess this outcome

\section{Criminal activity}

Rearrest: One study, (Lobmann 2007) 825 participants shows a non-statistically significant reduction in criminal activity for rearrests: (RR 1.25, 95\% CI 1.03 to 1.51 see Analysis 4.1.

\section{Methadone vs naltrexone}

Drug use

Lobmaier 2010, 44 participants, showed a non-statistically significant reduction in self reported drug use continuous MD 4.60 (95\% CI -3.54 to 12.74 ) see Analysis 5.1.

\section{Criminal activity}

Lobmaier 2010, 44 participants, showed a non-statistically significant reduction in dichotomous reincarceration, outcomes (RR $1.10,95 \%$ CI 0.37 to 3.26) and continuous outcomes (MD -0.50, $95 \%$ CI -8.04 to 7.04 ) see Analysis 5.2; Analysis 5.3.

\section{Does setting of intervention (community, prison/secure establishment) affect outcomes of pharmacological interventions?}

All the studies comparing methadone versus non-pharmacological intervention were conducted in a secure setting; the only study comparing buprenorphine with non-pharmacological intervention was conducted in the community, as well as the two studies comparing naltrexone with non-pharmacological treatment. In the other comparison only one study was included for each, so it was not possible to perform a subgroup analysis for setting of the intervention.

\section{Cost and cost-effectiveness}

The Magura study noted differences in the costs of administering buprenorphine and methadone, but were not sufficient for us to conduct a full cost effectiveness appraisal (Magura 2009). The investigators estimated that about ten times as many inmates can be served with methadone as with buprenorphine with the same staff resources. This cost implication is also endorsed in the community, where physicians have difficulty in obtaining reimbursement for buprenorphine treatment for released inmates, making the continued use of buprenorphine problematic after release. 


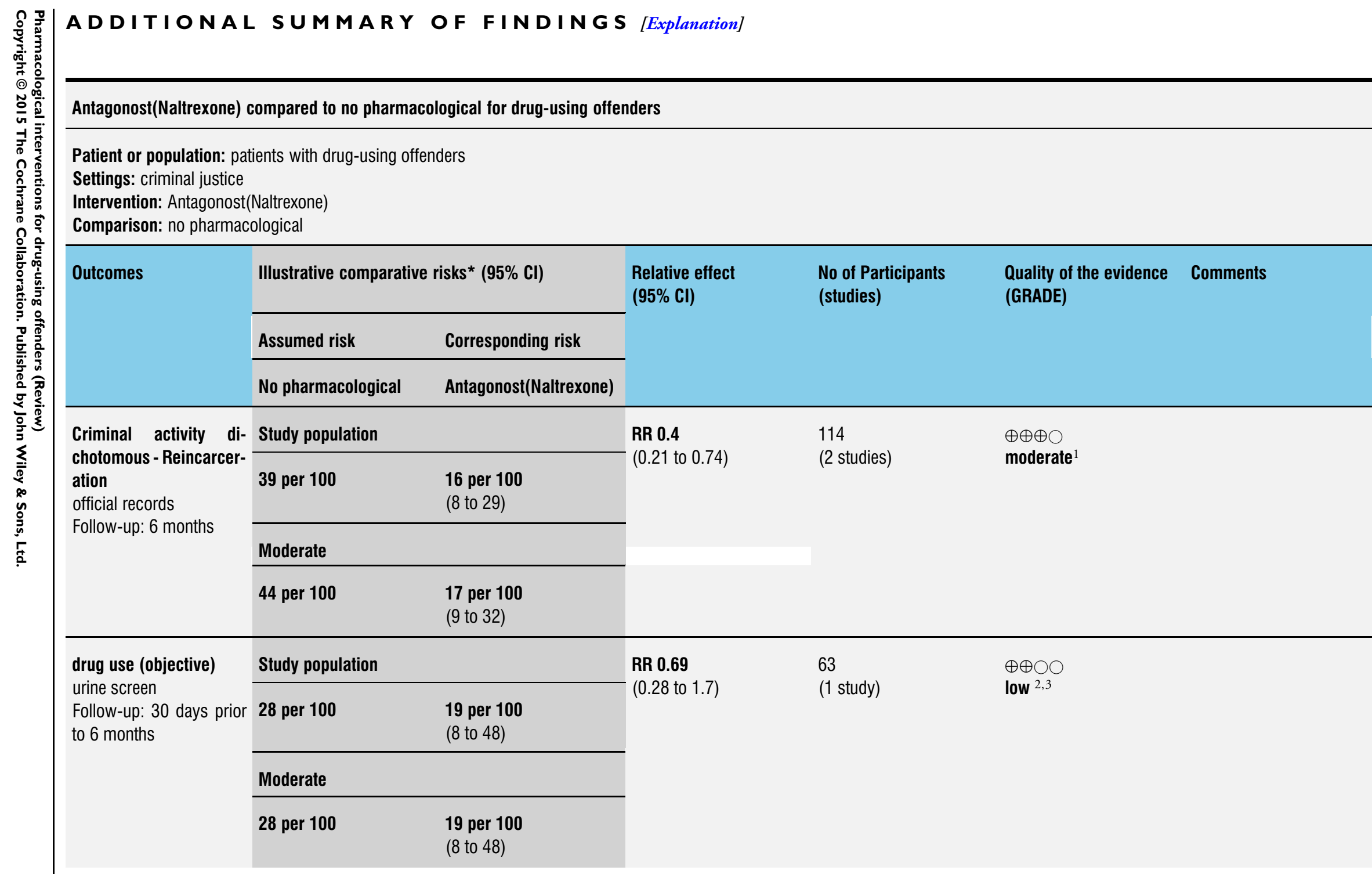


*The basis for the assumed risk (e.g. the median control group risk across studies) is provided in footnotes. The corresponding risk (and its $95 \%$ confidence interval) is based on the assumed risk in the comparison group and the relative effect of the intervention (and its $95 \% \mathrm{Cl}$ ).

Cl: Confidence interval; RR: Risk ratio;

GRADE Working Group grades of evidence

High quality: Further research is very unlikely to change our confidence in the estimate of effect.

Moderate quality: Further research is likely to have an important impact on our confidence in the estimate of effect and may change the estimate.

Low quality: Further research is very likely to have an important impact on our confidence in the estimate of effect and is likely to change the estimate.

Very low quality: We are very uncertain about the estimate.

Across the two studies 9 of the 18 risk of bias items were rated as unclear

25 of the 9 risk of bias items was rated as unclear

3 only 1 study with 63 participants 


\section{DISCUSSIO N}

\section{Summary of main results}

This systematic review provides evidence from 14 trials producing several meta-analyses. Studies could not be combined all together because the comparisons were too different. Only subgroup analysis for type of pharmacological treatment was done. Findings of the effects of individual interventions on drug use and criminal activity show mixed results. When compared to non-pharmacological, we found low quality evidence that agonist treatments are not effective in reducing drug use or criminal activity. We found low quality of evidence that antagonist treatment was not effective in reducing drug use but we found moderate quality of evidence that they significantly reduced criminal activity. When comparing the drugs to one another we found no significant differences between the drug comparisons (methadone versus buprenorphine, diamorphine and naltrexone) on any of the outcome measures suggesting that no one pharmacological drug is more effective than another. Two studies provided some cost comparisons, but data were not sufficient to generate a cost-effectiveness analysis. In conclusion, we found that pharmacological interventions do reduce subsequent drug use and (to a lesser extent) criminal activity. Additionally, we found individual differences and variation on different outcome measures when pharmacological interventions were compared to a non-pharmacological treatment but no significant differences when compared to another pharmacological treatment.

\section{Buprenorphine}

The Cropsey study specifically evaluated buprenorphine for opioid-dependent women with HIV risk and found that buprenorphine given to participants in prison (followed by its use upon release into the community) was beneficial in preventing or delaying relapse to opioid use (Cropsey 2011). The findings of this study add to the growing body of evidence (which primarily includes men) suggesting that outcomes with buprenorphine are comparable with what others have found with both methadone and methadone maintenance (Lobmaier 2010). The findings however were not sustained post treatment, and most women had relapsed to active opioid treatment at the three-month follow-up point. Future studies on the use of buprenorphine in women should evaluate its impact on long-term effects with the goal of assessing its effect on opioid abstinence and prevention of associated criminal activity (Cropsey 2011). Overall, the dosage of buprenorphine varied between studies; in one study, instances of $30 \mathrm{mg}$ rising to $130 \mathrm{mg}$ were reported (Lobmaier 2010). A meta-analysis of buprenorphine dose and treatment outcome found that a higher dosage (16 to $32 \mathrm{mg}$ per day) predicted better retention in treatment when compared with a lower dosage (Fareed 2012). Another Cochrane review (outside the prison environment) indicated that buprenorphine detoxification and maintenance studies concluded that completion of withdrawal treatment is possibly more likely when managed with buprenorphine compared to methadone although the difference was not statistically significant, leading the authors to conclude that more research is needed to evaluate the possible differences between the two medications (Gowing 2009). The Wright 2011 study in this review suggests that there is equal clinical effectiveness between buprenorphine and methadone in maintaining abstinence at eight days post detoxification in prison. As many prisoners are eventually released back into the community the authors note that GPs need to be aware of the few trials which compare two of the most common detoxification agents in the UK. The research currently supports the use of either buprenorphine or methadone within a detoxification setting (Wright 2011).

\section{Methadone}

Two studies showed a decrease in self-report methadone treatment upon release into the community (Dole 1969; Magura 2009). The Dole study, albeit small, found that 3 of 12 prisoners who started using methadone before release were convicted of new crimes during an 11.5-month follow-up compared with 15 of 16 prisoners randomly assigned to a control condition (Dole 1969); and a larger, more recent study found that Rikers Island MMT programme in New York significantly facilitated entry and retention at six months in post release programmes (Magura 2009). In contrast, another study reported on opioid agonist maintenance by examining levo-alpha-acetylmethadol (LAAM) before prison release and found no significant differences with regard to subsequent arrest of participants who received LAAM and a control group at nine months post-release (Kinlock 2005). Subsequent Kinlock studies involving evaluations of counselling only and counselling with transfer in comparison with counselling and methadone support the findings of Dole 1969 and Dolan 2003 suggesting that methadone programmes can provide effective opioid agonist therapy for prisoners with a history of heroin addiction but not arrest at 12 month post prison release (Kinlock 2007). Taken together, the findings also suggest that increased criminal activity and overdose death are disproportionately likely to occur within one month of release from incarceration. The authors conclude that making connections with drug treatment services at release from prison is likely to help sustain treatment for opiod addictions; such findings are supported by other studies which found that offering prerelease MMT and payment assistance was significantly associated with increased enrolment in post-release MMT and reduce time to enter community-based MMT (e.g. Binswanger 2007). Additionally, in support of methadone treatment, the World Health Organisation has listed methadone as an essential medication and has strongly recommended that treatment should be made available in prison and supported subsequently within the community to significantly reduce the likelihood of adverse health and criminogenic consequences (Hergert 2005).

Dosage of methadone treatment varied across studies. For example, Magura 2009 reported problems with the use of suboptimal doses of methadone when higher doses were available. Investigators argue that higher doses appear to reflect participant preference 
because most did not intend to continue treatment after release. The Dolan study reported moderate doses of methadone $(61 \mathrm{mg}$ ) and noted that outcomes might have improved if higher doses had been given (Dolan 2003). Significantly lower doses of methadone were noted in the Dole study, in which $10 \mathrm{mg}$ of methadone per day was increased to a dosage of $35 \mathrm{mg}$ per day (Dole 1969). Participants in the Kinlock 2005 study were medicated three times per week, starting at $10 \mathrm{mg}$ and increasing by $5 \mathrm{mg}$ every third medication day during incarceration to a target dose of $50 \mathrm{mg}$. Evidence from the Amato 2005 review suggests that low dosages of methadone maintenance lead to compromise in the effectiveness of treatment and that recommendations for dosage should be monitored at around $60 \mathrm{mg}$. Additional systematic review evidence considering the use of methadone and a tapered dose for the management of opioid withdrawal shows a wide range of programmes with differing outcome measures, making the application of meta-analysis difficult (Amato 2013). The authors conclude that slow tapering with temporary substitution of long-acting opioids can reduce withdrawal severity; however, most participants still relapsed to heroin use (Amato 2013).

\section{Naltrexone}

For evaluation of naltrexone, two studies (one pilot: Cornish 1997) and Coviello 2010, a subsequent larger replication trial, show that use of a larger sample size consisting of a diverse group of offenders resulted in no differences in criminal behaviour between naltrexone and treatment-as-usual groups. The authors note that one of the major differences between the two studies remains the extent and quality of supervision provided by parole officers. The authors suggest that for treatment to be successful, use of oral naltrexone by probationers and parolees requires more supervision than is typically available within the criminal justice system. Study authors reported instances of $35 \mathrm{mg}$ of naltrexone rising to $300 \mathrm{mg}$ (Coviello 2010). Other research evidence related to naltrexone use and mortality rates highlights possible concerns about the high risk of death after treatment. Gibson 2007 compared mortality rates associated with naltrexone and methadone by using retrospective data analysis of coronial participants between 2000 and 2003. Findings show that participants receiving naltrexone were up to 7.4 times more likely to die after receiving treatment when compared with those using methadone over the same time period. Although this study was not conducted in a population of prisoners, it is likely that such risks are comparable; therefore generalised use of naltrexone and associated subsequent supervision of those taking naltrexone in its oral form require careful consideration.

\section{Overall completeness and applicability of evidence}

Overall, the findings of this review suggest that pharmacological interventions have an impact on reducing self-report drug use. Individual pharmacological drugs had differing effects, particularly in relation to subsequent drug use. Promising results highlight the use of methadone or buprenorphine (although this was only one study) within a prison environment but may be limited to shorterterm outcomes when prisoners are released into the community. For naltrexone, the evidence is sparse and presents problems associated with different mechanisms of drug administration (e.g. oral versus implants). We can say little about the cost and cost-effectiveness of these studies. One study reported some descriptive cost information, but the information was insufficient to generate a cost analysis (Magura 2009). In conclusion, high-quality research is required to evaluate the processes involved in the engagement of offenders mandated to substance abuse programmes to enable us to understand better why one programme works and another does not.

\section{Quality of the evidence}

A number of limitations within each of the studies are highlighted by the authors. High dropout rates were noted in the methadone group after prison release in the Lobmaier study and appear to be more difficult to maintain in offender populations (Lobmaier 2010). Major limitations of the Coviello 2010 study included low treatment retention and low six-month follow-up rates. Most offenders did not return for the follow-up evaluation because they could not be located (63\%). Only two-thirds of treated participants remained in treatment in the Dolan study (Dolan 2003). As a consequence, the study does not provide conclusive evidence regarding the efficacy of oral naltrexone in this offender sample. Attrition was also a problem in Kinlock 2005; this was due in part to the fact that individuals were being transferred to other prisons or were having their sentences extended because of preexisting charges (Kinlock 2005). Similiar problems of segregation and impact of sentence releases affected the sample size in the Bayanzadeh 2004 and Wright 2011 studies whereby transfer to other prison establishments with little prior warning made followup data difficult to collect. Such attrition within studies threatens the comparability of experimental and control groups, thereby ensuring that any conclusions should be taken with considerable caution. In particular, the Bayanzadeh 2004 study noted some of the practical difficulties associated with contamination between experimental and control groups, given that the ideal would be to keep the groups apart. In contrast the pilot study by Brown 2013 produced a study retention rate of $80 \%$; the authors note that this may be due to the coercive nature of participation in jail diversion programs in which successful completion may result in the dismissal or reduction of criminal charges. Although this finding is represented by only one study it suggests the possibility that completion of drug treatment programs might fare best when an incentive which effects sentence or charge outcome can be sustained.

Sample sizes were considered modest in a number of studies, with attrition presenting difficulties in interpretation of study findings. For example, $30 \%$ attrition at follow-up producing possible threats 
to the internal validity of the study design in Magura 2009 and similar small sample sizes in the Lobmaier trial may have been too small to reveal any differences between the two treatment conditions (Lobmaier 2010). The Cropsey 2011 study identified a sample of 36 women and randomly allocated 15 to the intervention and 12 to the placebo group. Investigators note that although the potency of buprenorphine for control of opioid use is clearly demonstrated, a larger sample size may be needed to detect significant differences between groups on other variables of interest. Larger trials are therefore required to assess the possible advantages of one treatment over the other. Additionally, the study was limited to three months of treatment, and further studies should explore the provision of buprenorphine for longer periods of time to prolong opioid abstinence and prevent associated criminal activity. Similiar short follow-up periods were noted in other trials, including Dolan 2003.

\section{Potential biases in the review process}

Despite limitations associated with the literature, two limitations in review methodology were achieved. Specifically, the original review included an additional five fee paying databases and one search using DrugScope. In this current review resources did not allow such extensive searching. Whislt the electronic databases searches have been updated to April 2014. the web site search has been updated to November 2011. As a result some literature may have been missed from this current review

\section{AUTHORS' CONCLUSIONS}

\section{Implications for practice}

When compared to non-pharmacological treatments, agonist treatments did not seem effective in reducing drug use or criminal activity Antagonist treatment was not effective in reducing drug use but significantly reduced criminal activity. When comparing the drugs to one another we found no significant differences between the drug comparisons (methadone versus buprenorphine, diamorphine and naltrexone) on any of the outcome measures. Caution should be taken when interpreting these findings, as the conclusions are based on a small number of trials, and generalisation of these study findings should be limited mainly to male adult offenders. Additionally, many studies were rated at high risk of bias because trial information was inadequately described.

\section{Implications for research}

Several research implications can be identified from this review.

1. Generally, better quality research is required to evaluate the effectiveness of interventions with extended long-term effects of aftercare following release into the community.

2. Buprenorphine research in the prison environment requires evidence of the long-term impact and larger studies, currently an equivalence of buprenorphine and methadone exists.

3. Evidence for naltrexone is less convincing. Trials evaluating differences between oral and implantation naltrexone and associated supervision requirements under the criminal justice system are required.

4. Only one court diversion study was identified: exploration of some court diversionary schemes using different pharmacological interventions would be useful.

5. Future clinical trials should collect information from all sectors of the criminal justice system. This would enhance the heterogeneous nature of the included studies and would facilitate generalisation of study findings.

6. Evidence of comparable mortality rates in prisoners using pharmacological interventions (particularly after release) needs to be explored to assess the long-term outcomes of such treatments.

7. The link between dosage, treatment retention and subsequent criminal activity should be examined across all three pharmacological treatment options. Evidence from other trial data suggests that dose has important implications for retention in treatment; in future studies, this should be considered alongside criminal activity outcomes.

8. Cost and cost-effectiveness information should be standardized within trial evaluations; this will help policymakers to decide upon health versus criminal justice costs.

\section{ACKNOW LEDGEMENTS}

We would like to acknowledge the help of the York Health Economics Consortium and The Health Sciences Department at the University of York and the Cochrane Drugs and Alcohol Group. 


\section{R E F E R E N C E S}

\section{References to studies included in this review}

Bayanzadeh 2004 \{unpublished data only\}

Bayanzadeh SA. Final report of research project: a study of the effectiveness of psychopharmacological and psychological interventions in reducing harmful/high risk behaviours among substance user prisoners. Iran University of Medical Education and Health and Treatment Services, Tehran Psychology Institute. Centre for Psychological Health Research Polarity of Science, Education and Research 2004.

Brown 2013 \{published data only\} Brown R, Gassman M, Hetzel S, Berger L. Communitybased treatment for opioid dependent offenders: A pilot study. American Journal on Addictions 2013;22(5):500-2.

Cornish 1997 \{published data only\}

* Cornish JW, Metzger D, Woody GE, Wilson D, McLellan AT, Vandergrift B, et al. Naltrexone pharmacotherapy for opioid dependent federal probationers. Journal of Substance Abuse Treatment 1997;14(6):529-34.

Coviello 2010 \{published data only\}

Coviello DM, Cornish JW, Lynch KG, Alterman AI, O'Brien CP. A randomized trial of oral naltrexone for treating opioid-dependent offenders. American Journal of Addiction 2010;19(5):422-32.

Cropsey 2011 \{published data only\}

Cropsey KL, Lane PS, Hale GJ, Jackson DO, Clark CB, Ingersoll KS, et al. Results of a pilot randomized controlled trial of buprenorphine for opioid dependent women in the criminal justice system. Drug and Alcohol Dependence 2011; 119(3):172-8.

Dolan 2003 \{published data only\}

* Dolan K A, Shearer J, MacDonald M, Mattick RP, Hall

W, Wodak AD. A randomised controlled trial of methadone maintenance treatment versus wait list control in an Australian prison system. Drug and Alcohol Dependence 2003;72(1):59-65.

Dolan KA, Shearer J, White B, Zhou J, Kaldor J, Wodak AD. Four-year follow-up of imprisoned male heroin users and methadone treatment: mortality, re-incarceration and hepatitis C infection. Addiction 2005;100(6):820-828. [DOI: $10.1111 /$ j.1360-0443.2005.01050.x]

Dole 1969 \{published data only\} Dole VP, Robinson MD, Orraca J, Towns E, Searcy P, Caine E. Methadone treatment of randomly selected criminal addicts. New England Journal of Medicine 1969;280: $1372-5$.

Howells 2002 \{published data only\} Howells C, Allen S, Gupta J, Stillwell G, Marsden J, Farrell M. Prison based detoxification for opioid dependence: a randomised double blind controlled trial of lofexidine and methadone.. Drug \& Alcohol Dependence 2002;67(2): $169-76$.
Kinlock 2005 \{published data only\}

Kinlock TW, Battjes RJ, Schwartz RP, MTC Project Team. A novel opioid maintenance program for prisoners: report of post-release outcomes. The American Journal of Drug and Alcohol Abuse 2005; Vol. 31, issue 3:433-54. [: $\mathrm{CN}-00590052$ ]

\section{Kinlock 2007 \{published data only\}}

Gordon MS, Kinlock TW, Schwartz RP, O'Grady KE. A randomized clinical trial of methadone maintenance for prisoners: findings at 6 months post-release. Addiction 2008b;103(8):1333-42.

Kinlock TW, Gordon MS, Schwartz RP, Fitzgerald TT, O'Grady KE. A randomized clinical trial of methadone maintenance for prisoners: results at 12 months post release. Journal of Substance Abuse Treatment 2009;37(3):277-85.

* Kinlock TW, Gordon MS, Schwartz RP, O'Grady K, Fitzgerald TT, Wilson M. A randomized clinical trial of methadone maintenance for prisoners: results at 1-month post-release. Drug and Alcohol Dependence 2007;91(2-3): 220-7.

Kinlock TW, Gordon MS, Schwartz RP, O'Grady KE. A study of methadone maintenance for male prisoners: 3month postrelease outcomes. Criminal Justice Behavior 2008;35(1):34-47.

Wilson ME, Kinlock TW, Gordon MS, O'Grady KE, Schwartz RP. Postprison Release HIV-Risk Behaviors in a Randomized Trial of Methadone Treatment for Prisoners. American Journal on Addictions 2012;21(5):476-87. [DOI: 10.1111/j.1521-0391.2012.00250.x]

Lobmaier 2010 \{published data only\} Lobmaier PP, Kunoe N, Gossop M, Katevoll T, Waal H. Naltrexone implants compared to methadone: outcomes six months after prison release. European Addiction Research 2010;16(3):139-45.

\section{Lobmann 2007 \{published data only\}}

Lobmann R. Diamorphine substitution therapy and criminal activity. Sucht: Zeitschrift fur Wissenschaft und Praxis 2007; Vol. 53, issue 5:288-95. [: CN-00627424]

Magura 2009 \{published data only\} Magura S, Lee JD, Hershberger J, Joseph H, Marsch L, Shropshire C, et al. Buprenorphine and methadone maintenance in jail and post-release: a randomized clinical trial. Drug and Alcohol Dependence 2009; Vol. 99, issue $1-3: 222-30$.

Wright 2011 \{published data only\} Wright N, Sheard L. Comparison of methadone and buprenorphine for opiate detoxification (LEEDS trial): a randomised controlled trial. British Journal of General Practice 2011;61(593):772-80.

References to studies excluded from this review

Pharmacological interventions for drug-using offenders (Review)

Copyright @ 2015 The Cochrane Collaboration. Published by John Wiley \& Sons, Ltd. 
Alemi 2010 \{published and unpublished data\}

Alemi F, Haack M, Nemes S, Harge A, Baghi H. Impact of online counseling on drug use: a pilot study. Quality Management Health Care 2010;19(1):62-9.

Alessi 2011 \{published data only\} Alessi SM, Rash C, Petry NM. Contingency management is efficacious and improves outcomes in cocaine patients with pretreatment marijuana use. Drug and Alcohol Dependence 2011;118(1):62-7.

Andersson 2014 \{published data only\} Andersson C, Vasiljevic Z, Hoglund P, Ojehagen A, Berglund M. Daily automated telephone assessment and intervention improved 1-month outcome in paroled offenders. International Journal Offender Therapy Comparative Criminology 2014; online:1-18. [DOI: 10.1177/0306624X14526800]]

Anglin 1999 \{published data only\}

Anglin MD, Longshore D, Turner S. Treatment alternatives to street crime - An evaluation of five programs. Criminal Justice and Behavior 1999;26(2):168-95.

Awgu 2010 \{published data only\}

Awgu E, Magura S, Rosenblum A. Heroin-dependent inmates' experiences with buprenorphine or methadone maintenance. Journal of Psychoactive Drugs 2010;42(3): $339-46$.

Azbel 2013 \{published data only\}

Azbel L, Wickersham JA, Grishaev Y, Dvoryak S, Altice FL. Burden of infectious diseases, substance use disorders, and mental illness among Ukrainian prisoners transitioning to the community. PLOS ONE 2013;8(3):e59643.

Baldus 2011 \{published data only\}

Baldus C, Miranda A, Weymann N, Reis O, More

K, Thomasius R. "CAN Stop"- implementation and evaluation of a secondary group prevention for adolescent and young adult cannabis users in various contexts- study protocol. BMC Health Services Research 2011;11:80.

Baltieri 2014 \{published data only\}

Baltieri D. A. Order of onset of drug use and criminal activities in a sample of drug-abusing women convicted of violent crimes.. Drug \& Alcohol Review 2014;33(2):202-10.

Barnes 2012 \{published data only\}

Barnes GC, Hyatt JM, Ahlman LC, Kent DTL. The effects of low intensity supervision for lower risk probationers: updated results from a RCT. Journal of Crime and Justice 2012;35(2):200-20.

Berman 2004 \{published data only\}

Berman AH, Lundberg U, Krook AL, Gyllenhammar C. Treating drug using prison inmates with auricular acupuncture: a randomized controlled trial. Journal of Substance Abuse Treatment 2004;26(2):95-102. [0740-5472: (Print)]

Black 2011 \{published data only\}

Black S, Carey E, Webber A, Neish N, Gilbert R.

Determining the efficacy of auricular acupuncture for reducing anxiety in patients withdrawing from psychoactive drugs. Journal of Substance Abuse Treatment 2011;41(3): 279-87.

Brady 2010 \{published data only\}

Brady LLC, Najavits LM, Toussaint D, Bonavota D, Veysey B. Does recent criminal involvement matter? A study of women with co-occurring disorders in a multisite national trial. Mental Health and Substance Use: Dual Diagnosis 2010;3 (3):193-202.

Braithwaite 2005 \{published data only\}

Braithwaite RL, Stephens TT, Treadwell HM, Braithwaite K, Conerly R. Short-term impact of an HIV risk reduction intervention for soon-to-be released inmates in Georgia. Journal of Health Care for the Poor and Underserved 2005;16 (4Suppl B):130-9. [: CN-00532300]

Breckenridge 2000 \{published data only\} Breckenridge JF, Winfree LT, Maupin JR, Clason DL. Drunk drivers, DWI 'drug court' treatment and recidivism: Who fails?. Justice Research and Policy 2000;2:87-105.

Britt 1992 a-d \{published data only\}

* Britt IC, Gottfredson MR, Goldkamp JS. Drug testing and pretrial misconduct: an experiment on the specific deterrent effects of drug monitoring defendants on pretrial release. Journal of Research in Crime and Delinquency 1992; 29(1):62-78.

Brown 2001 \{published data only\} Brown BS, O'Grady KE, Battjes RJ, Farrell EE, Smith NP, Nurco DN. Effectiveness of a stand-alone aftercare program for drug-involved offenders. Journal of Substance Abuse Treatment 2001;21(4):185-92.

Burdon 2013 \{published data only\}

Burdon WM, St De Lore J, Dang J, Warda US, Prendergast ML. Psychosocial Functioning Among Inmates in PrisonBased Drug Treatment: Results from Project BRITE. Journal of Experimental Criminology 2013;9(1):45-64. [DOI: 10.1007/s11292-012-9169-5]

Carr 2008 \{published data only\} Carr CJ, Xu J, Redko C, Lane D, Rapp RC, Goris J, et al. Individual and system influences on waiting time for substance abuse treatment. Journal of Substance Abuse Treatment 2008;34(2):192-201. [: 0740-5472]

Carroll 2006 \{published data only\} Carroll KM, Easton CJ, Nich C, Hunkele KA, Neavins TM, Sinha R, et al. The use of contingency management and motivational/skills-building therapy to treat young adults with marijuana dependence. Journal of Consulting and Clinical Psychology 2006;74(5):955-66. [: 0022-006X]

\section{Carroll 2011 \{published data only\}}

Carroll KM, Kiluk BD, Nich C, Babuscio TA, Brewer JA, Potenza MN, et al. Cognitive function and treatment response in a randomized clinical trial of computer-based training in cognitive-behavioral therapy. Substance Use and Misuse 2011;46(1):23-34.

Carroll 2012 \{published data only\} Carroll KM, Nich C, Lapaglia DM, Peters EN, Easton CJ, Petry NM. Combining cognitive behavioral therapy 
and contingency management to enhance their effects in treating cannabis dependence: less can be more, more or less.. Addiction 2012;107(9):1650-9.

Chandler 2006 \{published data only\}

Chandler DW, Spicer G. Integrated treatment for jail recidivists with co-occurring psychiatric and substance use disorders. Community Mental Health Journal 2006;42(4): 405-25. [0010-3853: (Print)]

Chaple 2014 \{published data only\}

Chaple M, Sacks S, McKendrick K, Marsch LA, Belenko $S$, Leukefeld C, et al. Feasibility of a computerized intervention for offenders with substance use disorders: a research note. Journal of Experimental Criminology 2014;10: $105-27$.

Clair 2013 \{published data only\}

Clair M, Stein LA, Soenksen S, Martin RA, Lebeau R, Golembeske C. Ethnicity as a moderator of motivational interviewing for incarcerated adolescents after release.. Journal of Substance Abuse Treatment 2013;45(4):370-5.

Cogswell 2011 \{published data only\}

Cogswell J, Negley SK. The effect of autonomy- supportive therapeutic recreation programming on integrated motivation for treatment among persons who abuse substances. Therapeutic Recreation Journal 2011;45(1):1st Quarter:47-61.

Cosden 2003 \{published data only\}

* Cosden M, Ellens JK, Schnell JL, Yamini-Diouf Y, Wolfe MM. Evaluation of a mental health treatment court with assertive community treatment. Behavioral Sciences \& the Law 2003;21(4):415-27.

Cosden 2005 \{published data only\}

Cosden M, Ellens J, Schnell J, Yamini-Diouf Y. Efficacy of a mental health treatment court with assertive community treatment. Behavioral Sciences \& the Law 2005;23(2): 199-214. [0735-3936: (Print)]

Coviello 2012 \{published data only\} Coviello DM, Cornish JW, Lynch KG, Boney TY, Clark C, Lee JD, et al. A multisite pilot study of extended release injectable naltrexone treatment for previously opioid dependent parolees and probationers. Substance Abuse 2012;33(1):48-59.

Cox 2013 \{published data only\} Cox BR, Olney JJ, Lowery-Gionta EG, Sprow GM, Rinker JA, Navarro M, et al. Repeated cycles of bingelike ethanol $(\mathrm{EtOH})$-drinking in male $\mathrm{C} 57 \mathrm{BL} / 6 \mathrm{~J}$ mice augments subsequent voluntary $\mathrm{EtOH}$ intake but not other dependence-like phenotypes.. Alcoholism, Clinical and Experimental Research 2013;37(10):1688-95. .

Cropsey 2013 \{published data only\} Cropsey KL, Lane PS, Perkins AC, Clark B, Hardy S, McCullumsmith C, et al. Buprenorphine and Medication management in a community corrections population: A pilot study. Journal of Addict Med 2013;7:210-5.
Cullen 2011 \{published data only\}

Cullen AE, Soria C, Clarke AY, Dean K, Fahy T. Factors

Predicting Dropout from the Reasoning and Rehabilitation Program with Mentally Disordered Offenders.. Criminal Justice and Behavior 2011;38(3):217-30. [DOI: 10.1177/ 0093854810393659]

Cusack 2010 \{published data only\}

Cusack KJ, Morrissey JP, Cuddeback GS, Prins A, Williams DM. Criminal justice involvement, behavioral health service use, and costs of forensic assertive community treatment: a randomized trial. Community Mental Health Journal 2010; 46(4):356-63.

D'Amico 2013 \{published data only\} D'Amico EJ, Hunter SB, Miles JN, Ewing BA, Osilla KC. A randomized controlled trial of a group motivational interviewing intervention for adolescents with a first time alcohol or drug offense.. Journal of Substance Abuse Treatment 2013;45(5):400-8.

Dakof 2010 \{published data only\} Dakof GA, Cohen JB, Henderson CE, Duarte E, Boustani M, Blackburn A, et al. A randomized pilot study of the Engaging Moms Program for family drug court. Journal of Substance Abuse Treatment 2010;38(3):263-74.

Dana 2013 \{published data only\}

Dana D, Zary N, Peyman A, Behrooz A. Risk prison and hepatitis $B$ virus infection among inmates with history of drug injection in Isfahan, Iran.. Scientific World Journal 2013;735761:1-4.

DeFulio 2013 \{published data only\}

DeFulio A, Stitzer M, Roll J, Petry N, Nuzzo P, Schwartz RP, et al. Criminal justice referral and incentives in outpatient substance abuse treatment.. Journal of Substance Abuse Treatment 2013;45(1):70-5. [DOI: http://dx.doi.org/ $10.1016 /$ j.jsat.2012.12.012]

Dembo 2000 \{published data only\}

Dembo R, Ramirez GG, Rollie M, Schmeidler J, Livingston $S$, Hartsfield A. Youth recidivism twelve months after a family empowerment intervention: final report. Journal of Offender Rehabilitation 2000;31(3/4):29-65.

Deschenes 1994 \{published data only\} * Deschenes EP, Greenwood PW. Maricopa-County Drug Court - an innovative program for 1st-time drug offenders on probation. Justice System Journal 1994;17(1):99-115.

Diamond 2006 \{published data only\} Diamond G, Panichelli-Mindel SM, Shrea D, Dennis M, Tims F, Ungemack J. Psychiatric syndromes in adolescents with marijuana abuse and dependency in outpatient treatment. Journal of Child \& Adolescent Substance Abuse 2006; Vol. 15, issue 4:37-54.

Di Nitto 2002 \{published data only\} Di Nitto DM, Webb DK, Rubin A. The effectiveness of an integrated treatment approach for clients with dual diagnoses. Research on Social Work Practice 2002;12(5): 621-41. 
Dugan 1998 \{published data only\}

Dugan JR, Everett RS. An experimental test of chemical dependency therapy for jail inmates. International Journal of Offender Therapy \& Comparative Criminology 1998;42(4): $360-8$.

Evans 2012 \{published data only\}

Evans E, Jaffe A, Urada D, Anglin MD. Differential outcomes of court-supervised substance abuse treatment among California parolees and probationers.. International Journal of Offender Therapy and Comparative Criminology 2012;56(4):539-56.

Forsberg 2011 \{published data only\} Forsberg LG, Ernst D, Sundqvist K, Farbring CA. Motivational Interviewing delivered by existing prison staff: a randomized controlled study of effectiveness on substance use after release. Substance Use and Misuse 2011;46(12): 1477-85.

Freudenberg 2010 \{published data only\} Freudenberg N, Ramaswamy M, Daniels J, Crum M, Ompad DC, Vlahov D. Reducing drug use, human immunodeficiency virus risk, and recidivism among young men leaving jail: evaluation of the REAL MEN re-entry program. Journal of Adolescent Health 2010;47(5):448-55.

Friedman 2012 \{published data only\} Friedman SR, West BS, Pouget ER, Hall HI, Cantrell J, Tempalski B, et al. Metropolitan Social Environments and Pre-HAART/HAART Era Changes in Mortality Rates (per 10,000 Adult Residents) among Injection Drug Users Living with AIDS.. PLoS ONE 2013;8(2):12. [DOI: e5720110.1371/journal.pone.0057201]

Frost 2013 \{published data only\}

Frost M, Iacobacci B. Utilization of buprenorphine assisted opioid dependence treatment in a county drug court program.. Journal of Addiction Medicine 2013;7(4):E10.

Gagnon 2010 \{published data only\}

Gagnon H, Godin G, Alary M, Bruneau J, Otis J. A randomized trial to evaluate the efficacy of a computertailored intervention to promote safer injection practices among drug users. AIDS \& Behavior 2010;14(3):538-48.

Gil 2004 \{published data only\}

Gil AG, Wagner EF, Tubman JG. Culturally sensitive substance abuse intervention for Hispanic and African American adolescents: empirical examples from the Alcohol Treatment Targeting Adolescents in Need (ATTAIN) Project. Addiction 2004;99(Suppl 2):140-50. [: 0965-2140]

Gordon 2012 \{published data only\} Gordon M, Kinlock TW, Couvillion KA, Schwartz RP, O'Grady K. A Randomized Clinical Trial of Methadone Maintenance for Prisoners: Prediction of Treatment Entry and Completion in Prison. Journal of Offender Rehabilitation 2012;51(4):222-38.

Gordon 2013 \{published data only\} Gordon MS, Kinlock TW, Couvillion KA, Wilson ME, Schwartz RP, O'Grady KE. Gender Differences
Among Prisoners With Pre-Incarceration Heroin Dependence Participating in a Randomized Clinical Trial of Buprenorphine Treatment. Journal of Offender Rehabilitation 2013;52(5):376-91.

Gottfredson 2002 \{published data only\}

* Gottfredson DC, Exum ML. The Baltimore City drug treatment court: one-year results from a randomized study. Journal of Research in Crime and Delinquency 2002;39(3): $337-56$.

Grohman 2002 \{published data only\} Grohman K, Fals-Stewart W, Bates ME. Cognitive rehabilitation for neuropsychologically impaired substanceabusing patients: posttreatment outcomes [web page]. http: //addictionandfamily.org [2004, 29 Oct] 2002.

Grommon 2013a \{published data only\} Grommon E, Cox SM, Davidson WS, Bynum TS. Alternative models of instant drug testing: Evidence from an experimental trial. Journal of Experimental Criminology 2013;9(2):145-68. [DOI: http://dx.doi.org/10.1007/ s11292-012-9168-6]

Grommon 2013b \{published data only\} Grommon E, Davidson WS, Bynum TS. A randomized trial of a multimodal community-based prisoner reentry program emphasizing substance abuse treatment. Journal of Offender Rehabilitation 2013;52(4):287-309. [DOI: http:// dx.doi.org/10.1080/10509674.2013.782775]

Guydish 2011 \{published data only\} Guydish J, Chan M, Bostrom A, Jessup M, Davis T, Marsh C. A randomized trial of probation case management for drug-involved women offenders. Crime and Delinquency 2011;57(2):167-98.

Guydish 2014 \{published data only\} Guydish J, Campbell BK, Manuel JK, Delucchi KL, Le T, Peavy KM, et al. Does treatment fidelity predict client outcomes in 12-Step Facilitation for stimulant abuse?. Drug \& Alcohol Dependence 2014;134:330-36.

Haapanen 2002 \{published data only\}

* Haapanen R, Britton L. Drug testing for youthful offenders on parole: an experimental evaluation. Criminology and Public Policy 2002;1(2):217-44.

Haasen 2010 \{published data only\}

Haasen C, Verthein U, Eiroa-Orosa FJ, Schäfer I, Reimer J. Is heroin-assisted treatment effective for patients with no previous maintenance treatment? Results from a German randomised controlled trial. European Addiction Research 2010;16(3):124-30.

Hanlon 1999 \{published data only\}

* Hanlon TE, Bateman RW, O'Grady KE. The relative effects of three approaches to the parole supervision of narcotic addicts and cocaine abusers. Prison Journal 1999; 79(2):163-81.

Harada 2012 \{published data only\}

Harada T. The randomized controlled trial of the prison-based Japanese Matrix Program (J-MAT) for 
methamphetamine abusers. Japanese Journal of Alcohol Studies and Drug Dependence 2012;47(6):298-307.

Harrell 2001 \{published data only\}

Harrell A, Roman J. Reducing drug use and crime among offenders: the impact of graduated sanctions. Journal of Drug Issues 2001;31(1):207-32.

Henderson 2010 \{published data only\} Henderson CE, Dakof GA, Greenbaum PE, Liddle HA. Effectiveness of multidimensional family therapy with higher severity substance-abusing adolescents: report from two randomized controlled trials. Journal of Consulting in Clinical Psychology 2010;78(6):885-97.

Henggeler 1991 \{published data only\} Henggeler SW, Borduin CM, Melton GB, Mann BJ. Effects of multisystemic therapy on drug use and abuse in serious juvenile offenders: a progress report from two outcome studies. Family Dynamics of Addiction Quarterly 1991;1(3): 40-51.

Henggeler 1999 \{published data only\}

* Henggeler SW, Pickrel SG, Brondino MJ. Multisystemic treatment of substance-abusing and dependent delinquents: outcomes, treatment fidelity, and transportability. Mental Health Services Research 1999;1(3):171-84.

Henggeler 2002 \{published data only\} Henggeler SW, Clingempeel WG, Brondino MJ, Pickrel SG. Four-year follow-up of multisystemic therapy with substance-abusing and substance-dependent juvenile offenders. Journal of the American Academy of Child \& Adolescent Psychiatry 41;7:868-74.

Henggeler 2006 \{published data only\} Henggeler SW, Halliday-Boykins CA, Cunningham PB, Randall J, Shapiro SB, Chapman JE. Juvenile drug court: enhancing outcomes by integrating evidence-based treatments. Journal of Consulting in Clinical Psychology 2006;74(1):42-54. [0022-006X: (Print)]

Henggeler 2012 \{published data only\}

Henggeler SW, McCart MR, Cunningham PB, Chapman JE. Enhancing the effectiveness of juvenile drug courts by integrating evidence-based practices. Journal of Consulting \& Clinical Psychology 2012;80(2):264-75. [DOI: 10.1037/ a0027147]

Hser 2011 \{published data only\} Hser Y-I, Li J, Jiang H, Zhang R, Du J, Zhang C, et al. Effects of a randomized contingency management intervention on opiate abstinence and retention in methadone maintenance treatment in China. Addiction 2011;106(10):1801-9.

Hser 2013 \{published data only\}

Hser Y-I, Fu L, Wu F, Du J, Zhao M. Pilot trial of a recovery management intervention for heroin addicts released from compulsory rehabilitation in China. Journal of Substance Abuse Treatment 2013;44(1):78-83. [DOI: http://dx.doi.org/10.1016/j.jsat.2012.03.009]

Inciardi 2004 \{published data only\} Inciardi JA, Martin SS, Butzin CA. Five-year outcomes of therapeutic community treatment of drug-involved offenders after release from prison. Crime \& Delinquency 2004;50(1):88-107. [: 0011-1287]

Jain 2011 \{published data only\}

Jain K, Jain R, Dhawan A. A double-blind, double-

dummy, randomized controlled study of memantine versus buprenorphine in naloxone-precipitated acute withdrawal in heroin addicts. J Opioid Manag 2011;7(1):11-20.

Johnson 2011 \{published data only\} Johnson JE, Friedmann PD, Green TC, Harrington M, Taxman FS. Gender and treatment response in substance use treatment-mandated parolees. Journal of Substance Abuse Treatment 2011;40(3):313-21.

Johnson 2012 \{published data only\}

Johnson JE, Zlotnick C. Pilot study of treatment for major depression among women prisoners with substance use disorder. Journal of Psychiatric Research 2012;46(9): 1174-83.

Jones, 2011 \{published data only\} Jones RK. Evaluation of the DUI court program in Maricopa County, Arizona.. Washington, DC: U.S. Department of Transportation. 2011; Vol. Report.

Jones 2013 \{published data only\}

Jones CG. Early-phase outcomes from a randomized trial of intensive judicial supervision in an Australian Drug Court. Criminal Justice and Behavior 2013;40(4):453-68. [DOI: http://dx.doi.org/10.1177/0093854812449215]

Katz 2007 \{published data only\}

Katz EC, Brown BS, Schwartz RP, King SD, Weintraub E, Barksdale W. Impact of role induction on long-term drug treatment outcomes. Journal of Addictive Diseases 2007;26 (2):81-90. [: CN-00590052]

Kelly 2013 \{published data only\}

Kelly SM, O'Grady KE, Jaffe JH, Gandhi D, Schwartz RP. Improvements in outcomes in methadone patients on probation/parole regardless of counseling early in treatment. Journal of Addiction Medicine 2013;7(2):133-8. [DOI: http://dx.doi.org/10.1097/ADM.0b013e318284a0c1]

Kidorf 2013 \{published data only\} Kidorf M, Brooner RK, Gandotra N, Antoine D, King VL, Peirce J, et al. Reinforcing integrated psychiatric service attendance in an opioid-agonist program: a randomized and controlled trial. Drug and Alcohol Dependence 2013; 133(1):30-6.

King 2014 \{published data only\}

King VL, Brooner RK, Peirce JM, Kolodner K, Kidorf MS. A randomized trial of Web-based videoconferencing for substance abuse counseling.. Journal of Substance Abuse Treatment 2014;466(1):36-42.

Kinlock 2008 \{published data only\} Kinlock TW, Gordon MS, Schwartz RP, O'Grady KE. A study of methadone maintenance for male prisoners: 3month postrelease outcomes. Criminal Justice and Behavior 2008; Vol. 35, issue 1:34-47. [0093-8548: (Print)]

Kinlock 2009a \{published data only\}

Kinlock T, Gordon M, Schwartz R. Buprenorphine for prisoners: preliminary findings at one-month post release. 
Conference Papers -- American Society of Criminology. 2009:1.

\section{Kinlock 2009b \{published data only\}}

Kinlock TW, Gordon MS, Schwartz RP, Fitzgerald TT, O'Grady KE. A randomized clinical trial of methadone maintenance for prisoners: Results at 12 months postrelease. Journal of Substance Abuse Treatment 2009; Vol. 37, issue 3:277-85. [: 0740-5472]

Kok 2013 \{published data only\}

Kok T, de Haan HA, van der Meer M, Najavits LM, DeJong CAJ. Efficacy of "seeking safety" in a Dutch population of traumatized substance-use disorder outpatients: study protocol of a randomized controlled trial. $B M C$ Psychiatry 2013;13(8):162-70. [DOI: 16210.1186/ 1471-244x-13-162]

Law 2012 \{published data only\} Law FM, Guo GJ. Hope and recovery from substance abuse for female drug offenders in Taiwan. International journal of offender therapy and comparative criminology 2012;56(8): 1258-82.

Lee 2012 \{published data only\}

Lee JD, Grossman E, Truncali A, Rotrosen J, Rosenblum A, Magura S, et al. Buprenorphine-naloxone maintenance following release from jail. Subst Abus 2012;33(1):40-7. [DOI: 10.1080/08897077.2011.620475]

Liddle 2011 \{published data only\}

Liddle HA, Dakof GA, Henderson C, Rowe C. Implementation outcomes of multidimensional family therapy-detention to community: a reintegration program for drug-using juvenile detainees. International Journal of Offender Therapy and Comparative Criminology 2011;55(4): 587-604.

Ling 2013 \{published data only\} Ling Murtaugh K, Krishnamurti T, Davis AL, Reback CJ, Shoptaw S. Spend today, clean tomorrow: predicting methamphetamine abstinence in a randomized controlled trial. Health Psychology 2013;32(9):958-66.

Lobmann 2009 \{published data only\}

Lobmann R, Verthein U. Explaining the effectiveness of heroin-assisted treatment on crime reductions. Law and Human Behavior 2009;33(1):83-95. [DOI: 10.1007/ s10979-008-9138-8]

MacDonald 2007 \{published data only\} MacDonald JM, Morral AR, Raymond B, Eibner C. The efficacy of the Rio Hondo DUI court: A 2-year field experiment. Evaluation Review 2007;31(4):4-23.

Marlowe 2003 \{published data only\}

Marlowe DB, Festinger DS, Lee PA, Schepise MM, Hazzard JER, Merrill JC, et al. Are judicial status hearings a key component of drug court? During treatment data from a randomized trial. Criminal Justice and Behavior 2008;30(2): $141-62$.

Marlowe 2005 \{published data only\}

Marlowe DB, Festinger DS, Dugosh KL, Lee PA. Are judicial status hearings a "key component" of drug court?
Six and twelve month outcomes. Drug and Alcohol

Dependence 2005;79(2):145-55.

Marlowe 2007 \{published data only\}

Marlowe DB, Festinger DS, Dugosh KL, Lee PA, Benasutti KM. Adapting judicial supervision to the risk level of drug offenders: discharge and 6-month outcomes from a prospective matching study. Drug and Alcohol Dependence 2007;88(Suppl 2):S4-S13.

Marlowe 2008 \{published data only\}

Marlowe DB, Festinger DS, Dugosh KL, Arabia PL, Kirby KC. An effectiveness trial of contingency management in a felony preadjudication drug court. Journal of Applied Behavior Analysis 2008;41(4):565-77. [0021-8855: (Print)]

Marsch 2014 \{published data only\} Marsch LA, Guarino H, Acosta M, Aponte-Melendez Y, Cleland C, Grabinski M, et al. Web-based behavioral treatment for substance use disorders as a partial replacement of standard methadone maintenance treatment. Journal of Substance Abuse Treatment 2014;46(1):43-51.

Martin 1993 \{published data only\}

* Martin SS, Scarpitti SR. An intensive case management approach for paroled IV drug users. Journal of Drug Issues 1993;23(1):43-59.

Mbilinyi 2011 \{published data only\} Mbilinyi LF, Neighbors C, Walker DD, Roffman RA, Zegree J, Edleson J, et al. A telephone intervention for substance-using adult male perpetrators of intimate partner violence. Research on Social Work Practice 2011;21(1): 43-56.

McKendrick 2007 \{published data only\} McKendrick K, Sullivan C, Banks S, Sacks S. Modified therapeutic community treatment for offenders with MICA disorders: antisocial personality disorder and treatment outcomes. Journal of Offender Rehabilitation 2006; Vol. 44, issue 2-3:133-59. [: 1050-9674]

McKenzie 2012 \{published data only\}

McKenzie M, Zaller N, Dickman SL, Green TC, Parihk A, Friedmann PD, et al. A randomized trial of methadone initiation prior to release from incarceration. Substance Abuse 2012;33(1):19-29. [DOI: 10.1080/ 08897077.2011.609446]

Messina 2000 \{published data only\} Messina N, Wish E, Nemes S. Predictors of treatment outcomes in men and women admitted to a therapeutic community. American Journal of Drug \& Alcohol Abuse 2000;26(2):207-27.

Messina 2010 \{published data only\}

Messina N, Grella CE, Cartier J, Torres S. A randomized experimental study of gender-responsive substance abuse treatment for women in prison.. Journal of Substance Abuse Treatment 2010;38(2):97-107.

Milloy 2011 \{published data only\} Milloy MJS, Kerr T, Zhang R, Tyndall M, Montaner J. Randomised Trial of the Effectiveness of Naloxone. London: Department of Health, 2011. 
Needels 2005 \{published data only\}

Needels K, James-Burdumy S, Burghardt J. Community case management for former jail inmates: its impacts on rearrest, drug use, and HIV risk. Journal of Urban Health 2005;82(3):420-33. [1099-3460: (Print)]

Nemes 1998 \{published data only\}

Nemes S, Wish E, Messina N. The District of Columbia Treatment Initiative (DCI) final report. College Park, MD: University of Maryland, National Evaluation Data and Technical Assistance Center (NEDTAC), 1998.

Nemes 1999 \{published data only\}

Nemes S, Wish ED, Messina N. Comparing the impact of standard and abbreviated treatment in a therapeutic community: findings from the District of Columbia treatment initiative experiment. Journal of Substance Abuse Treatment 1999;17(4):339-47.

Nielsen 1996 \{published data only\}

Farrell A. Women, crime and drugs: testing the effect of therapeutic communities. Women and Criminal Justice 2000;11(1):21-48.

* Nielsen AL, Scarpitti FR, Inciardi JA. Integrating the therapeutic community and work release for drug-involved offenders: the CREST program. Journal of Substance Abuse Treatment 1996;13(4):349-58.

Nosyk 2010 \{published data only\}

Nosyk B, Geller J, Guh DP, Oviedo-Joekes E, Brissette $S$, Marsh DC, et al. The effect of motivational status on treatment outcome in the North American Opiate Medication Initiative (NAOMI) study. Drug and Alcohol Dependence 2010;111(1-2):161-5.

Petersilia 1992 \{published data only\}

* Petersilia J, Turner S, Deschenes EP. Intensive supervision programs for drug offenders. In: Byrne JM, Lurigio AJ editor(s). Smart Sentencing: The Emergence of Intermediate Sanctions. Thousand Oaks, CA: Sage Publications Inc, 1992:18-37.

Petry 2005 \{published data only\}

Petry NM, Peirce JM, Stitzer ML, Blaine J, Roll JM, Cohen A, et al. Effect of prize-based incentives on outcomes in stimulant abusers in outpatient psychosocial treatment programs: a national drug abuse treatment clinical trials network study. Archives of General Psychiatry 2005;62(10): 1148-56. [DOI: 10.1001/archpsyc.62.10.1148]

Petry 2011 \{published data only\} Petry NM, Ford J D, Barry D. Contingency management is especially efficacious in engendering long durations of abstinence in patients with sexual abuse histories. Psychology of Addictive Behaviors 2011;25(2):293-300.

Polsky 2010 \{published data only\} Polsky D, Glick HA, Yang J, Subramaniam GA, Poole SA, Woody GE. Cost-effectiveness of extended buprenorphinenaloxone treatment for opioid-dependent youth: data from a randomized trial. Addiction 2010;105(9):1616-24.
Prendergast 2003 \{published data only\}

Prendergast ML, Hall EA, Wexler HK. Multiple measures of outcome in assessing a prison-based drug treatment program. Journal of Offender Rehabilitation 2003;37:65-94.

Prendergast 2008 \{published data only\} Prendergast ML, Hall EA, Roll J, Warda U. Use of vouchers to reinforce abstinence and positive behaviors among clients in a drug court treatment program. Journal of Substance Abuse Treatment 2008;35(2):125-36. [1873-6483: (Electronic)]

Prendergast 2009 \{published data only\} Prendergast M, Greenwell L, Cartier J, Sacks J, Frisman $\mathrm{L}$, Rodis E, et al. Adherence to scheduled sessions in a randomized field trial of case management: the Criminal Justice-Drug Abuse Treatment Studies Transitional Case Management Study. Journal of Experimental Criminology 2009;5(3):273-97.

Prendergast 2011 \{published data only\} Prendergast M, Frisman L, Sacks JY, Staton-Tindall M, Greenwell L, Lin HJ, et al. A multi-site, randomized study of strengths-based case management with substance-abusing parolees. Journal of Experimental Criminology 2011;7(3): 225-53.

Proctor 2012 \{published data only\} Proctor SL, Hoffmann NG, Allison S. The effectiveness of interactive journaling in reducing recidivism among substance-dependent jail inmates. International Journal of Offender Therapy and Comparative Criminology 2012;56(2): 317-32.

Reimer 2011 \{published data only\}

Reimer J, Verthein U, Karow A, Schäfer I, Naber D, Haasen C. Physical and mental health in severe opioid-dependent patients within a randomized controlled maintenance treatment trial. Addiction 2011;106(9):1647-55.

Robertson 2006 \{published data only\} Robertson JR, Raab GM, Bruce M, McKenzie JS, Storkey HR, Salter A. Addressing the efficacy of dihydrocodeine versus methadone as an alternative maintenance treatment for opiate dependence: a randomized controlled trial. Addiction 2006;101(12):1752-9. [: CN-00577209]

Rosengard 2008 \{published data only\} Rosengard C, Stein LAR, Barnett NP, Monti PM, Golembeske C, Lebeau-Craven R, et al. Randomized clinical trial of motivational enhancement of substance use treatment among incarcerated adolescents. Journal of HIVI AIDS Prevention in Children and Youth 2008;8(2):45-64.

Rossman 1999 \{published data only\}

Rossman S, Sridharan S, Gouvis C, Buck J, Morley E. Impact of the Opportunity to Succeed (OPTS) Aftercare Program for Substance-Abusing Felons: comprehensive Final Report. Washington DC: Urban Institute, 1999.

Rounsaville 2001 \{published data only\} Rounsaville BJ, Carroll KM, Onken LS. A Stage Model of Behavioral Therapies research: Getting started and moving on from stage I. Clinical Psychology-Science and Practice 2001;8(2):133-42. [DOI: 10.1093/clipsy/8.2.133] 
Rowan-Szal 2005 \{published data only\}

Rowan-Szal GA, Bartholomew NG, Chatham LR, Simpson DD. A combined cognitive and behavioral intervention for cocaine-using methadone clients. Journal of Psychoactive Drugs 2005;37(1):75-84.

Rowan-Szal 2009 \{published data only\}

Rowan-Szal GA, Joe GW, Simpson D, Greener JM, Vance J. During-treatment outcomes among female methamphetamine-using offenders in prison-based treatments. Journal of Offender Rehabilitation 2009;48(5): $388-401$.

Rowe 2007 \{published data only\}

Rowe M, Bellamy C, Baranoski M, Wieland M, Connell $\mathrm{MJO}$, Benedict $\mathrm{P}$, et al. A peer-support, group intervention to reduce substance use and criminality among persons with severe mental illness. Psychiatric Services 2007;58(7): 955-61. [: 1075-2730]

Sacks 2004 \{published data only\}

Sacks S, Sacks JY, McKendrick K, Banks S, Stommel J. Modified TC for MICA inmates in correctional settings: crime outcomes. Behavioural Sciences and the Law 2004;22 (4):477-501.

Sacks 2008 \{published data only\}

Sacks JY, Sacks S, McKendrick K, Banks S, Schoeneberger M, Hamilton Z, et al. Prison therapeutic community treatment for female offenders: profiles and preliminary findings for mental health and other variables (crime, substance use and HIV risk). Journal of Offender Rehabilitation 2008;46(3-4):233-61. [: 1050-9674]

Sacks 2011 \{published data only\}

Sacks S, Chaple M, Sacks JY, McKendrick K, Cleland CM. Randomized trial of a reentry modified therapeutic community for offenders with co-occurring disorders: crime outcomes. Journal of Substance Abuse Treatment 2012;42(3): 247-59.

Sanchez-Hervas 2010 \{published data only\}

Sanchez-Hervas E, Secades-Villa R, Romaguera FZ, Fernandez GG, Gomez FJS, Garcia-Rodriguez O. Behavioral therapy for cocaine addicts: outcomes of a follow-up six month study. Revista Mexicana De Psicologia 2010;27(2):159-67.

Schaeffer 2014 \{published data only\}

Schaeffer CM, Henggeler SW, Ford JD, Mann M, Chang R, Chapman JE. RCT of a promising vocational/employment program for high-risk juvenile offenders. Journal of Substance Abuse Treatment 2014;46(2):134-43. [DOI: http: //dx.doi.org/10.1016/j.jsat.2013.06.012]

Schmiege 2009 \{published data only\}

Schmiege SJ, Broaddus MR, Levin M, Bryan AD. Randomized Trial of Group Interventions to Reduce HIV/ STD Risk and Change Theoretical Mediators Among Detained Adolescents. Journal of Consulting and Clinical Psychology 2009;77(1):38-50. [DOI: 10.1037/A0014513]

Schwartz 2006 \{published data only\} Schwartz RP, Highfield DA, Jaffe JH, Brady JV, Butler CB, Rouse $\mathrm{CO}$, et al. A randomized controlled trial of interim methadone maintenance. Archives of General Psychiatry

2006;63(1):102-9.

Shanahan 2004 \{published data only\}

Shanahan M, Lancsar E, Haas M, Lind B, Weatherburn D, Chen S. Cost-effectiveness analysis of the New South Wales adult drug court program. Evaluation Review 2004;28(1): 3-27.

Sheard 2009 \{published data only\}

Sheard L, Wright NM, El-Sayeh CE, Adams C, Li $\mathrm{R}$, Tompkins CN. The Leeds evaluation of efficacy of detoxification study (LEEDS) prisons project: a randomised controlled trial comparing dihydrocodeine and buprenorphine for opiate detoxification. Substance Abuse Treatment Prevention and Policy 2009;4:1.

Siegal 1999 \{published data only\} Siegal HA, Jichuan W, Carlson RG, Falck RS, Rahman AM, Fine RL. Ohio's prison-based therapeutic community treatment programs for substance abusers: preliminary analysis of re-arrest data. Journal of Offender Rehabilitation 1999;28(3/4):33-48.

Sinha 2003 \{published data only\}

Sinha R, Easton C, Renee-Aubin L, Carroll KM. Engaging young probation-referred marijuana-abusing individuals in treatment: a pilot trial. American Journal on Addictions 2003;12(4):314-23.

Smith 2010 \{published data only\}

Smith DK, Chamberlain P, Eddy JM. Preliminary support for multidimensional treatment foster care in reducing substance use in delinquent boys. Journal of Child \& Adolescent Substance Abuse 2010;19:343-58.

Solomon 1995 \{published data only\}

Solomon P, Draine J. One-Year Outcomes of a Randomized Trial of Case-Management with Seriously Mentally-Ill Clients Leaving Jail.. Evaluation Review 1995;19(3): 256-73. [DOI: 10.1177/0193841x9501900302]

Specka 2013 \{published data only\}

Specka M, Boning A, Kluwig J, Schifano F, Banger M, Lange W, et al. Can reinforcement-based interventions to reduce drug use successfully be adapted to routine opioid maintenance treatment?. Annali dell Istituto Superiore di Sanita 2013;49(4):358-64.

Stanger 2009 \{published data only\}

Stanger C, Budney AJ, Kamon JL, Thostensen J. A randomized trial of contingency management for adolescent marijuana abuse and dependence. Drug and Alcohol Dependence 2009;105(3):240-7. [: 0376-8716]

Staton-Tindall 2009 \{published data only\} Staton-Tindall M, McNees E, Leukefeld CG, Walker R, Thompson L, Pangburn K, et al. Systematic outcomes research for corrections-based treatment: implications from the criminal justice Kentucky treatment outcome study. Journal of Offender Rehabilitation 2009;48(8):710-24.

Stein 2006 \{published data only\}

Stein LA, Monti PM, Colby SM, Barnett NP, Golembeske C, Lebeau-Craven R, et al. Enhancing Substance Abuse 
Treatment Engagement in Incarcerated Adolescents. Psychol Serv 2006;3(1):25-34.

Stein 2010 \{published data only\}

Stein MD, Herman DS, Kettavong M, Cioe PA, Friedmann PD, Tellioglu T, et al. Antidepressant treatment does not improve buprenorphine retention among opioid-dependent persons. Journal of Substance Abuse Treatment 2010;39(2): 157-66.

Stein 2011 \{published data only\}

Stein LA, Clair M, Lebeau R, Colby SM, Barnett NP, Golembeske CM, et al. Motivational interviewing to reduce substance-related consequences: effects for incarcerated adolescents with depressed mood. Drug and Alcohol Dependence 2011;118(2-3):475-8.

Stevens 1998 \{published data only\}

Stevens SJ, Patton T. Residential treatment for drug addicted women and their children: Effective treatment strategies. Drugs \& Society 1998;13(1-2):235-49.

Svikis 2011 \{published data only\}

Svikis DS, Keyser-Marcus L, Stitzer M, Rieckmann T, Safford L, Loeb P, et al. Randomized multi-site trial of the Job Seekers' Workshop in patients with substance use disorders. Drug and Alcohol Dependence 2012;1 (1,20):1-3.

Taxman 2006 \{published data only\}

Taxman FS, Meridith T. Risk, need, and responsivity (RNR): it all depends. Crime \& Delinquency 2006;52(1): 28-51. [0095-2990: (Print)]

Vagenas 2014 \{published data only\}

Vagenas P, Di Paola A, Herme M, Lincoln T, Skiest DJ, Altice FL, et al. An evaluation of hepatic enzyme elevations among HIV-infected released prisoners enrolled in two randomized placebo-controlled trials of extended release naltrexone. Journal of Substance Abuse Treatment 2014;47 (1):35-40.

Vanderberg 2002 \{published data only\} Vanderberg SA. Motivational interviewing as a precursor to a substance abuse program for offenders. Doctoral thesis, Department of Psychology, Carlton University, Ottawa, Ontario 2002.

Villagrá Lanza 2013 \{published data only\} Villagrá Lanza P, González Menéndez A. Acceptance and Commitment Therapy for drug abuse in incarcerated women. Psicothema 2013;25(3):307-12.

Walters 2014 \{published data only\}

Walters ST, Ondersma SJ, Ingersoll KS, Rodriguez M, Lerch J, Rossheim ME, et al. MAPIT: development of a web-based intervention targeting substance abuse treatment in the criminal justice system. Journal of Substance Abuse Treatment 2014;46(1):60-5.

Wang 2010 \{published data only\}

Wang EA, Moore BA, Sullivan LE, Fiellin DA. Effect of incarceration history on outcomes of primary care officebased buprenorphine/naloxone. Journal of General Internal Medicine 2010;25(7):670-4.
Webster 2014 \{published data only\}

Webster JM, Staton-Tindall M, Dickson MF, Wilson JF, Leukefeld CG. Twelve-month employment intervention outcomes for drug-involved offenders.. American Journal of Drug and Alcohol Abuse 2014;40(3):200-5. [DOI: 10.3109/00952990.2013.858722]

White 2006 \{published data only\} White MD, Goldkamp JS, Robinson JB. Acupuncture in drug treatment: exploring its role and impact on participant behavior in the drug court setting. Journal of Experimental Criminology 2006;2(1):45-65. [: 1573-3750]

Williams 2011 \{published data only\} Williams K, Martin M, Martin D. Examining a drug court treatment program in New Jersey: a perspective from the field. Alcoholism Treatment Quarterly 2011;29(1):85-90.

Winstanley 2011 \{published data only\} Winstanley EL, Bigelow GE, Silverman K, Johnson RE, Strain EC. A randomized controlled trial of fluoxetine in the treatment of cocaine dependence among methadonemaintained patients. Journal of Substance Abuse Treatment 2011;40(3):255-64.

Witkiewitz 2010 \{published data only\}

Witkiewitz K, Bowen S. Depression, craving, and substance use following a randomized trial of mindfulness-based relapse prevention. Journal of Consulting in Clinical Psychology 2010;78(3):362-74.

Wolff 2012 \{published data only\} Wolff N, Frueh BC, Shi J, Schumann BE. Effectiveness of cognitive-behavioral trauma treatment for incarcerated women with mental illnesses and substance abuse disorders. Journal of Anxiety Disorders 2012;26(7):703-10. [DOI: 10.1016/j.janxdis.2012.06.001]

Zlotnick 2009 \{published data only\} Zlotnick C, Johnson J, Najavits LM. Randomized controlled pilot study of cognitive-behavioral therapy in a sample of incarcerated women with substance use disorder and PTSD. Behavior Therapy 2009;40(4):325-36. [: 0005-7894]

\section{References to ongoing studies}

\section{Springer 2015 \{unpublished data only\}} Springer SA. Naltrexone for opioid dependent released HIV+ Criminal Justice Populations.. (ongoing-2015) to be confirmed.

\section{Additional references}

\section{Amato 2005}

Amato L, Davoli M, Perucci CA, Ferri M, Faggiano F, Mattick RP. An overview of systematic reviews of effectiveness of opiate maintenance therapies: available evidence to information clinical practice and research. Journal of Substance Abuse Treatment 2005;28:321-9.

Amato 2013

Amato L, Davoli M, Minozzi S, Ferroni E, Ali R, Ferri M. Methadone at tapered doses for the management of opioid 
withdrawal. Cochrane Database of Systematic Reviews 2013, Issue 2. [DOI: 10.1002/14651858.CD003409.pub3]

\section{Binswanger 2007}

Binswanger IA, Stern MF, Deyo RA, Heagerty PJ, Cheadle

A, Elmore JG, et al. Release from prison- a high risk of death for former inmates. New England Journal of Medicine 2007;356:157-65.

Bird 2003

Bird SM, Hutchinson SJ. Male drugs related deaths in the fortnight after release from prison: Scotland 1996-99. Addiction 2003;98:185-90.

Brooke 1996

Brooke D, Taylor C, Gunn J, Maden A. Point prevalence of mental disorder in unconvicted male prisoners in England and Wales. British Medical Journal 1996;313:1524-7.

\section{Catania 2003}

Catania H. Prison health needed in prisons. Harm reduction news: Newsletter of the International Harm Reduction Development Program of the Open Society Institute. Open Society Institute 2003; Vol. 4, issue 11:13.

Chanhatasilpa 2000

Chanhatasilpa C, Mackenzie DL, Hickman LJ. The effectiveness of community-based programs for chemically dependent offenders: a review and assessment of the research. Journal of Substance Abuse Treatment 2000;19: 383-93.

\section{Drummond 1997}

Drummond M, O'Brien B, Stoddart G, Torrance G. Methods for the Economic Evaluation of Health Care Programmes. 2nd Edition. Oxford, UK: Oxford University Press, 1997.

\section{Egg 2000}

Egg R, Pearson FS, Cleland CM, Lipton DS. Evaluations of correctional treatment programs in Germany: a review and meta-analysis. Substance Use and Misuse 2000;35(12-14): 1967-2009.

\section{Faggiano 2003}

Faggiano F, Vigna-Taglianti F, Versino E, Lemma P. Methadone maintenance at different dosages for opioid dependence. Cochrane Database of Systematic Reviews 2003, Issue 1. [DOI: 10.1002/14651858.CD002208]

\section{Fareed 2012}

Fareed A, Vayalapalli S, Casarella J, Drexler K. Effect of buprenorphine dose on treatment outcome. Journal of Addiction Disorders 2012;31(1):8-18.

\section{Fiscella 2004}

Fiscella K, Moore A, Engerman J, Meldrum S. Jail management of arrestees/inmates enrolled in community methadone maintenance programs. Journal of Urban Health: Bulletin of the New York Academy of Medicine. 2004; 81:645-54.

\section{Garcia 2007}

Garcia CA, Correa GC, Viver AD, Hernandez BS, Kinlock TW, Gordon MS, et al. Buprenorphine-naloxone treatment for pre-release opiod dependent inmates in Puerto Rico.

Journal of Addiction Medicine 2007;1:126-32.

\section{Gibson 2007}

Gibson A, Degenhardt LJ. Mortality related to pharmacotherapies for opioid dependence: a comparative analysis of coronial records. Drug and Alcohol Review 2007; 26:405-10.

\section{Gowing 2009}

Gowing L, Ali R, White J. Buprenorphine for the management of opioid withdrawal. Cochrane Database of Systematic Reviews 2009, Issue 3. [DOI: 10.1002/ 14651858.CD002025.pub4]

\section{Gunn 1991}

Gunn J, Maden A, Swinton M. Treatment needs of prisoners with psychiatric disorders. British Medical Journal 1991;303:338-41.

\section{Hedrich 2011}

Hedrich D, Alves P, Farrell M, Stover H, Moller L, Mayet S. The effectiveness of opioid maintenance treatment in prison settings: a systematic review. Addiction 2011;107:501-17.

\section{Hergert 2005}

Hergert G. Methadone and buprenorphine added to the WHO list of essential medicines. HIV, AIDS Policy Law Review 2005;10:23-4.

\section{Higgins 2011}

Higgins JPT, Green S (editors). Cochrane Handbook for Systematic Reviews of Interventions 5.1.0 [updated March 2011]. The Cochrane Collaboration, 2011. Available from www.cochrane-handbook.org.

Lo 2000

Lo CC, Stephens RC. Drugs and prisoners: treatment needs on entering prison. American Journal of Drug and Alcohol Abuse 2000;26:229-45.

\section{Lobmaier 2008}

Lobmaier P, Kornor H, Kunoe N, Bjorndal A. Sustainedrelease naltrexone for opioid dependence. Cochrane Database of Systematic Reviews 2008, Issue 2. [DOI: 10.1002/14651858.CD006140.pub2]

\section{Magura 1995}

Magura S, Kang SY, Shapiro JL. Measuring cocaine use by hair analysis among criminally involved youth. Journal of Drug Issues 1995;25:683-701.

\section{Marsch 1998}

Marsch LA. The efficacy of methadone maintenance interventions in reducing illicit opiate use, HIV risk behaviours and criminality: a meta-analysis. Addiction 1998;93(4):515-32.

\section{Mason 1997}

Mason D, Birmingham L, Grubin D. Substance use in remand prisoners: a consecutive case study. British Medical Journal 1997;315:18-21.

\section{Mattick 2009}

Mattick RP, Breen C, Kimber J, Davoli M. Methadone maintenance therapy versus no opioid replacement therapy for opioid dependence. Cochrane Database 
of Systematic Reviews 2009, Issue 3. [DOI: 10.1002/ 14651858.CD002209.pub2]

\section{Michel 2005}

Michel L, Maguet O. Guidelines for substitution treatments in prison populations. Encephale 2005;31(1):92-7.

Minozzi 2011

Minozzi S, Amato L, Vecchi S, Davoli M, Kirchmayer U, Verster A. Oral naltrexone maintenance treatment for opioid dependence. Cochrane Database of Systematic Reviews 2011, Issue 2. [DOI: 10.1002/14651858.CD001333.pub3]

\section{Mitchell 2006}

Mitchell O, Wilson D, MacKenzie D. The effectiveness of incarceration-based drug treatment on criminal behaviour. Campbell Systematic Reviews 2006, issue 11. [DOI: 10.4073/csr.2006.11]

\section{Mitchell, 2012a}

Mitchell O, Mackenzie LD, Wilson D. The effectiveness of incarcerated based drug treatment on criminal behaviour: A systematic review. Campbell Systematic Reviews 2012; Vol. 18. [DOI: $10.4073 /$ csr.2012.18]

\section{Mitchell, 2012b}

Mitchell O, Wilson D, Eggers A, Mackenzie LD. Drug Courts effects on criminal offending for juveniles and adults: A systematic review. Campbell Systematic Reviews 2012; Vol. 4. [DOI: 10.4073/csr.2012.4]

\section{Moller 2007}

Moller L, Gathere A, Juergens R, Stover H, Nikogosian H. Health in Prisons. A WHO Guide to the Essentials in Prison Health. Copenhagen: World Health Organization Regional Office for Europe, 2007.

\section{NICE 2007a}

National Institute for Health and Clinical Excellence. NICE technology appraisal guidance 114 Methadone and buprenorphine for the management of opioid dependence. www.nice.org.uk/TA114. Accessed 20 July 2013. 2007. [: ISBN 1-84629-338-3]

\section{NICE 2007b}

National Institute for Health and Clinical Excellence. NICE technology appraisal guidance 115 Naltrexone for the management of opioid dependence. www.nice.org.uk/ TA115. Accessed 20 July 2013. 2007.

\section{Perry 2006}

Perry A, Coulton S, Glanville J, Godfrey C, Lunn J, McDougall C, et al. Interventions for drug-using offenders in the courts, secure establishments and the community. Cochrane Database of Systematic Reviews 2006, Issue 3. [DOI: 10.1002/14651858.CD005193.pub2]

\section{Perry 2013a}

Perry AE, Neilson M, Martyn-St James M, Hewitt C, Glanville J, McCool R, et al. Non-pharmacologic interventions for drug-using offenders. Cochrane Database of Systematic Reviews.

\section{Perry 2013b}

Perry AE, Neilson M, Martyn-St James M, Hewitt C, Glanville J, McCool R, et al. Interventions for drug using offenders with co-occurring mental illness. Cochrane Database of Systematic Reviews 2013.

\section{Perry 2013c}

Perry AE, Neilson M, Martyn-St James M, Hewitt C, Glanville J, McCool R, et al. Interventions for female drug using offenders. Cochrane Database of Systematic Reviews 2013.

\section{Review Manager 2014}

The Nordic Cochrane Centre, The Cochrane Collaboration. Review Manager (RevMan). 5.3. Copenhagen: The Nordic Cochrane Centre, The Cochrane Collaboration, 2014.

\section{Reynaud-Maurupt 2005}

Reynaud-Maurupt C, Caer Y, Escaffre N, Gagneau M, Galinier A, Marzo NJ, et al. High-dose buprenorphine substitution during incarceration. La Presse Médicale 2005; 34:487-90

\section{Stallwitz 2007}

Stallwitz A, Stover H. The impact of substitution treatment in prisons- a literature review. International Journal Drug Policy 2007; 18:464-74.

* Indicates the major publication for the study 


\section{CHARACTERISTICS OF STUDIES}

\section{Characteristics of included studies [ordered by study ID]}

\section{Bayanzadeh 2004}

Methods
Allocation: random assignment

Randomisation method: high risk based on even and odd rows

Similar on drug use: yes

Similar on criminal activity: unknown

Blinding methodology: high-risk participants not blind

Loss to follow-up: inadequate information with some attrition in the control group/high risk

$\begin{array}{ll}\text { Participants } & 120 \text { male participants } \\ 100 \% \text { male } \\ \text { Age range: } 20 \text { to } 70 \text { years } \\ \text { Mean age: } 35.7 \text { years (SD 8.86) } \\ \text { Participants had to have a history of opioid use for longer than one year, had to be } \\ \text { dependent upon drugs and had to have a sentence length greater than } 6 \text { months. In } \\ \text { addition, non-death penalty inmates were excluded, and individuals had to be willing to } \\ \text { engage in services }\end{array}$

Interventions

Intervention group:

The intervention group received methadone treatment in combination with CBT and widely focused on coping and problem-solving skills. $n=60$. The CBT training offered analysis on the role and thoughts on drug abuse, identification of high-risk situations, relapse prevention resilience skills, family participation in treatment and motivational interviewing. Family education was arranged to coincide with weekly visiting hours and the harm reduction education was delivered once a week

Comparison group:

The comparison group received non-methadone drugs plus standard psychiatric services and therapeutic medications. An option for treatment using clonidine and psychoactive drugs was provided as part of this treatment alternative $n=60$

$\begin{array}{ll}\text { Outcomes } & \text { Drug use: yes/no } \\ & \text { Frequency of drug injections (percentage) } \\ & \text { Syringe sharing } \\ \text { Morphine urine analysis } \\ \text { All outcomes at six months }\end{array}$

Notes

After random allocation, 20 participants who were allocated to the control group opted out of the research. This group of inmates were subsequently replaced by individuals from the general inmate population No conflict of interest was reported.

Risk of bias

Bias

Authors' judgement

Support for judgement 
Bayanzadeh 2004 (Continued)

\begin{tabular}{|c|c|c|}
\hline $\begin{array}{l}\text { Random sequence generation (selection } \\
\text { bias) }\end{array}$ & High risk & $\begin{array}{l}\text { Participants were categorised into one of } \\
\text { four lists based on their previous history } \\
\text { of drug abuse. The random allocation was } \\
\text { then chosen, using even and odd row num- } \\
\text { bers from each list }\end{array}$ \\
\hline Allocation concealment (selection bias) & Unclear risk & Not reported \\
\hline $\begin{array}{l}\text { Blinding of participants and personnel } \\
\text { (performance bias) } \\
\text { subjective outcomes }\end{array}$ & Unclear risk & No information reported \\
\hline $\begin{array}{l}\text { Blinding of participants and personnel } \\
\text { (performance bias) } \\
\text { objective outcomes }\end{array}$ & Unclear risk & No information reported \\
\hline $\begin{array}{l}\text { Blinding of outcome assessment (detection } \\
\text { bias) } \\
\text { subjective outcomes }\end{array}$ & Unclear risk & No information reported \\
\hline $\begin{array}{l}\text { Blinding of outcome assessment (detection } \\
\text { bias) } \\
\text { Objective outcomes }\end{array}$ & Unclear risk & No information reported \\
\hline $\begin{array}{l}\text { Incomplete outcome data (attrition bias) } \\
\text { All outcomes }\end{array}$ & High risk & $\begin{array}{l}\text { After random allocation, } 20 \text { participants } \\
\text { from the control group opted out of the } \\
\text { research. At the end of the study attrition } \\
\text { was high in both groups: for the interven- } \\
\text { tion group } n=38 \text { out of the original } 60 \\
\text { allocated and for the control group } n=31 \\
\text { out of the original } 60 \text { allocated }\end{array}$ \\
\hline Selective reporting (reporting bias) & Unclear risk & $\begin{array}{l}\text { Not clearly reported but problems with the } \\
\text { research design are highlighted }\end{array}$ \\
\hline Other bias & High risk & $\begin{array}{l}\text { The authors note a number of operational } \\
\text { difficulties, especially in relation to con- } \\
\text { tamination across prison wings and the two } \\
\text { intervention groups }\end{array}$ \\
\hline
\end{tabular}


Methods

Participants
Allocation: random assignment

Randomisation method: not reported

Similar on drug use: reported that there was no significant between-group difference in any demographic variable. Variable and data not presented

Similar on criminal activity: as above

Blinding methodology: unclear risk, not reported

Loss to follow-up: high risk, study retention rate reported as $80 \%$, but figure indicates $80 \%$ at week $24,33 \%$ at week 52 and $26 \%$ at follow-up

15 adults enrolled in either a drug treatment court (DTC) or Treatment Alternative Program (TAP). Participants were referred by the Clinical Assessment Unit at the Mental Health Centre of Dane County, where all potential jail diversion program participants receive initial clinical evaluation

Average age: 27.5 years

$53.3 \%$ male

$80.0 \%$ white

$\%$ drug users, not reported

$\%$ alcohol, not reported

$\%$ psychiatric history, not reported

Eligibility criteria: inclusion criteria were diagnosis of opioid dependence (via Mini International Neuropsychiatric Interview (MINI)), opioid positive urine drug screen, negative screening urine pregnancy test, and willingness to use appropriate birth control methods throughout the study. Exclusion criteria (via MINI and initial medical history and physical exam) were current alcohol or sedative dependence, pregnancy, women who were breastfeeding, complex psychiatric comorbidity, complex medical comorbidity, or pharmacotherapy with an agent contraindicated in combination with suboxone or methadone, according to drug labelling

Interventions

Interventions:

(I) specialist treatment facility plus suboxone (buprenorphine and naloxone)

or (ii) specialist treatment facility plus methadone, $\mathrm{n}=9$

Control:

(C) primary care plus suboxone (buprenorphine and naloxone), $\mathrm{n}=6$

Participation lasted 13.5 months, including a 12-month treatment period and a onetime follow-up 6 weeks post-treatment

Outcomes

Primary outcomes included on-going drug use measured by timeline follow-back method (TLFB is a reliable, calendar-based technique for retrospectively assessing the frequency and patterns of daily drug use) and use of the Addiction Severity Index (self report)

Lite, HIV risk behaviours (RAB - Risk Assessment Battery short version), and health services utilization. TLFB was administered at baseline, bi-weekly for the first 6 months, and monthly thereafter. All other measures were assessed at baseline, month 6 , month 12 , and follow-up

Urine drug screens were collected as a part of routine management in DTC and TAP

Notes

The project described was supported by the Clinical and Translational Science Award (CTSA) program, previously through the National Center for Research Resources (NCRR - now the National Centre for Advancing Translational Sciences, NCATS) grant 
Brown 2013 (Continued)

1UL1RR025011, and grant 9U54TR000021. Funding was also provided by the Vilas Foundation

The authors report no conflicts of interest.

\section{Risk of bias}

\begin{tabular}{l|l|l} 
Bias & Authors' judgement & Support for judgement \\
\hline $\begin{array}{l}\text { Random sequence generation (selection } \\
\text { bias) }\end{array}$ & Unclear risk & $\begin{array}{l}\text { Random allocation noted no further infor- } \\
\text { mation. }\end{array}$ \\
\hline $\begin{array}{l}\text { Allocation concealment (selection bias) } \\
\text { Blinding of participants and personnel } \\
\text { (performance bias) } \\
\text { subjective outcomes }\end{array}$ & Unclear risk & No information provided \\
\hline
\end{tabular}

Blinding of participants and personnel Unclear risk

No information provided

(performance bias)

objective outcomes

Blinding of outcome assessment (detection Unclear risk bias)

subjective outcomes

Blinding of outcome assessment (detection Unclear risk bias)

Objective outcomes
Incomplete outcome data (attrition bias) High risk

All outcomes

Selective reporting (reporting bias)

High risk
No information provided

No information provided$$
\text { No information provided. }
$$

Small sample size (reported as a "pilot study") with $80 \%$ completing the 24 -week assessment, 33\% completing week 52 and $26 \%$ at follow-up

Protocol reported as being available. However, on-going drug use (frequency and patterns of daily drug use), health services utilization and urine tests are reported as being assessed, but no outcome data are reported

Other bias $\quad$ High risk

The authors report: "The higher baseline HIV risk in the specialist study condition, and, hence, greater potential for risk reduction, may have affected this result. In other words, the relatively low prevalence of global HIV risk behaviours in the primary care group may have contributed to a 'floor effect' or greater difficulty achieving 
Brown 2013 (Continued)

improvement on this factor."

"Additionally, urine drug testing was not collected randomly DTC and TAP where severity of use affects frequency of testing. Hence, urine drug test results are likely to present a biased picture and be difficult to interpret in aggregate in this communitybased setting."

\section{Cornish 1997}

\begin{tabular}{|c|c|}
\hline Methods & $\begin{array}{l}\text { Allocation: random assignment, 2:1 ratio (naltrexone:control) } \\
\text { Randomisation method: unclear } \\
\text { Similar on drug use: yes } \\
\text { Similar on criminal activity: unknown } \\
\text { Blinding methodology: high risk } \\
\text { Loss to follow-up: unclear risk; some loss to follow-up; volunteer participants }\end{array}$ \\
\hline Participants & $\begin{array}{l}51 \text { adults randomized, } 68 \text { indicated initial interest, of these } 2 \text { failed the naltrexone } \\
\text { challenge and } 15 \text { did not return for completion of screening and enrollment } \\
\text { Average age: } 39 \text { years } \\
90 \% \text { male } \\
24 \% \text { white } \\
62 \% \text { African American } \\
14 \% \text { Latino }\end{array}$ \\
\hline Interventions & $\begin{array}{l}\text { Community-based naltrexone programme and routine parole/probation }(\mathrm{n}=34) \text { vs } \\
\text { routine parole/probation }(\mathrm{n}=17) \\
\text { (I) Nalrexone programe: When a } 0.8 \text { naltrexone challenge was negative, the participant } \\
\text { received } 25 \mathrm{mg} \text { oral dose of naltrexone, if no signs of opioid withdrawal after } 1 \text { hour, this } \\
\text { was followed by } 25 \mathrm{mg} \text { daily for two days and } 50 \mathrm{mg} \text { daily for the following three days. } \\
\text { Aproximately } 1 \text { week after initiation participants were stabilized on naltrexone regimen } \\
\text { of } 100 \mathrm{mg} \text { on Tuesdays and } 150 \mathrm{mg} \text { on Fridays. In addition, research staff obtained } \\
\text { observed urine specimens and breathalyzer readings weekly (results of these were not } \\
\text { shared with probation staff) } \\
\text { (C) Routine parole/probation: Participants were required to attend three orientation and } \\
\text { counseling sessions per week for the first } 2 \text { weeks of the study } \\
\text { Both groups received weekly parole/probation officer contact for the first } 6 \text { months and } \\
\text { medication visits occured twice weekly. At } 6 \text {-month follow up participants were give a } \\
\$ 25 \text { incentive payment and at } 9,12,15 \text { and } 18 \text { month follow up participants were given } \\
\$ 25 \text { for keeping scheduled appointments }\end{array}$ \\
\hline
\end{tabular}

Outcomes

Reincarceration for technical violation (official records) during the past 6 months at 6 months' follow-up

Mean percentage for opioid positive urine specimens per group

Notes

Work supported by NIDA Grant DA05186.

No declarations of interest are noted by the authors

Pharmacological interventions for drug-using offenders (Review)

Copyright () 2015 The Cochrane Collaboration. Published by John Wiley \& Sons, Ltd. 


\section{Cornish 1997 (Continued)}

\section{Risk of bias}

\begin{tabular}{|c|c|c|}
\hline Bias & Authors' judgement & Support for judgement \\
\hline $\begin{array}{l}\text { Random sequence generation (selection } \\
\text { bias) }\end{array}$ & Low risk & $\begin{array}{l}\text { Individuals were assigned at a ratio of } 2: 1 \\
\text { to naltrexone vs control }\end{array}$ \\
\hline Allocation concealment (selection bias) & Unclear risk & Not reported \\
\hline $\begin{array}{l}\text { Blinding of participants and personnel } \\
\text { (performance bias) } \\
\text { subjective outcomes }\end{array}$ & High risk & $\begin{array}{l}\text { Study description suggests that participants } \\
\text { were not blind: see p. } 531\end{array}$ \\
\hline $\begin{array}{l}\text { Blinding of participants and personnel } \\
\text { (performance bias) } \\
\text { objective outcomes }\end{array}$ & High risk & $\begin{array}{l}\text { Study description suggests that participants } \\
\text { were not blind: see p. } 531\end{array}$ \\
\hline $\begin{array}{l}\text { Blinding of outcome assessment (detection } \\
\text { bias) } \\
\text { subjective outcomes }\end{array}$ & Unclear risk & No information reported \\
\hline $\begin{array}{l}\text { Blinding of outcome assessment (detection } \\
\text { bias) } \\
\text { Objective outcomes }\end{array}$ & Low risk & $\begin{array}{l}\text { Blinding of urine samples were not shared } \\
\text { with probation staff }\end{array}$ \\
\hline $\begin{array}{l}\text { Incomplete outcome data (attrition bias) } \\
\text { All outcomes }\end{array}$ & Low risk & $\begin{array}{l}\text { All allocated participants were reported in } \\
\text { the analysis. Retention rates appeared to be } \\
\text { similar; appears to be an ITT analysis }\end{array}$ \\
\hline Selective reporting (reporting bias) & Unclear risk & Not reported \\
\hline Other bias & Unclear risk & $\begin{array}{l}\text { Groups similar at baseline, but potential for } \\
\text { volunteer bias }\end{array}$ \\
\hline
\end{tabular}

Coviello 2010

\begin{tabular}{ll} 
Methods & Allocation: random \\
& Randomisation method: unknown/unclear \\
& Similar on drug use: significant difference in heroin use. Otherwise similar \\
& Similar on criminal activity: yes \\
& Blinding methodology: high risk \\
& Loss to follow-up: inadequate/high risk \\
\hline Participants & 111 adults \\
& $\begin{array}{l}\text { Age range: } 18 \text { to } 55 \text { years; average age: } 34 \text { years } \\
82 \% \text { male } \\
47 \% \text { Caucasian }\end{array}$ \\
\hline
\end{tabular}


Coviello 2010 (Continued)

\begin{tabular}{|c|c|}
\hline & $\begin{array}{l}100 \% \text { drug users } \\
\text { Alcohol use not reported but participants excluded if severe alcohol dependence } \\
\text { Psychiatric history not reported } \\
\text { Eligibility criteria: consented, age } 18 \text { to } 55 \text { years, opioid dependence, otherwise good } \\
\text { health, probation or parole for } 6 \text { months, } 3 \text { days opioid free }\end{array}$ \\
\hline Interventions & $\begin{array}{l}\text { Community pharmacological intervention vs treatment as usual } \\
\text { (I) Oral naltrexone plus psychosocial treatment }(n=56) \text { vs }(\mathrm{C}) \text { psychosocial treatment } \\
\text { only }(\mathrm{n}=55) \\
\text { The (I) group was started on directly observed administration of naltrexone, increasing } \\
\text { in dose from } 25 \mathrm{mg} \text { to } 300 \mathrm{mg} \text { and was also given psychosocial treatment. The }(\mathrm{C}) \text { group } \\
\text { was given a treatment regimen consisting of group therapy, individual therapy and case } \\
\text { management, all of which the (I) group also received }\end{array}$ \\
\hline Outcomes & $\begin{array}{l}\text { Criminal activity (self-reported) and criminal record data at } 6 \text { months } \\
\text { Illicit drug use (self-reported) during the } 30 \text { days before the interview at } 6 \text { months } \\
\% \text { positive urine drug screen for opioids } \\
\% \text { positive urine drug screen for cocaine }\end{array}$ \\
\hline Notes & $\begin{array}{l}\text { The study was supported by grant R01-DA- } 012268 \text { from the National Institute on Drug } \\
\text { Abuse, Bethesda, MD (Dr. Cornish) } \\
\text { Declaration of Interest In the past } 3 \text { years, Dr. O'Brien has served as a consultant on one } \\
\text { occasion to Alkermes, a company that makes a version of depot naltrexone. He is also } \\
\text { conducting an NIH-funded study of this medication in opioid addiction. The authors } \\
\text { report no conflicts of interest }\end{array}$ \\
\hline
\end{tabular}

Risk of bias

Bias

Random sequence generation (selection Unclear risk bias)

\section{Support for judgement}

Randomisation method unclear. Note that randomisation was balanced by using six variables

No information provided

page 4 'we did not use a placebo for participants'. The treatment as usual group were not blinded

page 4 'we did not use a placebo for participants'. The treatment as usual group were not blinded

No information provided

Blinding of outcome assessment (detection Unclear risk bias)

subjective outcomes

Pharmacological interventions for drug-using offenders (Review) 
Coviello 2010 (Continued)

\begin{tabular}{l|l|l}
$\begin{array}{l}\text { Blinding of outcome assessment (detection } \\
\text { bias) } \\
\text { Objective outcomes }\end{array}$ & Unclear risk & No information provided \\
\hline $\begin{array}{l}\text { Incomplete outcome data (attrition bias) } \\
\text { All outcomes }\end{array}$ & High risk & $\begin{array}{l}\text { A large amount of attrition was noted in } \\
\text { the first week, and only one-third of par- } \\
\text { ticipants remained at 6-month follow-up }\end{array}$ \\
\hline Selective reporting (reporting bias) & Unclear risk & No information provided \\
\hline Other bias & High risk & Blinding and attrition concerns through- \\
\hline
\end{tabular}

Cropsey 2011

Methods

Allocation: random assignment, random number table- first 9 people put on intervention Randomisation method: sealed envelopes opened at the end of treatment

Similar on drug use: yes

Similar on criminal activity: yes

Blinding methodology: double-blinded. Placebo was used and was not known to evaluators or dispensers during treatment

Loss to follow-up: partial- a few individuals not included in the final analysis

Participants

36 adults

Mean age: 31.8 years (SD 8.4)

$100 \%$ female

$89 \%$ white

100 drug users

Alcohol use: yes- percentage not available

$54.3 \%$ prescribed medication for mental illness

Eligibility criteria: adult women, opioid dependent, interest in treatment for opioid dependence, no contraindications for buprenorphine, due for release from residential treatment within the month, returning to the community, release to correct area

Interventions

Community-based pharmacological intervention vs placebo

(I) buprenorphine ( $\mathrm{n}=24)$ vs $(\mathrm{C})$ placebo $(\mathrm{n}=12)$

(I) group was started on $2 \mathrm{mg}$ of buprenorphine, increased to target dose of $8 \mathrm{mg}$ at discharge. Only 37.2\% reached target dose at discharge. (Doses were lower than standard induction, as participants had been in a controlled environment for some time without access to opiates.) Doses were titrated up to a maximum of $32 \mathrm{mg}$ per day in the community, as clinically indicated. Participants were assessed weekly for side effects, were given drug testing and were counselled by the study physician if using drugs. The treatment course was 12 weeks

The (C) group was given a placebo on the same regimen as the (I) group

Outcomes

$\%$ injection drug use and \% urine opiates at end of treatment and at 3 months' followup

Pharmacological interventions for drug-using offenders (Review) 


\section{Cropsey 2011 (Continued)}

$\begin{array}{ll}\text { Notes } & \text { This project was supported by funding from NIDA R21DA019838 } \\ \text { and product support from Reckitt Benckiser Pharmaceuticals Inc } \\ \text { The authors have no declarations of interest }\end{array}$

Risk of bias

\begin{tabular}{l|l|l}
\hline Bias & Authors' judgement & Support for judgement \\
\hline $\begin{array}{l}\text { Random sequence generation (selection } \\
\text { bias) }\end{array}$ & High risk & $\begin{array}{l}\text { First 9 participants deliberately allocated to } \\
\text { intervention for practical reasons; use of a } \\
\text { random number table }\end{array}$ \\
\hline Allocation concealment (selection bias) & Low risk & Use of sealed envelopes \\
\hline $\begin{array}{l}\text { Blinding of participants and personnel } \\
\text { (performance bias) } \\
\text { subjective outcomes }\end{array}$ & Unclear risk & $\begin{array}{l}\text { This trial began as an open label trial then } \\
\text { became a double blind trial of participants } \\
\text { and providers on all outcomes. Some con- } \\
\text { cerns about contamination issues with the } \\
\text { placebo group but difficult to assess to what } \\
\text { extent the blinding might have been af- } \\
\text { fected }\end{array}$ \\
\hline
\end{tabular}

Blinding of participants and personnel Unclear risk (performance bias) objective outcomes
This trial began as an open label trial then became a double blind trial of participants and providers on all outcomes. Some concerns about contamination issues with the placebo group but difficult to assess to what extent the blinding might have been affected

No evidence to provide information about whether the assessors were blind bias)

Unclear risk

subjective outcomes
No evidence to provide information about whether the assessors were blind bias)

Objective outcomes

Incomplete outcome data (attrition bias) Unclear risk All outcomes

\begin{tabular}{|c|c|c|}
\hline Selective reporting (reporting bias) & Unclear risk & No information reported \\
\hline Other bias & Low risk & No other concerns within the methodology \\
\hline
\end{tabular}


Randomisation method: low risk, cards drawn from sealed envelope

Similar on drug use: yes

Similar on criminal activity: yes

Blinding methodology: high risk, treatment and comparator (methadone or wait list) would not permit blinding. No statement that the outcome assessment was blind (unclear risk)

Loss to follow-up: high risk, $>30 \%$ in both groups excluded from 4-month follow-up

Participants

382 adults and young offenders

Mean age: 27 years (SD 6)

$100 \%$ male

Ethnicity: not reported

$100 \%$ drug-using

Alcohol use: not reported

Psychiatric history: not reported

Eligibility criteria: prisoners with a heroin problem, as confirmed by a detailed interview, who have at least 4 months remaining on their prison sentence at time of interview

(I) Participants were given $30 \mathrm{mg}$ of methadone each day, increasing by $5 \mathrm{mg}$ every 3 days until $60 \mathrm{mg}$ was achieved; duration in treatment varied. Duration of waiting-list was 4 months

At 5 months, all participants were offered methadone through the prison-based methadone treatment programme. Released subjects who had been treated through the prison methadone programme were offered the opportunity to transfer to local community methadone programmes

\section{Dolan 2003: primary study}

Heroin use (hair analysis) and self-reported heroin use during the past 2 months at 2 months' follow-up

Drug injecting during the past 3 months at 3 months' follow-up.

Syringe sharing and HIV/HCV seroconversion during the past 4 months at 4 months' follow-up

\section{Dolan 2005: 4-year follow up}

Long-term outcomes at four years including mortality, reincarceration, hepatitis C seroconversion and HIV seroconversion vices, Glaxo Wellcome, the NSW Department of Health and the National Drug and Alcohol Research Centre, UNSW

The authors have no declarations of interest

\section{Risk of bias}


Dolan 2003 (Continued)

\begin{tabular}{|c|c|c|}
\hline $\begin{array}{l}\text { Random sequence generation (selection } \\
\text { bias) }\end{array}$ & Low risk & Central randomisation by phone \\
\hline Allocation concealment (selection bias) & Low risk & $\begin{array}{l}\text { Allocation held by researcher not involved } \\
\text { in recruiting or interviewing participants. } \\
\text { Trial nurses had no access to lists }\end{array}$ \\
\hline $\begin{array}{l}\text { Blinding of participants and personnel } \\
\text { (performance bias) } \\
\text { subjective outcomes }\end{array}$ & Unclear risk & $\begin{array}{l}\text { Treatment and comparator (methadone or } \\
\text { wait list) would not permit blinding }\end{array}$ \\
\hline $\begin{array}{l}\text { Blinding of participants and personnel } \\
\text { (performance bias) } \\
\text { objective outcomes }\end{array}$ & Unclear risk & $\begin{array}{l}\text { Treatment and comparator (methadone or } \\
\text { wait list) would not permit blinding }\end{array}$ \\
\hline $\begin{array}{l}\text { Blinding of outcome assessment (detection } \\
\text { bias) } \\
\text { subjective outcomes }\end{array}$ & Unclear risk & No information provided \\
\hline $\begin{array}{l}\text { Blinding of outcome assessment (detection } \\
\text { bias) } \\
\text { Objective outcomes }\end{array}$ & Unclear risk & No information provided \\
\hline $\begin{array}{l}\text { Incomplete outcome data (attrition bias) } \\
\text { All outcomes }\end{array}$ & High risk & $\begin{array}{l}\text { Attrition }>30 \% \text { in both groups and ITT } \\
\text { not undertaken. At follow-up, } 129(68 \%) \\
\text { treated and } 124(65 \%) \text { control subjects } \\
\text { who had been in continuous custody were } \\
\text { reinterviewed. } 29 \text { treated and } 33 \text { control } \\
\text { subjects had been released from prison and } \\
\text { were excluded. No data on other partici- } \\
\text { pants not accounted for at follow-up }\end{array}$ \\
\hline Selective reporting (reporting bias) & Low risk & $\begin{array}{l}\text { All outcomes in objectives were reported in } \\
\text { results }\end{array}$ \\
\hline Other bias & Low risk & $\begin{array}{l}\text { Baseline characteristics largely similar ( } \mathrm{p} \\
61 \text { ) } \\
\text { Some control participants received } \mathrm{Tx} \text {, } \\
\text { some Tx not given; methadone tested by } \\
\text { subgroup analysis }\end{array}$ \\
\hline
\end{tabular}


Similar on drug use: yes

Similar on criminal activity: yes

Blinding methodology: unclear and not reported

Loss to follow-up: adequate/low risk

\begin{tabular}{ll}
\hline Participants & 32 males \\
& $\begin{array}{l}\text { Heroin addicts } 5 \text { years or longer } \\
5 \text { or more previous convictions } \\
15 \text { European, } 10 \text { negro, } 7 \text { Puerto Rican } \\
\text { With a population of heroin-dependent prerelease prisoners }\end{array}$ \\
\hline Interventions & $\begin{array}{l}\text { Methadone (n }=12) \text { vs waiting-list control ( } \mathrm{n}=16) . \\
\text { Methadone was prescribed on admission to a hospital unit where individuals were given } \\
10 \text { mg per day, gradually increasing to a dose of } 35 \text { mg }\end{array}$ \\
\hline Outcomes & $\begin{array}{l}\text { Heroin use } \\
\text { Reincarceration } \\
\text { Treatment retention } \\
\text { Employment } \\
\text { At } 7 \text { to } 10 \text { months, } 50 \text { weeks }\end{array}$ \\
\hline Participants were chosen by a lottery based on release dates between January 1 and April \\
$\begin{array}{l}301968 \\
\text { Supported by grants from the Health Research Council and the New York State Narcotics } \\
\text { Addiction Control Commission } \\
\text { No declarations of interest by the authors }\end{array}$ \\
\hline
\end{tabular}

\section{Risk of bias}

\begin{tabular}{l|ll}
\hline Bias & Authors' judgement & Support for judgement \\
\hline $\begin{array}{l}\text { Random sequence generation (selection } \\
\text { bias) }\end{array}$ & Low risk & $\begin{array}{l}\text { Allocation by lottery, no further details of } \\
\text { the study method provided }\end{array}$ \\
\hline $\begin{array}{l}\text { Allocation concealment (selection bias) } \\
\begin{array}{l}\text { Blinding of participants and personnel } \\
\text { (performance bias) } \\
\text { subjective outcomes }\end{array}\end{array}$ & Unclear risk & Not reported \\
\hline $\begin{array}{l}\text { Blinding of participants and personnel } \\
\text { (performance bias) } \\
\text { objective outcomes }\end{array}$ & Unclear risk & No information provided \\
\hline
\end{tabular}

Blinding of outcome assessment (detection Unclear risk

No information provided bias)

subjective outcomes 
Dole 1969 (Continued)

\begin{tabular}{|c|c|c|}
\hline $\begin{array}{l}\text { Blinding of outcome assessment (detection } \\
\text { bias) } \\
\text { Objective outcomes }\end{array}$ & Unclear risk & No information provided \\
\hline $\begin{array}{l}\text { Incomplete outcome data (attrition bias) } \\
\text { All outcomes }\end{array}$ & Low risk & No missing data on key outcomes \\
\hline Selective reporting (reporting bias) & Unclear risk & Intention-to-treat analysis not reported \\
\hline Other bias & Unclear risk & $\begin{array}{l}\text { Representativeness of the small sample with } \\
\text { no urine analysis in follow-up of controls }\end{array}$ \\
\hline
\end{tabular}

Howells 2002

Methods

Allocation: random assignment

Randomisation method: method not reported

Similar on drug use: yes

Similar on criminal activity: not reported

Blinding methodology: low risk, double-blind with blinded outcome assessment

Loss to follow-up: high risk, 21 participants (27.63\%) (13/32 lofexidine, 8/36 metha-

done) were withdrawn from the trial prematurely

Participants

80 adult participants was planned, in the time available for the trial, 76 patients met eligibility criteria and gave their consent to participate. Of these, two patients immediately elected to withdraw from the trial. In error, six patients were entered into the trial for a second detoxification after completing the trial on the first occasion and then receiving a separate prison sentence following release. Four of these patients were randomised to the other drug on second entry

Average age: The ages of the lofexidine and methadone groups were similar (29.8 years [range 22 to 43 ] and 30.5 years [range 22 to 49 ] respectively, $\mathrm{P}=0.65$ )

$100 \%$ male

$\%$ white not reported

Use of heroin was reported by $97.1 \%(n=66)$ of the participants during the previous month and $89.7 \%$ reported heroin to be their main problem substance

$\%$ alcohol not reported

$\%$ psychiatric history not reported. Major psychiatric illness was an exclusion criterion Eligibility criteria: Consenting patients were required to be under 55 years old and to meet DSM-IV criteria for opioid dependence and induced withdrawal (American Psychiatric Association, 1994). Participant exclusion criteria were concurrent serious major psychiatric illness (schizophrenia, psychotic depression) or serious physical illness that would prevent participation in the trial. Opioid use was confirmed by urine screening for the presence of urinary opioid metabolites

Interventions

Intervention:

(I) Placebo syrup as a green aqueous solution and lofexidine peach-coloured tablets twice daily for 10 days $(\mathrm{n}=32)$

Control:

(C) Methadone as a green liquid $(1 \mathrm{mg} / \mathrm{ml})$, and placebo peach-coloured tablets, twice

Pharmacological interventions for drug-using offenders (Review) 
Howells 2002 (Continued)

daily for 10 days

Following the manufacturer's datasheet the Lofexidine (Britlofex) regimen consisted of an initial daily dose of $0.6 \mathrm{mg}$ (with $0.2 \mathrm{mg}$ administered in the morning and $0.4 \mathrm{mg}$ at night) increasing by $0.4 \mathrm{mg}$ daily (two tablets) until day 4 . At this point the dose was maintained at $2 \mathrm{mg}$ daily (five tablets twice a day) for 3 days. Over the next 3 days the dose was tapered by $0.4 \mathrm{mg}$ per day. The gradual dose reduction was designed to prevent any possible rebound hypertension $(\mathrm{n}=36)$

Outcomes

The primary outcome measure was withdrawal symptom severity measured using two withdrawal scales: the 20-item Withdrawal Problems Scale (WPS), and the eight item Short Opiate Withdrawal Scale (SOWS). The participants self-completed the withdrawal scales each morning. Given limited item overlap between the two scales, a composite 28 item total withdrawal symptoms scale was computed to facilitate presentation of results. To analyse the total daily scores for each scale, the following global indices were derived: the highest daily score observed and the time of the occurrence, the lowest daily score observed and the time of the occurrence, the total score summed over all 10 days of the trial

Secondary outcome measures were rates and timing of withdrawal from the detoxification programme so that the relationship between failure to complete detoxification and severity of withdrawal symptoms could be measured

The Severity of Dependency Scale (SDS) was also used to assess the severity of psychological aspects of drug dependence

Notes

Britannia Pharmaceuticals provided the medication.

No declarations of interest statement included in the trial report

Risk of bias

\begin{tabular}{|c|c|c|}
\hline Bias & Authors' judgement & Support for judgement \\
\hline $\begin{array}{l}\text { Random sequence generation (selection } \\
\text { bias) }\end{array}$ & Unclear risk & $\begin{array}{l}\text { The authors report "The pharmacist who } \\
\text { made up the medication used a simple ran- } \\
\text { domisation procedure to allocate each par- } \\
\text { ticipant to one arm of the trial" but no fur- } \\
\text { ther description is reported }\end{array}$ \\
\hline
\end{tabular}

Allocation concealment (selection bias) Unclear risk

The authors report "The independent pharmacy team at the prison oversaw the randomisation and blinding procedure...", but no statement that allocation was concealed

Blinding of participants and personnel Low risk (performance bias)

“...both the patient and health centre clinsubjective outcomes icians were blind to the assigned treatment group"

Blinding of participants and personnel Low risk (performance bias)

objective outcomes

The authors report "The independent pharmacy team at the prison oversaw the randomisation and blinding procedure...",

Pharmacological interventions for drug-using offenders (Review)

Copyright @ 2015 The Cochrane Collaboration. Published by John Wiley \& Sons, Ltd. 
Howells 2002 (Continued)

but no statement that allocation was concealed

Blinding of outcome assessment (detection Low risk bias)

subjective outcomes

Blinding of outcome assessment (detection Low risk bias)

Objective outcomes

Incomplete outcome data (attrition bias) High risk

All outcomes

Selective reporting (reporting bias)

Low risk

High risk “...blinding was maintained during treatment of the patients and during data entry and analysis"

“...blinding was maintained during treatment of the patients and during data entry and analysis"

Twenty-one participants (27.63\%) (13/32 lofexidine, 8/36 methadone) were withdrawn from the trial prematurely. ITT not used, data analysed per-protocol

The authors indicate that there was a protocol for the study ("Patient safety elements in the protocol were as follows:") and primary and secondary outcomes are clearly defined. Outcome data for the primary and secondary outcomes are reported

The authors report "Four of these patients were randomised to the other drug on second entry. As a check on results, we repeated the analyses with the exclusion of these six cases. Whilst both the direction and magnitude of the results were unaltered we removed these cases from the dataset and the remaining results relate to the reduced sample of 68 patients."

Kinlock 2005

Methods

Allocation: random assignment

Randomisation method: unclear

Similar on drug use: yes

Similar on criminal activity: yes

Blinding methodology: unknown

Loss to follow-up: inadequate/high risk

Participants

126 adult males

Age: 35.7 years (SD 6.8)

$100 \%$ male

$14 \%$ white

$100 \%$ drug users

Alcohol use: not reported

Pharmacological interventions for drug-using offenders (Review)

Copyright @ 2015 The Cochrane Collaboration. Published by John Wiley \& Sons, Ltd. 
Kinlock 2005 (Continued)

Eligibility criteria: 3 months before anticipated release from prison, history of heroin dependence meeting DSM-IV criteria

Interventions

(I) Prison/secure establishment-based levo-alpha-acetyl methanol + transfer to methadone maintenance after release $(n=20)$ vs $(C)$ untreated controls $(31)$ and withdrew before treatment $(\mathrm{N}=13)$

(I) Participants medicated 3 times per week starting at $10 \mathrm{mg}$ and increasing by $5 \mathrm{mg}$ every third medication day during incarceration to a target dose of $50 \mathrm{mg}$. At release participants were advised to report to the program's communirty ased maintenance facility for continuing care

(C) Received community treatment referral information only.

Outcomes

Heroin use during 9-month follow-up (self-report), arrests during 9-month follow-up (official records) and reincarceration during 9-month follow-up (official records), frequency of illegal activity, admission to drug use and average weekly income obtained from illegal activities, mean number of crime days

Notes

No funding information provided

No declaration of interest by the authors

\section{Risk of bias}

$\begin{array}{lll}\text { Bias } & \text { Authors' judgement } & \text { Support for judgement }\end{array}$

Random sequence generation (selection Unclear risk

No information reported other than stated bias) 'random'

\begin{tabular}{l|ll} 
Allocation concealment (selection bias) & Unclear risk & No information reported \\
\hline $\begin{array}{l}\text { Blinding of participants and personnel } \\
\text { (performance bias) } \\
\text { subjective outcomes }\end{array}$ & Unclear risk & No information reported \\
\hline
\end{tabular}

Blinding of participants and personnel Unclear risk No information reported (performance bias)

objective outcomes

Blinding of outcome assessment (detection Unclear risk bias)

subjective outcomes

Blinding of outcome assessment (detection Unclear risk bias)

Objective outcomes

Incomplete outcome data (attrition bias) High risk All outcomes
A considerable number of experimental participants declined medication after initial consent and randomisation to the ex- 
Kinlock 2005 (Continued)

\begin{tabular}{|l|l|l|l}
\hline & $\begin{array}{l}\text { perimental condition (see pp. } 437 \text { and } \\
\text { 499). High attrition from the experimen- } \\
\text { tal group after random assignment and be- } \\
\text { fore treatment initiation required revision } \\
\text { of the original two-group study design for } \\
\text { purposes of data analyses }\end{array}$ \\
\hline Selective reporting (reporting bias) & High risk & $\begin{array}{l}\text { Table 4, p. 446, indicates only selected out- } \\
\text { comes. No ITT conducted }\end{array}$ \\
\hline Other bias & High risk & $\begin{array}{l}\text { Experimental and control groups could not } \\
\text { be considered comparable (p. 449); there- } \\
\text { fore, the number of variables was restricted. } \\
\text { Study groups were revised after attrition in } \\
\text { treatment group. Groups were considered } \\
\text { not to be comparable, and the number of } \\
\text { variables assessed was restricted. Urine sam- } \\
\text { ples and treatment records available on ex- } \\
\text { perimental group only }\end{array}$ \\
\hline
\end{tabular}

Kinlock 2007

Methods

Allocation: random assignment

Randomisation method: block randomised

Similar on drug use: unknown

Similar on criminal activity: unknown

Blinding methodology: high risk

Loss to follow-up: adequate

Participants

211 adult males

Age: group (a) 40.9 years (SD 7.6), (b) 40.3 years (7.0), (c) 39.8 years (7.0)

$100 \%$ male

$\%$ white: group (a) $31.3 \%$, (b) $19.7 \%$, (c) $20 \%$

$100 \%$ drug users

Alcohol use not reported

Psychiatric history not reported

Eligibility criteria:

(1) 3 to 6 months before release from prison; (2) meeting Diagnostic and Statistical Manual of Mental Disorders (DSM-IV) criteria of heroin dependence at time of incarceration and being physiologically dependent during the year prior to incarceration; (3) no pending parole hearings and/or unadjudicated charges; (4) having a Baltimore city address post-release; and (5) suitability for methadone maintenance as determined by medical evaluation. Inmates were excluded from study participation if they had any unadjudicated charges and/or pending parole hearings

Interventions

(C) Counselling Only: counselling in prison and passive referral to community-based drug treatment $(\mathrm{n}=70)$

(I) Counselling + Transfer: counselling in prison and transfer to methadone maintenance in the community upon release beginning with $5 \mathrm{mg}$ of methadone and increasing by 5

Pharmacological interventions for drug-using offenders (Review) 
Kinlock 2007 (Continued)

mg every eighth day to a target minimum dose of $60 \mathrm{mg}(\mathrm{n}=70)$

(I) Counselling + Methadone: counselling and methadone in prison with transfer to methadone treatment in the community upon release, begininning with $5 \mathrm{mg}$ dose of methadone and increasing by $5 \mathrm{mg}$ every eighth day during incarceration to a target dose of $60 \mathrm{mg}$. Advised to report to the program's community-based methadone program within 10 days of release for continuing care $(n=71)$

Outcomes

Kinlock 2007: primary study

Urine test for opioids 1 month post-release, urine test for cocaine 1 month post-release, self-report heroin use 1 month post-release, self-report cocaine use 1 month post-release Gordon 2008: 6 month follow up study

Urine testing for opioids, cocaine and other illicit drugs 6 months post-release, treatment record review, Addiction Severity Index (ASI) from baseline and follow up

Wilson 2012: follow up study

Post-release changes over time in the specific HIV risk behaviours in which the participants had a prior history of engaging. Participants were assessed at baseline (study entry in prison), and at 1-, 3-, 6-, and 12-month post-release. The primary outcome measures at each time period were self-reported participation in risky drug- and sex-risk behaviours obtained from the Texas Christian University AIDS Risk Assessment (ARA)

Notes

Funding for this study was provided by Grant R01 DA 16237 from the National Institute on Drug Abuse (NIDA)

No declarations of interest reported by the authors.

\section{Risk of bias}

Bias

Authors' judgement

Support for judgement

Random sequence generation (selection Low risk

Block randomisation

bias)

Allocation concealment (selection bias) Unclear risk

No information reported

Blinding of participants and personnel Unclear risk

No information reported

(performance bias)

subjective outcomes

Blinding of participants and personnel Unclear risk

No information reported

(performance bias)

objective outcomes

Blinding of outcome assessment (detection Unclear risk

No information reported

bias)

subjective outcomes

Blinding of outcome assessment (detection Unclear risk

bias)

Objective outcomes

Pharmacological interventions for drug-using offenders (Review)

Copyright (c) 2015 The Cochrane Collaboration. Published by John Wiley \& Sons, Ltd. 
Kinlock 2007 (Continued)

\begin{tabular}{|c|c|c|}
\hline $\begin{array}{l}\text { Incomplete outcome data (attrition bias) } \\
\text { All outcomes }\end{array}$ & High risk & $\begin{array}{l}\text { Individuals in the counselling only group } \\
\text { did not receive treatment }\end{array}$ \\
\hline Selective reporting (reporting bias) & Unclear risk & No information reported \\
\hline Other bias & High risk & Contamination of treatment groups \\
\hline
\end{tabular}

Lobmaier 2010

Methods

Allocation: random

Randomisation method: permuted block protocol

Groups similar on drug use at baseline: yes

Groups similar on criminal activity at baseline: yes

Blinding methodology: not blinded- open label

Loss to follow-up: unknown

$\begin{array}{ll}\text { Participants } & 46 \text { adults } \\ & \text { Mean age: } 35.1 \text { years (SD 7) } \\ 93 \% \text { male } & \text { Ethnicity: unknown } \\ & 100 \% \text { drug users. } 86.4 \% \text { polydrug use } \\ \text { Alcohol use: not reported } & \text { Psychiatric history: not reported } \\ \text { Eligibility criteria: inclusion: pre-incarceration heroin dependence, at least } 2 \text { months } \\ \text { sentence time remaining. Exclusion: untreated major depression or psychosis, severe } \\ \text { hepatic impairment, already in agonist maintenance treatment, pregnant }\end{array}$

Interventions

Secure establishment naltrexone intervention vs methadone treatment

(I) Received 20-pellet naltrexone implants around one month before release. Implants give sustained-release naltrexone over 5 to 6 months $(n=23)$ vs

(C) Initiated on $30 \mathrm{mg}$ methadone per day at around one month pre-release. Increased over typical period of three weeks to recommended dose of 80 to $130 \mathrm{mg}(\mathrm{n}=21)$

Outcomes

Mean days per month of criminal activity (self-reported) at 6 months

No. of days in prison (from official records of Norwegian prison) at 6 months

Mean days per month using heroin, benzodiazepines and amphetamines (self-reported)

at 6 months

Notes $\quad$ Funding was provided by the Research Council of Norway

No declarations of interest by the authors

\section{Risk of bias}

Bias

Random sequence generation (selection Low risk

bias)

\section{Support for judgement}

Treatment allocation sequence performed at an independent centre using a permuted block protocol 


\section{Lobmaier 2010 (Continued)}

\begin{tabular}{|c|c|c|}
\hline Allocation concealment (selection bias) & Low risk & $\begin{array}{l}\text { Sequentially numbered, sealed, opaque en- } \\
\text { velopes }\end{array}$ \\
\hline $\begin{array}{l}\text { Blinding of participants and personnel } \\
\text { (performance bias) } \\
\text { subjective outcomes }\end{array}$ & High risk & $\begin{array}{l}\text { p143 "the treatment conditions were not } \\
\text { blind and may have increased risk if perfor- } \\
\text { mance bias" }\end{array}$ \\
\hline $\begin{array}{l}\text { Blinding of participants and personnel } \\
\text { (performance bias) } \\
\text { objective outcomes }\end{array}$ & High risk & $\begin{array}{l}\text { p143 "the treatment conditions were not } \\
\text { blind and may have increased risk if perfor- } \\
\text { mance bias" }\end{array}$ \\
\hline $\begin{array}{l}\text { Blinding of outcome assessment (detection } \\
\text { bias) } \\
\text { subjective outcomes }\end{array}$ & Unclear risk & No information provided \\
\hline $\begin{array}{l}\text { Blinding of outcome assessment (detection } \\
\text { bias) } \\
\text { Objective outcomes }\end{array}$ & Unclear risk & No information provided \\
\hline $\begin{array}{l}\text { Incomplete outcome data (attrition bias) } \\
\text { All outcomes }\end{array}$ & Low risk & Intention-to-treat analysis conducted \\
\hline Selective reporting (reporting bias) & Unclear risk & No evidence \\
\hline Other bias & Low risk & No other concerns \\
\hline
\end{tabular}

Lobmann 2007

Methods

Allocation: random assignment

Randomisation method: block randomised

Similar on drug use: unknown

Similar on criminal activity: unknown

Blinding methodology: unknown

Loss to follow-up: adequate

Participants

1015 drug-using offenders

Age: 36 years (SD 6.7)

$\%$ male not reported

$\%$ white not reported

$100 \%$ drug users

Alcohol use not reported

Eligibility criteria: min age 23 years, ICD-10 opiate addiction, opiate addiction min 5 years, current daily heroin consumption, OTI scale health problems, not received therapy for addiction during past 6 months

Interventions

Community-based: diamorphine treatment $(\mathrm{n}=500)$ vs methadone treatment $(\mathrm{n}=515)$

Pharmacological interventions for drug-using offenders (Review) 
Lobmann 2007 (Continued)

\begin{tabular}{|c|c|c|}
\hline Outcomes & \multicolumn{2}{|c|}{$\begin{array}{l}12 \text { months follow up and outcomes. } \\
\text { Drug use and criminal activity (self-report and official records) }\end{array}$} \\
\hline Notes & \multicolumn{2}{|c|}{ Article in German, single reviewer translation completed } \\
\hline \multicolumn{3}{|l|}{ Risk of bias } \\
\hline Bias & Authors' judgement & Support for judgement \\
\hline $\begin{array}{l}\text { Random sequence generation (selection } \\
\text { bias) }\end{array}$ & Low risk & Block randomisation used \\
\hline Allocation concealment (selection bias) & Unclear risk & No information provided \\
\hline $\begin{array}{l}\text { Blinding of participants and personnel } \\
\text { (performance bias) } \\
\text { subjective outcomes }\end{array}$ & Unclear risk & No information provided \\
\hline $\begin{array}{l}\text { Blinding of participants and personnel } \\
\text { (performance bias) } \\
\text { objective outcomes }\end{array}$ & Unclear risk & No information provided \\
\hline $\begin{array}{l}\text { Blinding of outcome assessment (detection } \\
\text { bias) } \\
\text { subjective outcomes }\end{array}$ & Unclear risk & No information provided \\
\hline $\begin{array}{l}\text { Blinding of outcome assessment (detection } \\
\text { bias) } \\
\text { Objective outcomes }\end{array}$ & Unclear risk & No information provided \\
\hline $\begin{array}{l}\text { Incomplete outcome data (attrition bias) } \\
\text { All outcomes }\end{array}$ & Low risk & $\begin{array}{l}\text { Data on all outcomes presented, limited at- } \\
\text { trition noted }\end{array}$ \\
\hline Selective reporting (reporting bias) & Unclear risk & No information provided \\
\hline Other bias & Unclear risk & No information provided \\
\hline
\end{tabular}


Methods

\begin{tabular}{ll} 
and subsequently periodically based on $7: 3$ \\
Randomisation method: inadequate, personnel aware of allocation \\
Similar on drug use: yes \\
Similar on criminal activity: yes \\
Blinding methodology: unknown \\
Loss to follow-up: inadequate, up to $30 \%$ lost \\
\hline Participants & 133 male inmates \\
& Age: group (a) 38.4 years (SD 7.9$)$, (b) 40.7 years $(9.1)$ \\
& $100 \%$ male \\
& $25 \%$ black, $64 \%$ Hispanic \\
& $100 \%$ drug users \\
Alcohol use: not reported & Eligibility criteria: inmates who were eligible for the Key Extended Entry Program \\
(KEEP), 18 to 65 years old, sentenced to 10 to 90 days jail time, and expected to reside \\
locally post-release
\end{tabular}

Prison/secure establishment based methadone $(n=56)$ vs buprenorphine $(n=77)$

(C) Methadone: Participants were given liquid methadone dispensed once daily usual maintenance dose was $30 \mathrm{mg}$ which could be stepped up to a maximum of $70 \mathrm{mg}$ if clinically indicated and participant agreed

(I) Buprenorphine: The sublingual combination burprenorphine/naloxone tablet was used for both induction and maintenance, initial dose of $4 \mathrm{mg}$ which could be stepped up to $8 \mathrm{mg}$ on the first day and could be stepped up to $32 \mathrm{mg}$ on subsequent days. Participants observed until the tablet had dissolved

Arrest (self-report) during the past 12 months at 3-month follow-up for property crime, drug posession and \% reincarcerated. Drug use past 30 days (self-report), mean number of days heroin use post-release at 3-month follow-up

No funding information provided by the authors

No declarations of interest reported by the authors

\section{Risk of bias}

\begin{tabular}{l|l|l}
\hline Bias & Authors' judgement & Support for judgement \\
\hline $\begin{array}{l}\text { Random sequence generation (selection } \\
\text { bias) }\end{array}$ & Low risk & $\begin{array}{l}\text { Random number generator used. Alloca- } \\
\text { tion was originally } 1: 1, \text { but loss in one } \\
\text { group meant that treatment-adaptive ran- } \\
\text { domisation was used at a ratio of } 7: 3\end{array}$ \\
\hline Allocation concealment (selection bias) & High risk & Project director was naive to allocation, but \\
research assistant was not
\end{tabular}

Blinding of participants and personnel Unclear risk (performance bias)

No information provided 


\section{Magura 2009 (Continued)}

\begin{tabular}{l|l|l|l|l}
\hline $\begin{array}{l}\text { Blinding of participants and personnel } \\
\text { (performance bias) } \\
\text { objective outcomes }\end{array}$ & No information provided \\
\hline
\end{tabular}

Blinding of outcome assessment (detection Unclear risk No information provided

bias)

subjective outcomes

Blinding of outcome assessment (detection Unclear risk

bias)

Objective outcomes

Incomplete outcome data (attrition bias) Unclear risk

All outcomes

Some attrition occurred before medication was received by buprenorphine-assigned participants. $30 \%$ of participants could not be interviewed at follow-up

\begin{tabular}{|c|c|c|}
\hline Selective reporting (reporting bias) & Unclear risk & No information reported \\
\hline Other bias & High risk & $\begin{array}{l}\text { Participants at one site received methadone } \\
\text { suboptimal doses }(30 \mathrm{mg}) \text {. The study con- } \\
\text { tained a modest sample size }\end{array}$ \\
\hline
\end{tabular}

\section{Wright 2011}

Methods

Allocation: random allocation

Randomisation method: low risk, generated using Microsoft Excel

Similar on drug use: yes

Similar on criminal activity: not reported

Blinding methodology: high risk, open-label

Loss to follow-up: high risk

Participants

439 eligible adults of whom 133 declined leaving 306 available for randomisation. Seventeen excluded at randomisation

289 adults randomised and allocated

The median age was 30.8 years (interquartile range (IQR), 26.9 to 34.9)

$\%$ male, not reported - mixed sample ( 1 all-female and 2 all-male prisons)

Methadone, $89.9 \%$ white; buprenorphine, $93.6 \%$ white

$\%$ drug users not reported

$\%$ alcohol, not reported

$\%$ Psychiatric history, not reported

Eligibility criteria: Inclusion criteria: 21 to 65 years old; using illicit opiates as confirmed by urine test; expressing a wish to detoxify and remain abstinent; willing to give informed consent; and remaining in custody for at least 28 days. Exclusion criteria: contraindications to methadone or buprenorphine; medical conditions requiring emergency admission to hospital, thus precluding detoxification; currently undergoing detoxification 
from other addictive drugs whereby concurrent opiate detoxification would not be clinically indicated; and previously randomised into the trial

Sublingual buprenorphine $(\mathrm{n}=141)$ vs Oral methadone $(\mathrm{n}=148)$
(I) Sublingual buprenorphine: prescribed daily within set dose limits of $8 \mathrm{mg}$ for days 1
to $5,6 \mathrm{mg}$ for days 6 to $7,4 \mathrm{mg}$ for days 8 to 10 and subsequently descreasing to a limit
of 0.4 on day 20
(C) Oral methadone $(1 \mathrm{mg} / 1 \mathrm{ml}$ mixture): prescribed daily within set dose limits of 30
mg for days 1 to $5,25 \mathrm{mg}$ for days 6 to $7,22 \mathrm{mg}$ for days 8 to $9,20 \mathrm{mg}$ for days 10 to
11 and subsequently descreasing to a limit of $2 \mathrm{mg}$ on day 20

Outcomes

The primary outcome was abstinence from illicit opiates at 8 days post detoxification, as indicated by a urine test

Secondary outcomes included abstinence status at 1,3, and 6 months post detoxification, ascertained via urine test if the participant was still in prison. If the participant had been released, local community drugs service records were accessed to verify abstinence. Adverse events were recorded and a researcher was informed immediately of any serious adverse events, which were then reported to the regulatory authorities. These included overdose, self-harm, or suicide attempt; inappropriate use of prescribed medication; or admission as a prison healthcare inpatient

Notes

Funded by Department of Health, National Research and Development Programme on Forensic Mental Health Research Funding Scheme 2004

The authors state that they have no competing interests.

\section{Risk of bias}

\begin{tabular}{lll}
\hline Bias & Authors' judgement & Support for judgement \\
\hline $\begin{array}{l}\text { Random sequence generation (selection } \\
\text { bias) }\end{array}$ & Low risk & $\begin{array}{l}\text { Randomisation sequence (with random } \\
\text { block size) was generated using Microsoft } \\
\text { Excel RAND function }\end{array}$ \\
\hline
\end{tabular}

Allocation concealment (selection bias) Low risk

Blinding of participants and personnel High risk (performance bias)

subjective outcomes

Blinding of participants and personnel High risk (performance bias)

objective outcomes
Sealed, opaque, consecutively numbered envelopes concealing the name of the allocated intervention were prepared by a researcher who had no contact with participants

Open label "The prescribing doctor randomised by opening the next envelope and prescribing the intervention named inside. Both prisoner and doctor were blind to the intervention until this point."

Open label "The prescribing doctor randomised by opening the next envelope and prescribing the intervention named inside. Both prisoner and doctor were blind to the 
Wright 2011 (Continued)

intervention until this point."

\begin{tabular}{|c|c|c|}
\hline $\begin{array}{l}\text { Blinding of outcome assessment (detection } \\
\text { bias) } \\
\text { subjective outcomes }\end{array}$ & Unclear risk & $\begin{array}{l}\text { No statement regarding blinding of in- } \\
\text { dividual who undertook the biochemical } \\
\text { urine tests }\end{array}$ \\
\hline $\begin{array}{l}\text { Blinding of outcome assessment (detection } \\
\text { bias) } \\
\text { Objective outcomes }\end{array}$ & Unclear risk & $\begin{array}{l}\text { No statement regarding blinding of indi- } \\
\text { vidual who recorded self-report or clinical } \\
\text { notes }\end{array}$ \\
\hline $\begin{array}{l}\text { Incomplete outcome data (attrition bias) } \\
\text { All outcomes }\end{array}$ & High risk & $\begin{array}{l}\text { High levels of attrition. } 50 \% \text { buprenor- } \\
\text { phine and } 45 \% \text { methadone did not provide } \\
\text { urine sample at day } 8,65 \% \text { and } 62 \% \text { at } \\
1 \text { month, } 80 \% \text { and } 85 \% \text { at } 3 \text { months and } \\
86 \% \text { and } 91 \% \text { at } 6 \text { months. ITT under- } \\
\text { taken assuming if no objective or subjective } \\
\text { data available, participants were not absti- } \\
\text { nent }\end{array}$ \\
\hline Selective reporting (reporting bias) & High risk & $\begin{array}{l}\text { Adverse events and reasons for withdrawal } \\
\text { stated as being recorded but no outcome } \\
\text { data reported }\end{array}$ \\
\hline Other bias & Low risk & No other concerns \\
\hline
\end{tabular}

Characteristics of excluded studies [ordered by study ID]

\begin{tabular}{ll}
\hline Study & Reason for exclusion \\
\hline Alemi 2010 & Does not concern pharmacological intervention \\
\hline Alessi 2011 & Not original RCT. Data is from previous, older studies. \\
\hline Andersson 2014 & Intervention not aimed at reducing drug use or criminal activity, or both \\
\hline Anglin 1999 & $\begin{array}{l}\text { The study did not report relevant drug or crime outcome measures, or both, at both the pre- and post- } \\
\text { intervention periods }\end{array}$ \\
\hline Awgu 2010 & $\begin{array}{l}\text { The study did not report relevant drug or crime outcome measures, or both, at both the pre- and post- } \\
\text { intervention periods }\end{array}$ \\
\hline Azbel 2013 & Intervention not aimed at reducing drug use or criminal activity, or both \\
\hline Baldus 2011 & Study protocol only, author has since died.
\end{tabular}

Pharmacological interventions for drug-using offenders (Review) 
(Continued)

\begin{tabular}{|c|c|}
\hline Baltieri 2014 & Intervention not aimed at reducing drug use or criminal activity, or both \\
\hline Barnes 2012 & Not using a population of drug-using offenders \\
\hline Berman 2004 & The intervention was not aimed at reducing drug use or criminal activity or both in drug-using offenders \\
\hline Black 2011 & Not offender population \\
\hline Brady 2010 & Not RCT \\
\hline Braithwaite 2005 & $\begin{array}{l}\text { The study did not report relevant drug or crime outcome measures, or both, at both the pre- and post- } \\
\text { intervention periods }\end{array}$ \\
\hline Breckenridge 2000 & Evaluated a DWI Court for alcoholic offenders, not illicit drug use, not a pharmacological intervention \\
\hline Britt 1992 a-d & Does not concern pharmacological intervention. \\
\hline Brown 2001 & $\begin{array}{l}3 \text {-arm study in which only } 2 \text { arms were randomised - } 1 \text { treatment arm and control arm. Results presented as } \\
\text { both treatment arms combined vs control }\end{array}$ \\
\hline Burdon 2013 & Not a trial. \\
\hline Carr 2008 & $\begin{array}{l}\text { The population of the study was not } 100 \% \text { drug-using offenders that were specifically referred by the criminal } \\
\text { justice system to the intervention }\end{array}$ \\
\hline Carroll 2006 & Does not concern pharmacological intervention \\
\hline Carroll 2011 & Not offender population \\
\hline Carroll 2012 & Not a pharmacological intervention. \\
\hline Chandler 2006 & $\begin{array}{l}\text { The study did not report relevant drug or crime outcome measures, or both, at both the pre- and post- } \\
\text { intervention periods }\end{array}$ \\
\hline Chaple 2014 & No pre- and post-test measures of drug or crime, or both. \\
\hline Clair 2013 & No data presented at pre- and post-test outcomes for crime and drug \\
\hline Cogswell 2011 & Population not offenders. \\
\hline Cosden 2003 & Does not concern pharmacological intervention \\
\hline Cosden 2005 & $\begin{array}{l}\text { The study did not report relevant drug or crime outcome measures, or both, at both the pre- and post- } \\
\text { intervention periods }\end{array}$ \\
\hline Coviello 2012 & Not a Randomised Controlled Trial \\
\hline
\end{tabular}


(Continued)

\begin{tabular}{|c|c|}
\hline Cox 2013 & Not an offender population \\
\hline Cropsey 2013 & Not a Randomised Controlled Trial \\
\hline Cullen 2011 & Not a drug program aimed at reducing drug use/criminal activity in drug using offenders \\
\hline Cusack 2010 & Not a drug program aimed at reducing drug use/criminal activity in drug using offenders \\
\hline D’Amico 2013 & Does not present data for pre- and post-test information on drug or crime measures, or both \\
\hline Dakof 2010 & Study population is mothers of offenders, not offenders themselves \\
\hline Dana 2013 & Not an RCT \\
\hline DeFulio 2013 & Not an RCT \\
\hline Dembo 2000 & $\begin{array}{l}\text { The study did not report relevant drug or crime outcome measures, or both, at both the pre- and post- } \\
\text { intervention periods. } \\
\text { The follow-up periods reported for the different groups were not equivalent }\end{array}$ \\
\hline Deschenes 1994 & Does not concern pharmacological intervention \\
\hline Di Nitto 2002 & The follow-up periods reported for the different groups were not equivalent \\
\hline Diamond 2006 & $\begin{array}{l}\text { The study did not report relevant drug or crime outcome measures, or both, at both the pre- and post- } \\
\text { intervention periods }\end{array}$ \\
\hline Dugan 1998 & $\begin{array}{l}\text { The study did not report relevant drug or crime outcome measures, or both, at both the pre- and post- } \\
\text { intervention periods }\end{array}$ \\
\hline Evans 2012 & Not an RCT \\
\hline Forsberg 2011 & Does not concern pharmacological intervention \\
\hline Freudenberg 2010 & Does not concern pharmacological intervention \\
\hline Friedman 2012 & Not an RCT \\
\hline Frost 2013 & Not an RCT \\
\hline Gagnon 2010 & Not offender population \\
\hline
\end{tabular}

Gil 2004 The study did not report relevant drug or crime outcome measures, or both, at both the pre- and postintervention periods

Gordon $2012 \quad$ No relevant data; all analysis at baseline; no pre- and post-test information on drug use or criminal activity, or both 
(Continued)

\begin{tabular}{|c|c|}
\hline Gordon 2013 & No relevant data; all analysis secondary, not a primary RCT. \\
\hline Gottfredson 2002 & Does not concern pharmacological intervention \\
\hline Grohman 2002 & $\begin{array}{l}\text { The study did not report relevant drug or crime outcome measures, or both, at both the pre- and post- } \\
\text { intervention periods }\end{array}$ \\
\hline Grommon 2013a & Not a pharmacological intervention. \\
\hline Grommon $2013 b$ & Not a pharmacological intervention. \\
\hline Guydish 2011 & Does not concern pharmacological intervention \\
\hline Guydish 2014 & Not criminal justice population \\
\hline Haapanen 2002 & Does not concern pharmacological intervention \\
\hline Haasen 2010 & Not offender population \\
\hline Hanlon 1999 & Does not concern pharmacological intervention \\
\hline Harada 2012 & No data on pre- and post-test outcomes for drug or criminal justice, or both \\
\hline Harrell 2001 & $\begin{array}{l}\text { The study did not report relevant drug or crime outcome measures, or both, at both the pre- and post- } \\
\text { intervention periods }\end{array}$ \\
\hline Henderson 2010 & $\begin{array}{l}\text { The study did not report relevant drug or crime outcome measures, or both, at both the pre- and post- } \\
\text { intervention periods }\end{array}$ \\
\hline Henggeler 1991 & $\begin{array}{l}\text { The study did not report relevant drug or crime outcome measures, or both, at both the pre- and post- } \\
\text { intervention periods }\end{array}$ \\
\hline Henggeler 1999 & Does not concern pharmacological intervention \\
\hline Henggeler 2002 & $\begin{array}{l}\text { The study did not report relevant drug or crime outcome measures, or both, at both the pre- and post- } \\
\text { intervention periods }\end{array}$ \\
\hline Henggeler 2006 & Does not concern pharmacological intervention \\
\hline Henggeler 2012 & Not a pharmacological intervention. \\
\hline Hser 2011 & Unclear if study looks at offender population \\
\hline Hser 2013 & Not a pharmacological intervention \\
\hline
\end{tabular}

Inciardi 2004 Some participants were not randomly selected into the treatment groups 
(Continued)

\begin{tabular}{|c|c|}
\hline Jain 2011 & Paper not available and not clear from abstract if looks at offender population \\
\hline Johnson 2011 & Does not concern pharmacological intervention \\
\hline Johnson 2012 & Does not concern pharmacological intervention \\
\hline Jones 2013 & Not a pharmacological intervention \\
\hline Jones, 2011 & Evaluated a DWI Court for alcoholic offenders, not illicit drug use \\
\hline Katz 2007 & $\begin{array}{l}\text { The population of the study was not } 100 \% \text { drug-using offenders that were specifically referred by the criminal } \\
\text { justice system to the intervention }\end{array}$ \\
\hline Kelly 2013 & Not a pharmacological intervention. \\
\hline Kidorf 2013 & Not offender population \\
\hline King 2014 & Not offender population \\
\hline Kinlock 2008 & Not a pharmacological intervention. \\
\hline Kinlock 2009a & Conference proceedings only \\
\hline Kinlock 2009b & Not a pharmacological intervention \\
\hline Kok 2013 & Not offender population \\
\hline
\end{tabular}

Law 2012 The study did not report relevant drug or crime outcome measures, or both, at both the pre- and postintervention periods

Lee $2012 \quad$ No pre- and post-test data for outcomes of drug or criminal justice measures, or both

Liddle 2011 The study did not report relevant drug or crime outcome measures, or both, at both the pre- and postintervention periods

Ling $2013 \quad$ Not offender population

Lobmann $2009 \quad$ No pre- and post-outcome measures for drug or crime outcomes, or both

MacDonald $2007 \quad$ Evaluated a DWI Court for alcoholic offenders, not illicit drug use

Marlowe 2003 The study did not report relevant drug or crime outcome measures, or both, at both the pre- and postintervention periods

Marlowe $2005 \quad$ Not a pharmacological intervention 
(Continued)

\begin{tabular}{|c|c|}
\hline Marlowe 2007 & $\begin{array}{l}\text { Participants randomised to receive treatment were not randomised into the different treatment groups but } \\
\text { were identified by level of risk. Not an RCT }\end{array}$ \\
\hline Marlowe 2008 & Does not concern pharmacological intervention \\
\hline Marsch 2014 & Not offender population \\
\hline Martin 1993 & Does not concern pharmacological intervention \\
\hline Mbilinyi 2011 & Participants not recruited through criminal justice system \\
\hline McKendrick 2007 & $\begin{array}{l}\text { The study did not report relevant drug or crime outcome measures, or both, at both the pre- and post- } \\
\text { intervention periods }\end{array}$ \\
\hline McKenzie 2012 & Does not concern pharmacological intervention \\
\hline Messina 2000 & $\begin{array}{l}\text { The population of the study was not } 100 \% \text { drug-using offenders that were specifically referred by the criminal } \\
\text { justice system to the intervention. } \\
\text { The study did not report relevant drug or crime outcome measures, or both, at both the pre- and post- } \\
\text { intervention periods }\end{array}$ \\
\hline Messina 2010 & No pharmacological interventions \\
\hline Milloy 2011 & No pre- and post-data for outcomes of crime or drug use, or both \\
\hline Needels 2005 & $\begin{array}{l}\text { The population of the study was not } 100 \% \text { drug-using offenders that were specifically referred by the criminal } \\
\text { justice system to the intervention }\end{array}$ \\
\hline Nemes 1998 & $\begin{array}{l}\text { The population of the study was not } 100 \% \text { drug-using offenders that were specifically referred by the criminal } \\
\text { justice system to the intervention. } \\
\text { The study did not report relevant drug or crime outcome measures, or both, at both the pre- and post- } \\
\text { intervention periods }\end{array}$ \\
\hline Nemes 1999 & $\begin{array}{l}\text { The population of the study was not } 100 \% \text { drug-using offenders that were specifically referred by the criminal } \\
\text { justice system to the intervention. } \\
\text { The study did not report relevant drug or crime outcome measures, or both, at both the pre- and post- } \\
\text { intervention periods }\end{array}$ \\
\hline Nielsen 1996 & Does not concern pharmacological intervention \\
\hline Nosyk 2010 & Not offender population \\
\hline Petersilia 1992 & Does not concern pharmacological intervention \\
\hline Petry 2005 & Not $100 \%$ criminal justice population. \\
\hline Petry 2011 & Not offender population \\
\hline
\end{tabular}

Pharmacological interventions for drug-using offenders (Review)

Copyright () 2015 The Cochrane Collaboration. Published by John Wiley \& Sons, Ltd. 
(Continued)

\begin{tabular}{|c|c|}
\hline Polsky 2010 & Not offender population \\
\hline Prendergast 2003 & Does not concern pharmacological intervention \\
\hline Prendergast 2008 & Does not concern pharmacological intervention \\
\hline Prendergast 2009 & $\begin{array}{l}\text { The study did not report relevant drug or crime outcome (or both) measures at both the pre- and post- } \\
\text { intervention periods }\end{array}$ \\
\hline Prendergast 2011 & Does not concern pharmacological intervention \\
\hline Proctor 2012 & No pharmacological interventions \\
\hline Reimer 2011 & Not offender population \\
\hline Robertson 2006 & $\begin{array}{l}\text { The population of the study was not } 100 \% \text { drug-using offenders that were specifically referred by the criminal } \\
\text { justice system to the intervention }\end{array}$ \\
\hline Rosengard 2008 & $\begin{array}{l}\text { The study did not report relevant drug or crime outcome (or both) measures at both the pre- and post- } \\
\text { intervention periods }\end{array}$ \\
\hline Rossman 1999 & Does not concern pharmacological intervention \\
\hline Rounsaville 2001 & No pre- and post-test data presented on drug use or crime outcomes, or both \\
\hline Rowan-Szal 2005 & Population not offenders. \\
\hline Rowan-Szal 2009 & Not RCT \\
\hline Rowe 2007 & $\begin{array}{l}\text { The population of the study was not } 100 \% \text { drug-using offenders that were specifically referred by the criminal } \\
\text { justice system to the intervention }\end{array}$ \\
\hline Sacks 2004 & Does not concern pharmacological intervention \\
\hline Sacks 2008 & Does not concern pharmacological intervention \\
\hline Sacks 2011 & Does not concern pharmacological intervention \\
\hline Sanchez-Hervas 2010 & Population not offenders. \\
\hline Schaeffer 2014 & Does not contain a pharmacological intervention \\
\hline Schmiege 2009 & No data for pre- and post-test outcome measures of drug or crime outcomes, or both \\
\hline Schwartz 2006 & Not offender population \\
\hline Shanahan 2004 & This is not a pharmacological intervention \\
\hline
\end{tabular}


(Continued)

\begin{tabular}{|c|c|}
\hline Sheard 2009 & $\begin{array}{l}\text { The study did not report relevant drug or crime outcome (or both) measures at both the pre- and post- } \\
\text { intervention periods }\end{array}$ \\
\hline Siegal 1999 & Not RCT \\
\hline Sinha 2003 & Not a pharmacological intervention. \\
\hline Smith 2010 & Does not concern pharmacological intervention \\
\hline Solomon 1995 & Not an offender population. \\
\hline Specka 2013 & Not an offender population. \\
\hline Stanger 2009 & $\begin{array}{l}\text { The population of the study was not } 100 \% \text { drug-using offenders that were specifically referred by the criminal } \\
\text { justice system to the intervention }\end{array}$ \\
\hline Staton-Tindall 2009 & No control group; not an RCT. \\
\hline Stein 2006 & No pre- and post-test data for drug or crime outcome measures, or both \\
\hline Stein 2010 & Not offender population \\
\hline Stein 2011 & Does not concern pharmacological intervention \\
\hline Stevens 1998 & $\begin{array}{l}\text { The population of the study was not } 100 \% \text { drug-using offenders that were specifically referred by the criminal } \\
\text { justice system to the intervention }\end{array}$ \\
\hline Svikis 2011 & Not clear if offender population \\
\hline Taxman 2006 & Does not concern pharmacological intervention \\
\hline Vagenas 2014 & No pre- and post-test data on drug or crime outcome measures, or both \\
\hline Vanderberg 2002 & No pre- and post-test outcome data on crime or drug measures, or both \\
\hline Villagrá Lanza 2013 & Does not concern pharmacological intervention \\
\hline Walters 2014 & No data on pre- and post-test information for drug or crime outcome measures, or both \\
\hline Wang 2010 & Participants not in criminal justice system \\
\hline Webster 2014 & No data on pre- and post-test information for drug or crime outcome measures, or both \\
\hline White 2006 & $\begin{array}{l}\text { Randomisation broken as } 40 \% \text { of control arm were allowed to receive treatment (acupuncture) outside of } \\
\text { the intervention }\end{array}$ \\
\hline Williams 2011 & Not RCT \\
\hline
\end{tabular}


(Continued)

\begin{tabular}{ll}
\hline Winstanley 2011 & Not clear if offender population \\
\hline Witkiewitz 2010 & Not clear if offender population \\
\hline Wolff 2012 & No data for pre- and post-test outcomes of drug or crime measures, or both \\
\hline Zlotnick 2009 & Does not concern pharmacological intervention \\
\hline
\end{tabular}

Characteristics of ongoing studies [ordered by study ID]

\section{Springer 2015}

\begin{tabular}{|c|c|}
\hline Trial name or title & $\begin{array}{l}\text { Naltrexone for opioid dependent released HIV+ criminal justice populations } \\
\text { Referred to as NEWHOPE. }\end{array}$ \\
\hline Methods & $\begin{array}{l}\text { Our specific aim is to conduct a placebo-controlled RCT of depot NTX (d-NTX) for HIV+ prisoners with } \\
\text { OD who are transitioning to the community } \\
150 \text { subjects within CJS in New Haven, Hartford and Springfield. Subjects will be randomized 2:1 to d-NTX } \\
\text { or d-placebo for } 6 \text { months and observed for } 12 \text { months }\end{array}$ \\
\hline Participants & $\begin{array}{l}\text { HIV-infected prisoners with opioid dependence who are treated with depot naltrexone as they are transitioning } \\
\text { from the correctional to the community setting } \\
150 \text { participants. }\end{array}$ \\
\hline Interventions & Depot naltrexone versus placebo \\
\hline Outcomes & $\begin{array}{l}6 \text { and } 12 \text { months } \\
\text { HIV treatment (HIV-1 RNA levels, CD4 count, ART adherence, retention in care), substance abuse (time } \\
\text { to relapse to opioid use, \% opioid negative urines, opioid craving), adverse side effects and HIV risk behavior } \\
\text { (sexual and drug-related risks) } \\
\text { The public health relevance is that outcomes from this study will establish the efficacy, safety and tolerability of } \\
\text { pharmacological therapy using naltrexone treatment among HIV }+s \text { and establish depot-naltrexone treatment } \\
\text { as an effective, evidence-based treatment for opioid dependence for released HIV+ prisoners }\end{array}$ \\
\hline Starting date & 2012 \\
\hline Contact information & Yale University \\
\hline Notes & \\
\hline
\end{tabular}


DATA AND ANALYSES

Comparison 1. Agonist pharmacological vs no intervention

\begin{tabular}{|c|c|c|c|c|}
\hline Outcome or subgroup title & $\begin{array}{l}\text { No. of } \\
\text { studies }\end{array}$ & $\begin{array}{c}\text { No. of } \\
\text { participants }\end{array}$ & Statistical method & Effect size \\
\hline 1 Drug use (objective) & 2 & 237 & Risk Ratio (M-H, Random, 95\% CI) & $0.72[0.51,1.00]$ \\
\hline $\begin{array}{l}2 \text { Drug use self reported } \\
\text { dichotomous }\end{array}$ & 3 & 317 & Risk Ratio (M-H, Random, 95\% CI) & $0.61[0.31,1.18]$ \\
\hline $\begin{array}{l}3 \text { Drug use self reported } \\
\text { continuous }\end{array}$ & 3 & 510 & Std. Mean Difference (IV, Fixed, 95\% CI) & $-0.62[-0.85,-0.39]$ \\
\hline 4 Criminal activity dichotomous & 3 & & Risk Ratio (M-H, Random, 95\% CI) & Subtotals only \\
\hline 4.1 Arrests & 1 & 62 & Risk Ratio (M-H, Random, 95\% CI) & $0.60[0.32,1.14]$ \\
\hline 4.2 Re-incarceration & 3 & 472 & Risk Ratio (M-H, Random, 95\% CI) & $0.77[0.36,1.64]$ \\
\hline 5 Criminal activity continuous & 1 & 51 & Mean Difference (IV, Fixed, 95\% CI) & $\begin{array}{l}-74.21[-133.53,- \\
14.89]\end{array}$ \\
\hline
\end{tabular}

Comparison 2. Antagonist (Naltrexone) vs no pharmacological

\begin{tabular}{lccll} 
Outcome or subgroup title & $\begin{array}{c}\text { No. of } \\
\text { studies }\end{array}$ & $\begin{array}{c}\text { No. of } \\
\text { participants }\end{array}$ & Statistical method & Effect size \\
\hline 1 Criminal activity dichotomous & 2 & & Risk Ratio (M-H, Random, 95\% CI) & Subtotals only \\
1.1 Reincarceration & 2 & 114 & Risk Ratio (M-H, Random, 95\% CI) & $0.40[0.21,0.74]$ \\
2 drug use (objective) & 1 & 63 & Risk Ratio (M-H, Fixed, 95\% CI) & $0.69[0.28,1.70]$ \\
\hline
\end{tabular}

Comparison 3. Methadone vs buprenorphine

\begin{tabular}{lcccc} 
Outcome or subgroup title & $\begin{array}{c}\text { No. of } \\
\text { studies }\end{array}$ & $\begin{array}{c}\text { No. of } \\
\text { participants }\end{array}$ & Statistical method & Effect size \\
\hline $\begin{array}{l}1 \text { Self reported drug use } \\
\text { dichotomous }\end{array}$ & 2 & 370 & Risk Ratio (M-H, Random, 95\% CI) & $1.04[0.69,1.55]$ \\
$\begin{array}{l}\text { Self reported drug use } \\
\text { continuous }\end{array}$ & 1 & 81 & Mean Difference (IV, Fixed, 95\% CI) & $0.70[-5.33,6.73]$ \\
$\begin{array}{l}\text { 3 Criminal activity dichotomous } \\
\text { 3.1 re incarceration }\end{array}$ & 1 & & Risk Ratio (M-H, Fixed, 95\% CI) & $\begin{array}{c}\text { Subtotals only } \\
\text { Risk Ratio (M-H, Fixed, 95\% CI) }\end{array}$ \\
\hline
\end{tabular}

Pharmacological interventions for drug-using offenders (Review) 


\begin{tabular}{lcccc} 
Outcome or subgroup title & $\begin{array}{c}\text { No. of } \\
\text { studies }\end{array}$ & $\begin{array}{c}\text { No. of } \\
\text { participants }\end{array}$ & Statistical method & Effect size \\
\hline $\begin{array}{l}1 \text { criminal activity dichotomous } \\
1.1 \text { arrest }\end{array}$ & 1 & & Risk Ratio (M-H, Fixed, 95\% CI) & Subtotals only \\
& 1 & 825 & Risk Ratio (M-H, Fixed, 95\% CI) & $1.25[1.03,1.51]$ \\
\hline
\end{tabular}

Comparison 5. Methadone vs naltrexone

\begin{tabular}{lcclll} 
Outcome or subgroup title & $\begin{array}{c}\text { No. of } \\
\text { studies }\end{array}$ & $\begin{array}{c}\text { No. of } \\
\text { participants }\end{array}$ & \multicolumn{1}{c}{ Statistical method } & Effect size \\
\hline 1 self reported drug use continuous & 1 & 44 & Mean Difference (IV, Fixed, 95\% CI) & $4.60[-3.54,12.74]$ \\
2 criminal activity dichotomous & 1 & & Risk Ratio (M-H, Fixed, 95\% CI) & Subtotals only \\
$\quad \begin{array}{l}2.1 \text { re incarceration } \\
3 \text { criminal activity continuous }\end{array}$ & 1 & 44 & Risk Ratio (M-H, Fixed, 95\% CI) & $1.10[0.37,3.26]$ \\
\hline
\end{tabular}

\footnotetext{
Analysis I.I. Comparison I Agonist pharmacological vs no intervention, Outcome I Drug use (objective).

Review: Pharmacological interventions for drug-using offenders

Comparison: I Agonist pharmacological vs no intervention

Outcome: I Drug use (objective)

Study or subgroup Nharmacological No pharmacological Risk Ratio Neight $\quad$ Re

\begin{tabular}{|c|c|c|c|c|c|}
\hline & $\mathrm{n} / \mathrm{N}$ & $\mathrm{n} / \mathrm{N}$ & $\begin{array}{c}\text { M- } \\
\text { H,Random, } 95 \% \\
\mathrm{Cl}\end{array}$ & & $\begin{array}{c}\mathrm{M}- \\
\mathrm{H}, \mathrm{R} \text { andom,95\% } \\
\mathrm{Cl}\end{array}$ \\
\hline Cropsey 2011 & $8 / 24$ & $7 / 12$ & $\rightarrow$ & $20.1 \%$ & $0.57[0.27,1.20]$ \\
\hline Dolan 2003 & $33 / 106$ & $39 / 95$ & & $79.9 \%$ & $0.76[0.52,1.10]$ \\
\hline
\end{tabular}

$\begin{array}{lll}\text { Total }(95 \% \text { CI }) & 130 & 107\end{array}$

Total events: 4I (Pharmacological), 46 (No pharmacological)

Heterogeneity: $\mathrm{Tau}^{2}=0.0 ; \mathrm{Chi}^{2}=0.45, \mathrm{df}=\mathrm{I}(\mathrm{P}=0.50) ; \mathrm{I}^{2}=0.0 \%$

Test for overall effect: $Z=1.97(P=0.049)$

Test for subgroup differences: Not applicable

$100.0 \%$

$0.72[0.51,1.00]$
} 
Analysis I.2. Comparison I Agonist pharmacological vs no intervention, Outcome 2 Drug use self reported dichotomous.

Review: Pharmacological interventions for drug-using offenders

Comparison: I Agonist pharmacological vs no intervention

Outcome: 2 Drug use self reported dichotomous

\begin{tabular}{|c|c|c|c|c|c|}
\hline Study or subgroup & $\begin{array}{r}\text { Pharmacological } \\
\mathrm{n} / \mathrm{N}\end{array}$ & No pharmacological & $\begin{array}{c}\text { Risk Ratio } \\
\text { M- } \\
\text { H,Random,95\% } \\
\mathrm{Cl} \\
\end{array}$ & Weight & $\begin{array}{c}\text { Risk Ratio } \\
\text { M- } \\
\text { H,Random,95\% } \\
\text { Cl } \\
\end{array}$ \\
\hline Cropsey 2011 & $7 / 24$ & $6 / 12$ & $\rightarrow$ & $24.4 \%$ & $0.58[0.25,1.35]$ \\
\hline Dolan 2003 & $41 / 129$ & $92 / 124$ & घ & $37.9 \%$ & $0.43[0.33,0.56]$ \\
\hline Dole 1969 & $10 / 12$ & $15 / 16$ & E & $37.7 \%$ & $0.89[0.67,1.18]$ \\
\hline Total $(95 \%$ CI $)$ & 165 & 152 & $<$ & $100.0 \%$ & $0.61[0.31,1.18]$ \\
\hline \multicolumn{6}{|c|}{ Total events: 58 (Pharmacological), 113 (No pharmacological) } \\
\hline \multicolumn{6}{|c|}{ Heterogeneity: $\mathrm{Tau}^{2}=0.28 ; \mathrm{Chi}^{2}=18.04, \mathrm{df}=2(P=0.000 \mathrm{I} 2) ;\left.\right|^{2}=89 \%$} \\
\hline \multicolumn{6}{|c|}{ Test for overall effect: $Z=1.48(P=0.14)$} \\
\hline \multicolumn{6}{|c|}{ Test for subgroup differences: Not applicable } \\
\hline & & & 10 & 100 & \\
\hline
\end{tabular}


Analysis I.3. Comparison I Agonist pharmacological vs no intervention, Outcome 3 Drug use self reported continuous.

Review: Pharmacological interventions for drug-using offenders

Comparison: I Agonist pharmacological vs no intervention

Outcome: 3 Drug use self reported continuous

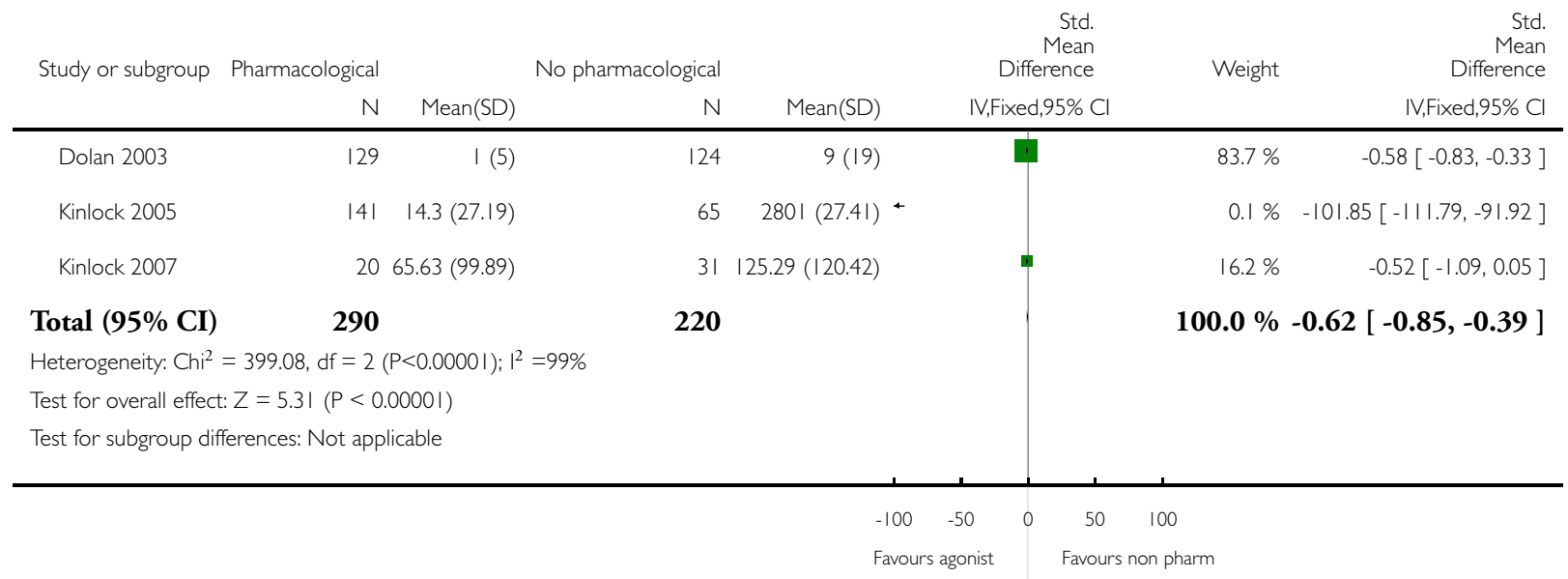


Analysis I.4. Comparison I Agonist pharmacological vs no intervention, Outcome 4 Criminal activity dichotomous.

Review: Pharmacological interventions for drug-using offenders

Comparison: I Agonist pharmacological vs no intervention

Outcome: 4 Criminal activity dichotomous

\begin{tabular}{|c|c|c|c|c|c|c|}
\hline Study or subgroup & Pharmacological & No pharmacological & & $\begin{array}{c}\text { Risk Ratio } \\
\text { M- } \\
\mathrm{H}, \text { Random,95\% } \\
\mathrm{Cl}\end{array}$ & Weight & $\begin{array}{c}\text { Risk Ratio } \\
\text { M- } \\
\text { H,Random,95\% } \\
\text { Cl }\end{array}$ \\
\hline \multicolumn{7}{|l|}{ I Arrests } \\
\hline Kinlock 2005 & $8 / 24$ & $21 / 38$ & & & $100.0 \%$ & $0.60[0.32,1.14]$ \\
\hline Subtotal $(95 \% \mathrm{CI})$ & 24 & 38 & & & $100.0 \%$ & $0.60[0.32,1.14]$ \\
\hline \multicolumn{7}{|c|}{ Total events: 8 (Pharmacological), 21 (No pharmacological) } \\
\hline \multicolumn{7}{|c|}{ Heterogeneity: not applicable } \\
\hline \multicolumn{7}{|c|}{ Test for overall effect: $Z=1.56(P=0.12)$} \\
\hline \multicolumn{7}{|l|}{2 Re-incarceration } \\
\hline Dolan 2003 & $143 / 19 \mid$ & $137 / 191$ & & & $45.4 \%$ & $1.04[0.92,1.18]$ \\
\hline Dole 1969 & $3 / 12$ & $15 / 16$ & & $\rightarrow$ & $25.6 \%$ & $0.27[0.10,0.72]$ \\
\hline Kinlock 2005 & $7 / 24$ & $9 / 38$ & & 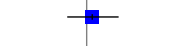 & $29.0 \%$ & $1.23[0.53,2.87]$ \\
\hline Subtotal (95\% CI) & 227 & 245 & & & $100.0 \%$ & $0.77[0.36,1.64]$ \\
\hline \multicolumn{7}{|c|}{ Total events: I53 (Pharmacological), I6I (No pharmacological) } \\
\hline \multicolumn{7}{|c|}{ Heterogeneity: $\operatorname{Tau}^{2}=0.32 ; \mathrm{Chi}^{2}=7.79, \mathrm{df}=2(\mathrm{P}=0.02) ; \mathrm{I}^{2}=74 \%$} \\
\hline \multicolumn{7}{|c|}{ Test for overall effect: $Z=0.67(P=0.50)$} \\
\hline \multicolumn{7}{|c|}{ Test for subgroup differences: $\mathrm{Chi}^{2}=0.24, \mathrm{df}=\mathrm{I}(\mathrm{P}=0.62), \mathrm{I}^{2}=0.0 \%$} \\
\hline & & & 0.01 & 0.1 & 100 & \\
\hline & & & Favou & agonist & o pharm & \\
\hline
\end{tabular}


Analysis I.5. Comparison I Agonist pharmacological vs no intervention, Outcome 5 Criminal activity continuous.

Review: Pharmacological interventions for drug-using offenders

Comparison: I Agonist pharmacological vs no intervention

Outcome: 5 Criminal activity continuous

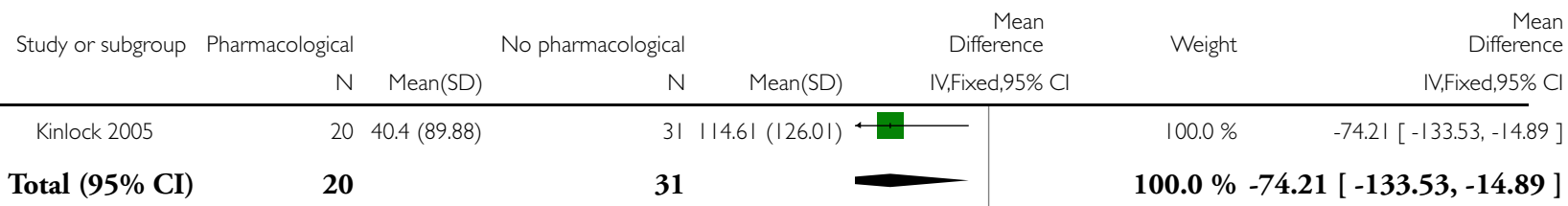

Heterogeneity: not applicable

Test for overall effect: $Z=2.45(P=0.014)$

Test for subgroup differences: Not applicable

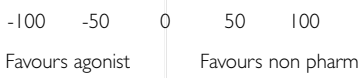

\section{Analysis 2.I. Comparison 2 Antagonist (Naltrexone) vs no pharmacological, Outcome I Criminal activity} dichotomous.

Review: Pharmacological interventions for drug-using offenders

Comparison: 2 Antagonist (Naltrexone) vs no pharmacological

Outcome: I Criminal activity dichotomous

Control Risk Ratio

Weight

H,Random, $95 \%$

Cl

Risk Ratio

$\mathrm{H}$, Random, $95 \%$

\begin{tabular}{ccc} 
& $\mathrm{n} / \mathrm{N}$ & $\mathrm{n} / \mathrm{N}$ \\
\hline I Reincarceration & & \\
Cornish 1997 & $9 / 34$ & $10 / 1$ \\
Coviello 2010 & $2 / 31$ & $9 / 32$
\end{tabular}

Subtotal $(95 \% \mathrm{CI})$

65

49

(1)

$\longrightarrow$

Total events: II (Naltrexone), 19 (Control)

Heterogeneity: $\mathrm{Tau}^{2}=0.0 ; \mathrm{Chi}^{2}=0.77, \mathrm{df}=\mathrm{I}(\mathrm{P}=0.38) ; \mathrm{I}^{2}=0.0 \%$

Test for overall effect: $Z=2.91(P=0.0036)$

Test for subgroup differences: Not applicable

$\begin{array}{ll}81.7 \% & 0.45[0.23,0.89] \\ 18.3 \% & 0.23[0.05,0.98]\end{array}$

$100.0 \%$

$0.40[0.21,0.74]$

\section{$\begin{array}{lllll}0.01 & 0.1 & 1 & 10 & 100\end{array}$}

Favours naltrexone

Favours non pharm

Pharmacological interventions for drug-using offenders (Review) 


\section{Analysis 2.2. Comparison 2 Antagonist (Naltrexone) vs no pharmacological, Outcome 2 drug use}

(objective).

Review: Pharmacological interventions for drug-using offenders

Comparison: 2 Antagonist (Naltrexone) vs no pharmacological

Outcome: 2 drug use (objective)

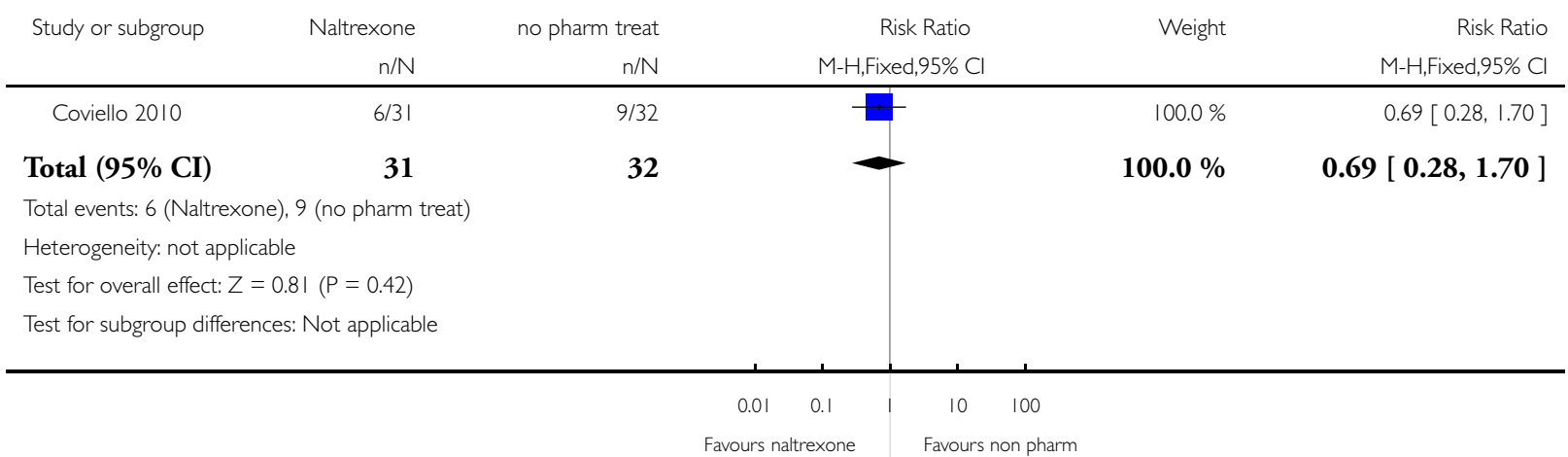


Analysis 3.I. Comparison 3 Methadone vs buprenorphine, Outcome I Self reported drug use dichotomous.

Review: Pharmacological interventions for drug-using offenders

Comparison: 3 Methadone vs buprenorphine

Outcome: I Self reported drug use dichotomous

Study or subgroup methadone Risk Ratio buprenorphine Weight

\begin{tabular}{|c|c|c|c|c|c|}
\hline & $\mathrm{n} / \mathrm{N}$ & $\mathrm{n} / \mathrm{N}$ & $\begin{array}{c}\text { M- } \\
\mathrm{H}, \text { Random,95\% } \\
\mathrm{Cl}\end{array}$ & & $\begin{array}{c}\text { M- } \\
\mathrm{H} \text {,Random,95\% } \\
\mathrm{Cl}\end{array}$ \\
\hline Magura 2009 & $25 / 38$ & $23 / 43$ & & $56.2 \%$ & $1.23[0.86,1.76]$ \\
\hline Wright 201। & $27 / 148$ & $31 /|4|$ & 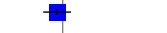 & $43.8 \%$ & $0.83[0.52,1.32]$ \\
\hline
\end{tabular}

Total $(95 \% \mathrm{CI}) \quad 186$

$84 \quad 100.0 \%$

$1.04[0.69,1.55]$

Total events: 52 (methadone), 54 (buprenorphine)

Heterogeneity: $\operatorname{Tau}^{2}=0.04 ; \mathrm{Chi}^{2}=1.94, \mathrm{df}=\mathrm{I}(\mathrm{P}=0.16) ; \mathrm{I}^{2}=48 \%$

Test for overall effect: $Z=0.17(P=0.87)$

Test for subgroup differences: Not applicable

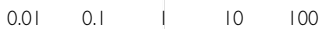

Favours methadone Favours buprenorphine

Analysis 3.2. Comparison 3 Methadone vs buprenorphine, Outcome 2 Self reported drug use continuous.

Review: Pharmacological interventions for drug-using offenders

Comparison: 3 Methadone vs buprenorphine

Outcome: 2 Self reported drug use continuous

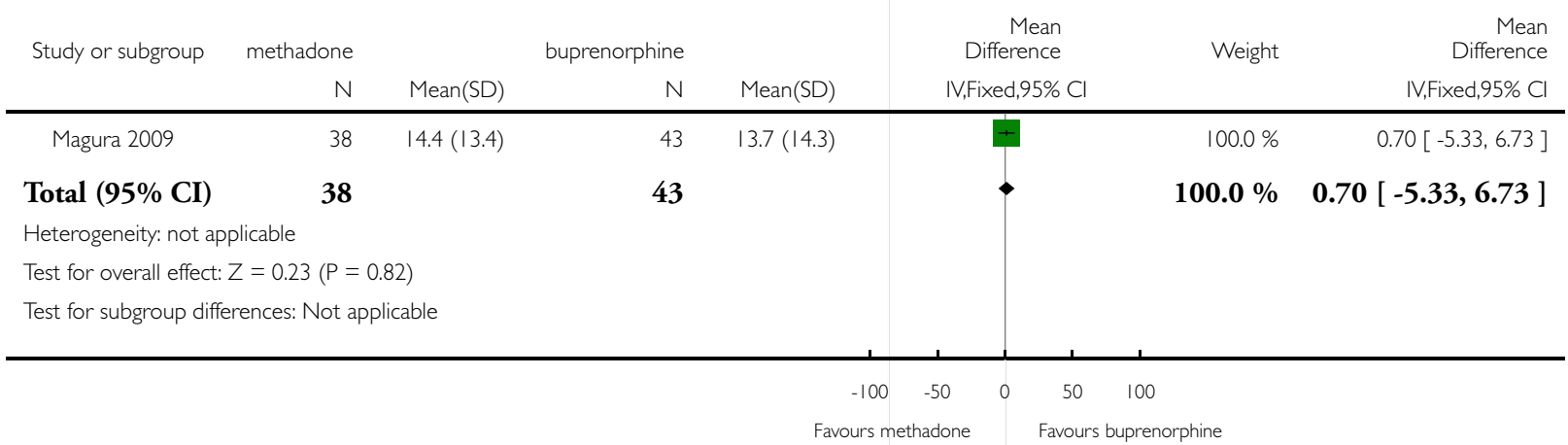


Analysis 3.3. Comparison 3 Methadone vs buprenorphine, Outcome 3 Criminal activity dichotomous.

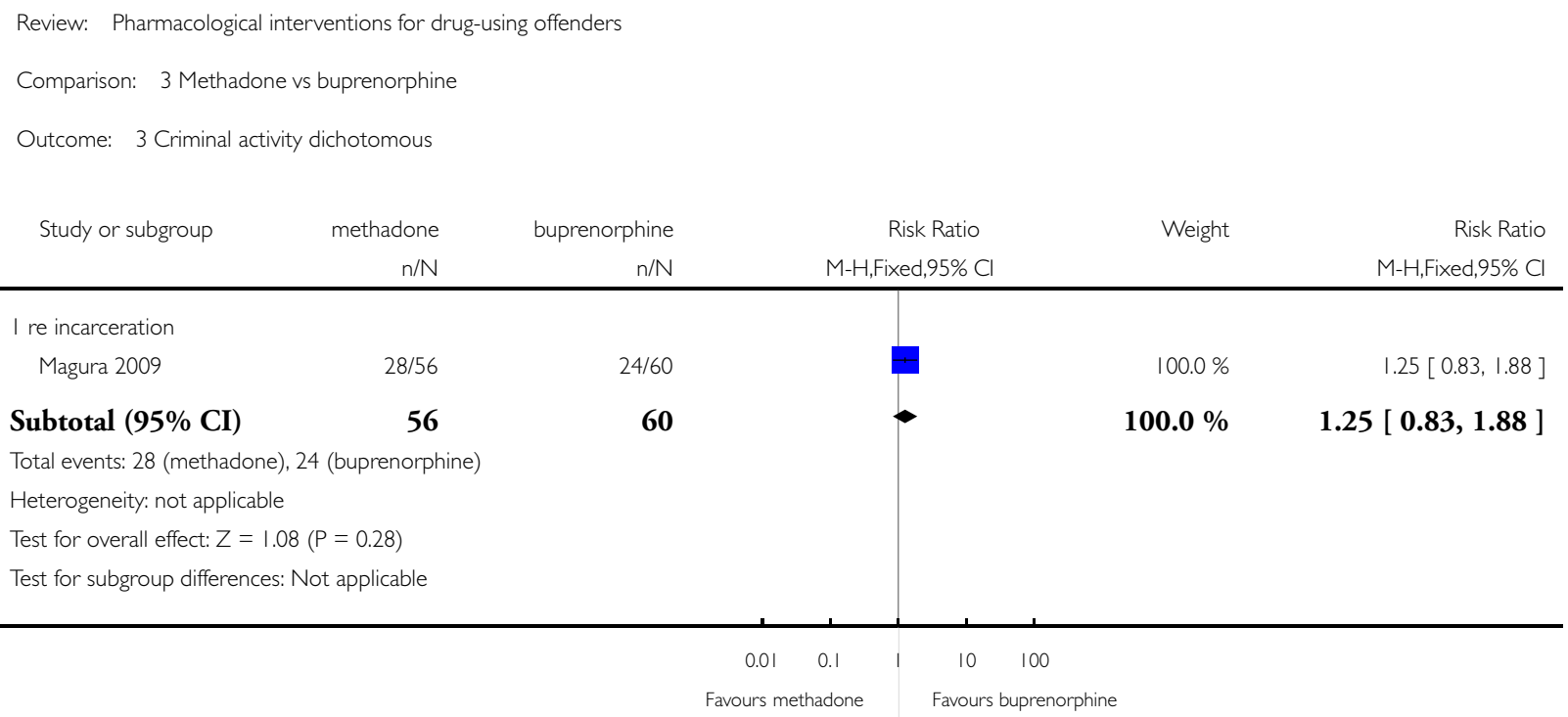

Analysis 4.I. Comparison 4 Methadone vs diamorphine, Outcome I criminal activity dichotomous.

Review: Pharmacological interventions for drug-using offenders

Comparison: 4 Methadone vs diamorphine

Outcome: I criminal activity dichotomous

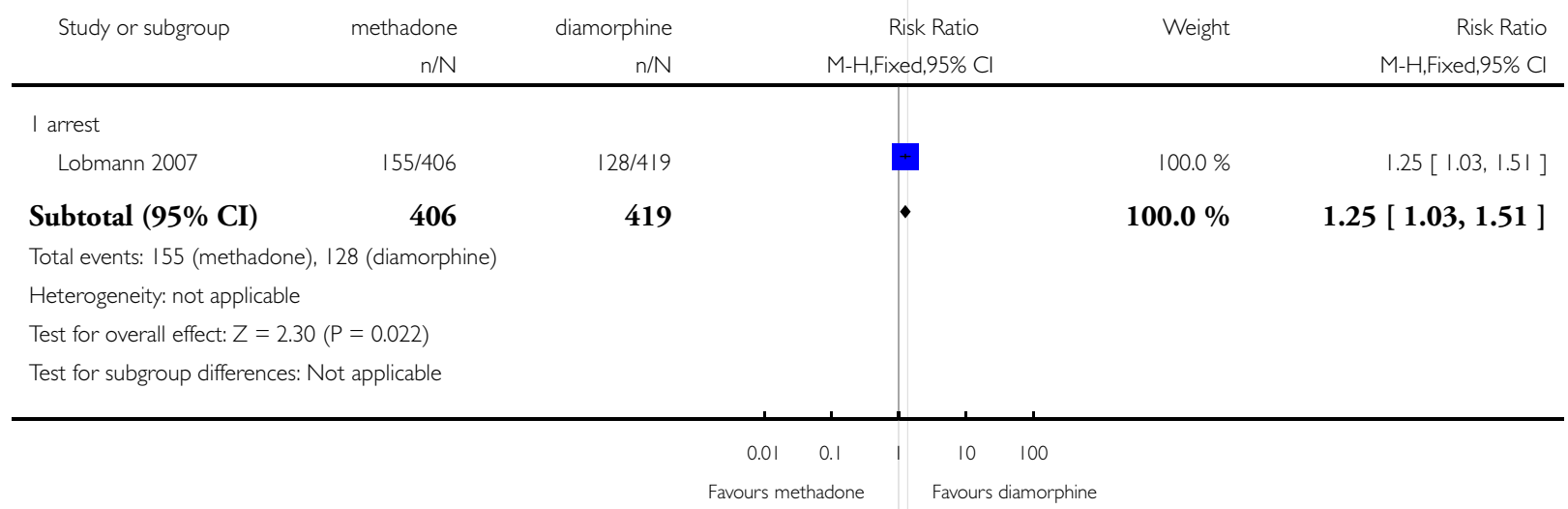


Analysis 5.I. Comparison 5 Methadone vs naltrexone, Outcome I self reported drug use continuous.

Review: Pharmacological interventions for drug-using offenders

Comparison: 5 Methadone vs naltrexone

Outcome: I self reported drug use continuous

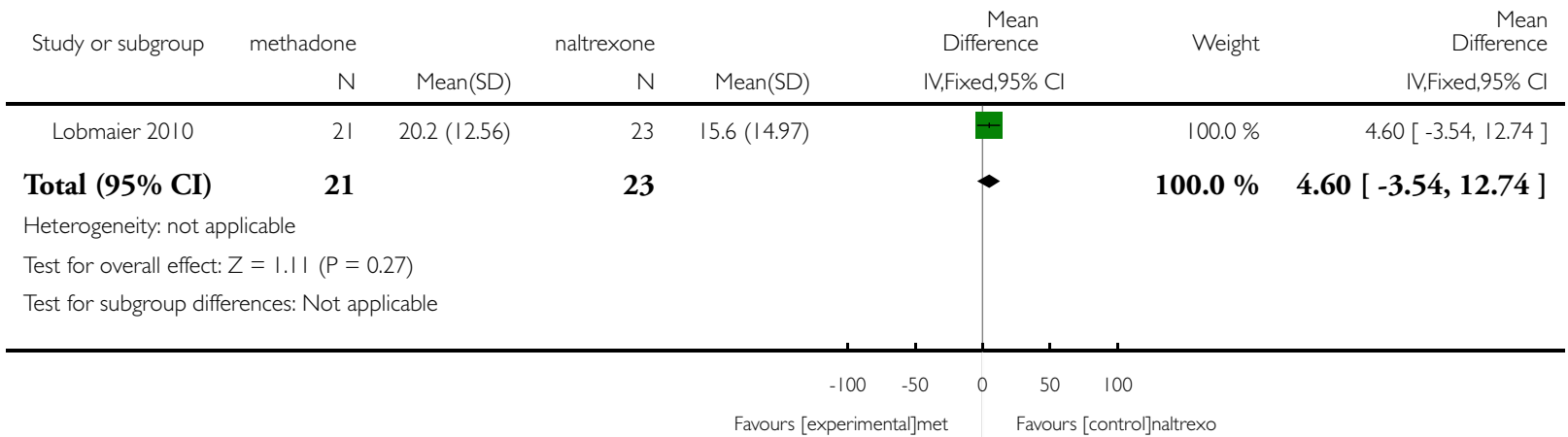

Analysis 5.2. Comparison 5 Methadone vs naltrexone, Outcome 2 criminal activity dichotomous.

Review: Pharmacological interventions for drug-using offenders

Comparison: 5 Methadone vs naltrexone

Outcome: 2 criminal activity dichotomous

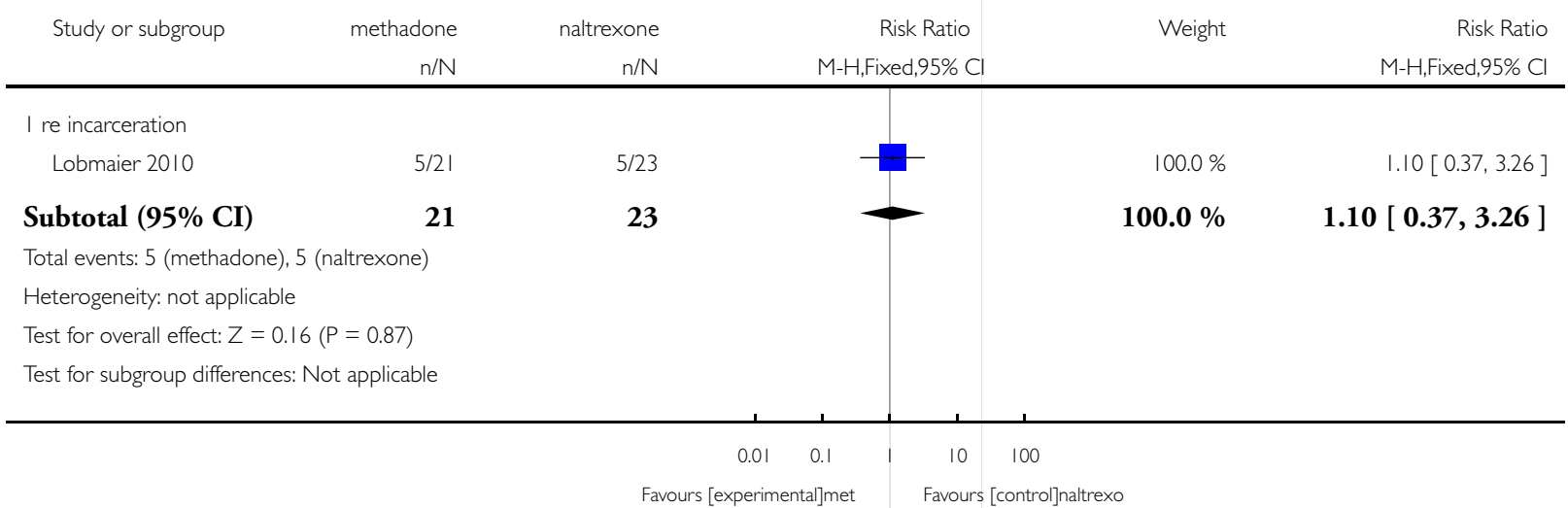




\section{Analysis 5.3. Comparison 5 Methadone vs naltrexone, Outcome 3 criminal activity continuous.}

Review: Pharmacological interventions for drug-using offenders

Comparison: 5 Methadone vs naltrexone

Outcome: 3 criminal activity continuous

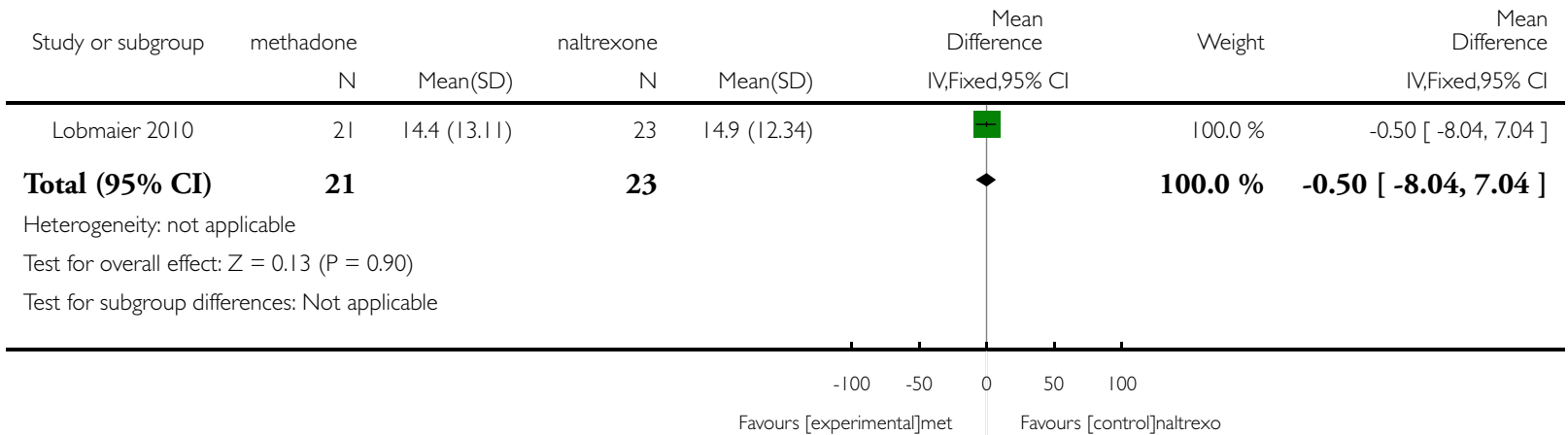

\section{ADDITIONAL TABLES}

Table 1. Table 1 summary of outcomes and comparisons

\begin{tabular}{|c|c|c|c|c|c|c|}
\hline Study & Setting & Intervention & $\begin{array}{l}\text { Comparison } \\
\text { group }\end{array}$ & $\begin{array}{l}\text { Follow-up } \\
\text { period }\end{array}$ & Outcome type & $\begin{array}{l}\text { Outcome } \\
\text { description }\end{array}$ \\
\hline $\begin{array}{l}\text { Bayanzadeh } \\
2004\end{array}$ & Prison & $\begin{array}{l}\text { Methadone treat- } \\
\text { ment in combina- } \\
\text { tion with } \\
\text { CBT and widely } \\
\text { focused on cop- } \\
\text { ing and problem- } \\
\text { solving skills }\end{array}$ & $\begin{array}{l}\text { Non-meth- } \\
\text { adone drugs plus } \\
\text { standard psychi- } \\
\text { atric services and } \\
\text { therapeutic medi- } \\
\text { cations }\end{array}$ & 6 months & $\begin{array}{ll}\text { Biological drug } \\
\text { use } \\
\text { Self-report drug } \\
\text { use }\end{array}$ & $\begin{array}{l}\text { Drug use yes/no } \\
\text { Frequency } \\
\text { of drug injections } \\
\text { (percentage) } \\
\text { Syringe sharing } \\
\text { Morphine urine } \\
\text { analysis }\end{array}$ \\
\hline Brown 2013 & Community & Methadone & $\begin{array}{l}\text { Primary care plus } \\
\text { sub- } \\
\text { oxone (buprenor- } \\
\text { phine and nalox- } \\
\text { one) }\end{array}$ & $\begin{array}{l}6 \text { months } \\
12 \text { months }\end{array}$ & $\begin{array}{l}\text { Biological drug } \\
\text { use } \\
\text { Self report drug } \\
\text { use }\end{array}$ & $\begin{array}{l}\text { Fre- } \\
\text { quency and pat- } \\
\text { tern of daily drug } \\
\text { use } \\
\text { Addiction Sever- } \\
\text { ity Index (self re- } \\
\text { port). } \\
\text { Lite, HIV risk be- } \\
\text { haviours (RAB - } \\
\text { Risk Assessment } \\
\text { Battery short ver- }\end{array}$ \\
\hline
\end{tabular}


Table 1. Table 1 summary of outcomes and comparisons (Continued)

\begin{tabular}{|c|c|c|c|c|c|c|}
\hline & & & & & & $\begin{array}{l}\text { sion), and health } \\
\text { services } \\
\text { utilization } \\
\text { Urine } \\
\text { drug screens were } \\
\text { collected as a part } \\
\text { of routine man- } \\
\text { agement }\end{array}$ \\
\hline Cornish 1997 & Community & Naltrexone & $\begin{array}{l}\text { Routine parole/ } \\
\text { probation }\end{array}$ & $\begin{array}{l}6 \text { months and } \\
\text { during } 6 \text { months } \\
\text { of treatment }\end{array}$ & $\begin{array}{l}\text { Criminal activity } \\
\text { dichotomous }\end{array}$ & $\begin{array}{l}\% \text { reincarcerated } \\
\text { during } 6 \text { months } \\
\text { of follow-up }\end{array}$ \\
\hline Coviello 2010 & Community & Naltrexone & $\begin{array}{l}\text { Psychosocial } \\
\text { treatment only }\end{array}$ & 6 months & $\begin{array}{l}\text { Biological drug } \\
\text { use dichotomous } \\
\text { Criminal activity } \\
\text { dichotomous }\end{array}$ & $\begin{array}{l}\% \text { positive urine } \\
\text { drug screen opi- } \\
\text { oids } \\
\% \text { positive urine } \\
\text { drug screen co- } \\
\text { caine } \\
\% \text { violating pa- } \\
\text { role/probation }\end{array}$ \\
\hline Cropsey 2011 & Community & Buprenorphine & Placebo & $\begin{array}{l}\text { End of treatment } \\
3 \text { months }\end{array}$ & $\begin{array}{l}\text { Biological drug } \\
\text { use dichotomous } \\
\text { Self-report drug } \\
\text { use dichotomous }\end{array}$ & $\begin{array}{l}\% \text { positive urine } \\
\text { opiates } \\
\% \text { self-report in- } \\
\text { jection drug use }\end{array}$ \\
\hline Dolan 2003 & Prison & $\begin{array}{l}\text { Pharmacological } \\
\text { (methadone) }\end{array}$ & $\begin{array}{l}\text { Waiting list con- } \\
\text { trol }\end{array}$ & $\begin{array}{l}4 \text { months } \\
2 \text { months } \\
3 \text { months }\end{array}$ & $\begin{array}{l}\text { Biological drug } \\
\text { use continuous } \\
\text { Biological drug } \\
\text { use dichotomous } \\
\text { Self-report drug } \\
\text { use dichotomous }\end{array}$ & $\begin{array}{l}\% \text { hair positive } \\
\text { for morphine } \\
\% \text { self-reported } \\
\text { any injection } \\
\% \text { self-reported } \\
\text { heroin injection }\end{array}$ \\
\hline Dole 1969 & Prison & Methadone & $\begin{array}{l}\text { Waiting list con- } \\
\text { trol. }\end{array}$ & $\begin{array}{l}\text { At between } 7 \text { and } \\
10 \text { months } \\
\text { At } 50 \text { weeks }\end{array}$ & $\begin{array}{l}\text { Biological drug } \\
\text { use continuous } \\
\text { Biological drug } \\
\text { use dichotomous } \\
\text { Self-report drug } \\
\text { use dichotomous }\end{array}$ & $\begin{array}{l}\text { Heroin use } \\
\text { Reincarceration } \\
\text { Treatment reten- } \\
\text { tion } \\
\text { Employment }\end{array}$ \\
\hline Howells 2002 & Prison & $\begin{array}{l}\text { Methadone and } \\
\text { placebo }\end{array}$ & $\begin{array}{l}\text { Lofexidine and } \\
\text { placebo }\end{array}$ & Post treatment & $\begin{array}{l}\text { Self report data } \\
\text { on withdrawl } \\
\text { Severity of psy- } \\
\text { chological depen- } \\
\text { dence }\end{array}$ & $\begin{array}{l}\text { With- } \\
\text { drawal symptom } \\
\text { severity measured } \\
\text { using two with- } \\
\text { drawal scales: the } \\
\text { 20-item With- } \\
\text { drawal Problems }\end{array}$ \\
\hline
\end{tabular}

Pharmacological interventions for drug-using offenders (Review) 
Table 1. Table 1 summary of outcomes and comparisons (Continued)

\begin{tabular}{|c|c|c|c|c|c|c|}
\hline & & & & & & $\begin{array}{l}\text { Scale (WPS), and } \\
\text { the eight item } \\
\text { Short Opiate } \\
\text { Withdrawal Scale } \\
\text { (SOWS) } \\
\text { Secondary out- } \\
\text { come measures } \\
\text { were rates and } \\
\text { timing of with- } \\
\text { drawal from the } \\
\text { detoxifica- } \\
\text { tion programme } \\
\text { so that the rela- } \\
\text { tionship between } \\
\text { failure to com- } \\
\text { plete detoxifica- } \\
\text { tion and sever- } \\
\text { ity of withdrawal } \\
\text { symptoms could } \\
\text { be measured } \\
\text { The Severity of } \\
\text { Dependency } \\
\text { Scale (SDS) was } \\
\text { also used to as- } \\
\text { sess the severity of } \\
\text { psychological as- } \\
\text { pects of drug de- } \\
\text { pendence }\end{array}$ \\
\hline Kinlock 2007 & Prison & $\begin{array}{l}\text { Counselling } \\
+ \text { methadone ini- } \\
\text { tiation pre-release } \\
\text { (a) and post-re- } \\
\text { lease (b) }\end{array}$ & Counselling only & $\begin{array}{l}1 \text { month } \\
3 \text { months } \\
6 \text { months } \\
12 \text { months }\end{array}$ & $\begin{array}{l}\text { Biological drug } \\
\text { use dichotomous } \\
\text { Self-report drug } \\
\text { use dichotomous } \\
\text { Criminal activity } \\
\text { dichotomous }\end{array}$ & $\begin{array}{l}\% \text { positive for } \\
\text { urine opioids } \\
\% \text { positive for } \\
\text { urine cocaine } \\
\% \text { self-reported } 1 \\
\text { or more days } \\
\text { heroin } \\
n \text { used heroin for } \\
\text { entire 180-day } \\
\text { follow-up period } \\
\text { Re-incarcerated } \\
\text { Self-reported } \\
\text { criminal activity }\end{array}$ \\
\hline Kinlock 2005 & Prison & $\begin{array}{l}\text { Prison based levo } \\
\text { alpha } \\
\text { acetyl methanol } \\
\text { and transfer to } \\
\text { methadone after } \\
\text { release }\end{array}$ & $\begin{array}{l}\text { untreated } \\
\text { controls }\end{array}$ & During 9 months & $\begin{array}{l}\text { Biological drug } \\
\text { use dichotomous } \\
\text { Self-report drug } \\
\text { use dichotomous } \\
\text { Criminal activity } \\
\text { dichotomous }\end{array}$ & $\begin{array}{l}\text { Heroin use } \\
\text { Arrest } \\
\text { Re incarceration } \\
\text { Frequency of ille- } \\
\text { gal activity } \\
\text { Admission drug }\end{array}$ \\
\hline
\end{tabular}

Pharmacological interventions for drug-using offenders (Review) 
Table 1. Table 1 summary of outcomes and comparisons (Continued)

\begin{tabular}{|c|c|c|c|c|c|c|}
\hline & & & & & & $\begin{array}{l}\text { use } \\
\text { Average weekly } \\
\text { income }\end{array}$ \\
\hline Lobmaier 2010 & Prison & Naltrexone & Methadone & 6 months & $\begin{array}{l}\text { Criminal activity } \\
\text { continuous } \\
\text { Criminal activity } \\
\text { dichotomous } \\
\text { Self-report drug } \\
\text { use continuous }\end{array}$ & $\begin{array}{l}\text { Mean days of } \\
\text { criminal activity } \\
\% \text { re-incarcerated } \\
\text { Mean days of } \\
\text { heroin use } \\
\text { Mean } \\
\text { days of benzodi- } \\
\text { azepine use } \\
\text { Mean days of am- } \\
\text { phetamine use }\end{array}$ \\
\hline Lobmann 2007 & Community & $\begin{array}{l}\text { Pharmacological } \\
\text { (diamorphine) }\end{array}$ & Methadone & 12 months & $\begin{array}{l}\text { Criminal activity } \\
\text { dichotomous }\end{array}$ & $\begin{array}{l}\% \text { self-reported } \\
\text { criminal activity } \\
\% \quad \text { police- } \\
\text { recorded offences }\end{array}$ \\
\hline Magura 2009 & Prison & Buprenorphine & Methadone & 3 months & $\begin{array}{l}\text { Criminal activity } \\
\text { dichotomous } \\
\text { Self-report drug } \\
\text { use continuous } \\
\text { Self-report drug } \\
\text { use dichotomous }\end{array}$ & $\begin{array}{l}\% \text { re-incarcerated } \\
\% \text { arrested for } \\
\text { property crime } \\
\% \text { arrested for } \\
\text { drug possession } \\
\text { Mean days of } \\
\text { heroin use } \\
\% \text { any heroin/ } \\
\text { opioid use }\end{array}$ \\
\hline Wright 2011 & Prison & Buprenorphine & Methadone & $\begin{array}{l}1 \text { month } \\
3 \text { months } \\
6 \text { months post } \\
\text { detoxification }\end{array}$ & $\begin{array}{l}\text { Biological drug } \\
\text { test } \\
\text { Self report official } \\
\text { drug records }\end{array}$ & $\begin{array}{l}\text { Abstinence from } \\
\text { illicit opiates at } 8 \\
\text { days post detoxi- } \\
\text { fication, as indi- } \\
\text { cated by a urine } \\
\text { test } \\
\text { If the participant } \\
\text { had been re- } \\
\text { leased, local com- } \\
\text { munity drugs ser- } \\
\text { vice records were } \\
\text { accessed to verify } \\
\text { abstinence }\end{array}$ \\
\hline
\end{tabular}


A P PENDICES

\section{Appendix I. MEDLINE search strategy}

\section{MEDLINE search}

1. exp "Substance-Related-Disorders"/

2. ((drug or substance) adj (abuse* or addict* or dependen* $^{*}$ or misuse $\left.\left.{ }^{*}\right)\right) . t i, a b$

3. (drug* adj (treat* or intervention* or program*)

4. substance near (treat* or intervention* or program*)

5.(detox* or methadone) in ti,ab

6. narcotic* near (treat* or intervention* or program*)

7. 1 or 2 or 3 or 4 or 5 or 6

8. prison*. ti,ab

9. exp "Prisoners"/

10. offender* or criminal* or inmate* or convict* or probation* or remand or felon*).ti,ab

11. exp "Prisons"/

12. 8 or 9 or 10 or 11

13.7 and 12

Appendix 2. EMBASE search strategy

\section{Embase search}

1. (detox $\$$ or methadone or antagonist prescri $\$) . t i, a b$.

2. detoxification/ or drug detoxification/ or drug withdrawal/ or drug dependence treatment/ or methadone/ or methadone treatment/ or diamorphine/ or naltrexone/

3. (diamorphine or naltrexone or therapeutic communit\$).ti,ab

4. morality/ 


\section{(Continued)}

5. (motivational interview $\$$ or motivational enhancement).ti,ab

6. (counselling or counseling).ti,ab.

7. exp counseling/

8. (psychotherap\$ or cognitive behavioral or cognitive behavioural).ti,ab

9. exp psychotherapy/

10. (moral adj3 training).ti,ab.

11. (cognitive restructuring or assertiveness training).ti,ab

12. reinforcement/ or self monitoring/ or self control/

13. (relaxation training or rational emotive or family relationship therap\$).ti,ab

14. social learning/ or withdrawal syndrome/ or coping behavior/

15. (community reinforcement or self monitoring or self control or self management or interpersonal skills).ti,ab

16. (goal\$ adj3 setting).ti,ab.

17. (social skills adj3 training).ti,ab.

18. anger/ or lifestyle/

19. (basic skills adj3 training).ti,ab.

20. (relapse adj3 prevent\$).ti,ab.

21. (craving adj3 (minimi $\$$ or reduc $\$)$ ).ti,ab.

22. (trigger or triggers or coping skills or anger management or group work).ti,ab

23. (lifestyle adj3 modifis).ti,ab.

24. (high intensity training or resettlement or throughcare or aftercare or after care).ti,ab

25. aftercare/ or halfway house/

26. (brief solution or brief intervention $\$$ or minnesota program $\$$ or 12 step $\$$ or twelve step\$).ti, ab

27. (needle exchange or nes or syringe exchange or dual diagnosis or narcotics anonymous).ti,ab 


\section{(Continued)}

28. self help/ or support group/

29. (self-help or selfhelp or self help or outreach or bail support or arrest referral\$).ti,ab

30. exp urinalysis/ or rehabilitation/ or rehabilitation center/

31. (diversion or dtto or dttos or drug treatment or testing order\$ or carat or carats).ti,ab

32. (combined orders or drug-free or drug free).ti,ab.

33. (peer support or evaluation $\$$ or urinalysis or drug testing or drug test or drug tests).ti,ab

34. ((rehab or rehabilitation or residential or discrete) adj2 (service\$ or program\$)).ti,ab

35. (asro or addressing substance $\$$ or pasro or prisons addressing or acupuncture or shock or boot camp or boot camps).ti,ab

36. (work ethic camp\$ or drug education or tasc or treatment accountability).ti,ab

37. exp acupuncture/

38. or/1-36

39. (remand or prison or prisoner or prisoners or offender $\$$ or criminal $\$$ or probation or court or courts).ti,ab

40. (secure establishment\$ or secure facilit\$).ti,ab.

41. (reoffend $\$$ or reincarcerat $\$$ or recidivi $\$$ or ex-offender $\$$ or jail or jails or goal or goals).ti,ab

42. (incarcerat $\$$ or convict or convicts or convicted or felon or felons or conviction $\$$ or revocation or inmate $\$$ or high security).ti,ab

43. criminal justice/ or custody/ or detention/ or prison/ or prisoner/ or offender/ or probation/ or court/ or recidivism/ or crime/ or criminal behavior/ or punishment/

44. or/39-43

45. 38 and 44

46. (substance abuse\$ or substance misuse $\$$ or substance use $\$$ ).ti,ab

47. (drug dependanc\$ or drug abuse $\$$ or drug use $\$$ or drug misuse $\$$ or drug addict $\$$ ).ti, ab

48. (narcotics adj3 (addict\$ or use $\$$ or misuse $\$$ or abuse\$)).ti,ab

49. (chemical dependanc $\$$ or opiates or heroin or crack or cocaine or amphetamines or addiction or dependance disorder or drug involved).ti,ab 


\section{(Continued)}

50. substance abuse/ or drug abuse/ or analgesic agent abuse/ or drug abuse pattern/ or drug misuse/ or intravenous drug abuse/ or multiple drug abuse/

51. addiction/ or drug dependence/ or narcotic dependence/ or exp narcotic agent/ or narcotic analgesic agent/

52. opiate addiction/ or heroin dependence/ or morphine addiction/

53. cocaine/ or amphetamine derivative/ or psychotropic agent/

54. or/46-53

55.45 and 54

\section{Appendix 3. Psyclnfo search strategy}

\section{PsycInfo}

1. (detoxification in de) or (drug withdrawal in de)

2. (drug usage screening in de) or (methadone maintenance) in de

3. explode "Narcotic-Antagonists" in DE

\section{1 or 2 or 3}

5. (counseling in de) or (explode "psychotherapeutic-counseling" in de)

6. (explode "cognitive-therapy" in de) or (explode "psychotherapeutic-techniques" in de)

7. (cognitive restructuring in de) or (assertiveness training in de)

8. explode "relaxation-therapy" in de

9. (rational emotive therapy in de) or (rational-emotive therapy in de)

10. (explode "self monitoring" in de) or (explode self-monitoring) in de

11. (goal setting in de) or (self control in de) or (explode "self-management" in de)

12. (social skills in de) or (relapse prevention in de) or (craving in de) or (coping behavior in de)

13. (anger control in de) or (explode "group-psychotherapy" in de) or (brief psychotherapy in de)

14. (explode "behavior-modification" in de) or (posttreatment followup in de) or (aftercare in de) 


\section{(Continued)}

15. (halfway houses in de) or (twelve step programs in de)

16. (dual diagnoses in de) or (explode "self help techniques" in de) or (outreach programs in de) or (court referrals in de)

17. (peer pressure in de) or (urinalysis in de)

18. (drug rehabilitation in de) or (residential care institutions in de) or (acupuncture in de) or (drug education in de)

19. (detox* or methadone or antagonist prescri* or diamorphine or naltrexone or therapeutic communit*) in ti,ab

20. (motivational interview* or motivational enhancemen* or counseling or psychotherapy or psychotherapies) in ti,ab

21. (cognitive behav* or cognitive therapy or cognitive therapies or moral training or cognitive restructuring) in ti,ab

22. (assertiveness training or relaxation training or relaxation therapy or relaxation therapies) in ti,ab

23. (rational emotive therap* or rational emotive behav* therap* or family relationship therap* or community reinforcement) in ti,ab

24. (self-monitor* or self monitor* or goal setting or self control or self-control or self management or self-management) in ti,ab

25. (interpersonal skills training or social skills training or basic skills training) in ti,ab

26. (relapse with prevent ${ }^{*}$ ) in ti,ab

27. (craving near reduc*) in ti,ab

28. craving with (reduc* in ti,ab)

29. (trigger* or coping skills or anger management or group work or lifestyle modif* or high intensity training or resettlement) in ti, $\mathrm{ab}$

30. (throughcare or aftercare or after care or brief solution* or brief intervention*) in ti,ab

31. (minnesota or 12 step* $^{*}$ or twelve step* or needle exchange or nes or syringe exchange or dual diagnosis) in ti,ab

32. (narcotics anonymous or self-help or self help or outreach or bail support or arrest referral*) in ti,ab

33. (diversion or dtto* or testing order* or carat* or counseling assessment referral or combined order or combined orders or drug free wing* or drug free environment $\left.{ }^{*}\right)$ in ti,ab

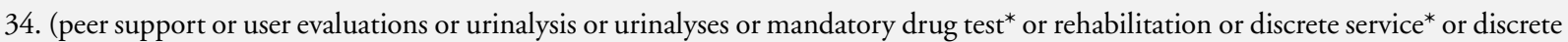
program $\left.^{*}\right)$ in ti,ab

35. (residential program* or residential scheme* or asro or addressing substance* or pasro or prisons addressing substance) in ti,ab

36. (acupuncture or shock or boot camp* or work ethic or drug education or tasc or treatment accountability) in ti,ab 


\section{(Continued)}

\section{7. or/4-36}

38. (secure facilities or convict* or revocation or inmate* or high security) in ti,ab

39. (prisoners in de) or (explode "correctional-institutions" in de)

40. (perpetrators in de) or (explode criminals in de)

41. (probation in de) or (parole in de) or (incarceration in de) or (recidivism in de) or (criminal conviction in de) or (crime in de)

42. (remand or prison* or offender* or criminal* or probation or court or courts or secure establishment* or reoffend* or reincarcerat* or recidivi* or ex-offender* or jail or jails or incarcerat $\left.{ }^{*}\right)$ in ti,ab

43. (drug abuse in de) or (explode "inhalant-abuse" in de) or (explode "drug-dependency" in de)

44. (polydrug abuse in de) or (drug abuse in de) or (intravenous drug usage in de)

45. (narcotic drugs in de) or (heroin in de) or (cocaine in de) or (explode amphetamine in de)

46. (substance abuse* or substance misuse* or substance user*) in ti,ab

47. (drug dependen* or drug abuse* or drug misuse* or drug addict* or drug use) in ti,ab

48. (narcotic abuse* or narcotic misuse* or chemical dependen* or opiate misuse* or opiate abuse*) in ti,ab

49. (heroin use* or heroin addict* or heroin misuse* or heroin abuse*) in ti,ab

50. (crack use* or crack addict* or crack misuse* or crack abuse*) in ti,ab

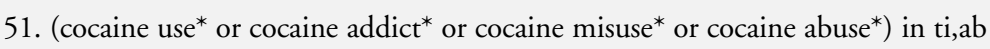

52. (amphetamine* use $^{*}$ or amphetamine* addict* $^{*}$ or amphetamine* misuse* or amphetamine* abuse*) in ti,ab

53. (dependence disorder or drug involved or dug-involved) in ti,ab

54. \#38 or \#39 or \#40 or \#41 or \#42

55 . $\# 4$ or $\# 43$ or $\# 44$ or $\# 45$ or $\# 46$ or $\# 47$ or $\# 48$ or $\# 49$ or $\# 50$ or $\# 51$ or $\# 52$ or $\# 53$

56. \#37 and \#54 and \#55 


\section{Appendix 4. SPECTRA search strategy}

\section{SPECTRA search}

1. $\{$ remand $\}$ or $\{$ prison $\}$ or $\{$ offender $\}$ or $\{$ criminal $\}$ or $\{$ probation $\}$ or $\{$ court $\}$ or $\{$ tribunal $\}$ or $\{$ secure establishment $\}$ or $\{$ secure facilit $\}$ or \{reoffend $\}$ or $\{$ reincarcerat $\}$ or $\{$ recidivi $\}$ or $\{$ ex-offender $\}$ or $\{$ jail $\}$ or $\{$ incarcerat $\}$ or $\{$ convict $\}$ or $\{$ felon $\}$ or $\{$ reconvict $\}$ or $\{$ high security $\}$ or $\{$ law enforcement $\}$

\{remand or $\{$ prison $\}$ or $\{$ offender $\}$ or $\{$ criminal or $\{$ probation\} or $\{$ court $\}$ or $\{$ tribunal $\}$ or $\{$ secure establishment $\}$ or $\{$ secure facilit $\}$ or \{reoffend $\}$ or $\{$ reincarcerat $\}$ or $\{$ recidivi $\}$ or $\{$ ex-offender $\}$ or $\{$ jail $\}$ or $\{$ incarcerat $\}$ or $\{$ convict $\}$ or $\{$ felon $\}$ or $\{$ reconvict $\}$ or $\{$ high security $\}$ or $\{$ law enforcement $\}$

2. $\{$ substance $\}$ or $\{$ dependenc $\}$ or $\{$ drug abuse $\}$ or $\{$ drug use $\}$ or $\{$ drug misuse $\}$ or \{addict $\}$

All indexed fields: $\{$ remand or $\{$ prison\} or $\{$ offender $\}$ or $\{$ criminal $\}$ or $\{$ probation $\}$ or $\{$ court $\}$ or $\{$ tribunal $\}$ or $\{$ secure establishment $\}$ or $\{$ secure facilit $\}$ or $\{$ reoffend $\}$ or $\{$ reincarcerat $\}$ or $\{$ recidivi $\}$ or $\{$ ex-offender $\}$ or $\{$ jail $\}$ or $\{$ incarcerat $\}$ or $\{$ convict $\}$ or $\{$ felon $\}$ or $\{$ reconvict $\}$ or $\{$ high security\} or $\{$ law enforcement $\}$

OR

All unindexed fields: $\{$ remand or $\{$ prison $\}$ or $\{$ offender $\}$ or $\{$ criminal $\}$ or $\{$ probation $\}$ or $\{$ court $\}$ or $\{$ tribunal $\}$ or $\{$ secure establishment $\}$ or $\{$ secure facilit $\}$ or $\{$ reoffend $\}$ or $\{$ reincarcerat $\}$ or $\{$ recidivi $\}$ or $\{$ ex-offender $\}$ or $\{$ jail $\}$ or $\{$ incarcerat $\}$ or $\{$ convict $\}$ or $\{$ felon $\}$ or $\{$ reconvict $\}$ or $\{$ high security\} or $\{$ law enforcement $\}$

AND

All unindexed fields: \{substance or $\{$ dependenc\} or $\{$ drug abuse $\}$ or $\{$ drug use $\}$ or $\{$ drug misuse $\}$ or $\{$ addict $\}$ or $\{$ narcotics $\}$ or $\{$ opiates\} or $\{$ heroin $\}$ or $\{$ crack $\}$ or $\{$ cocaine $\}$ or $\{$ amphetamines\} or $\{$ drug involved $\}$ or $\{$ substance-related or $\{$ amphetamine-related or $\{$ cocainerelated or $\{$ marijuana $\}$ or $\{$ opioid $\}$ or $\{$ street drug\} or $\{$ designer drug\}

\section{3. narcotics}

\section{4. opiates}

\section{5. heroin}

6. $\{$ crack $\}$

7. cocaine

\section{8. amphetamines}

9. drug involved

10. substance-related

11. amphetamine-related

12. cocaine-related

13. marijuana

14. opioid

Pharmacological interventions for drug-using offenders (Review) 
(Continued)

15. street drug

16. designer drug

17. 2 or 3 or 4 or 5 or 6 or 7 or 8 or 9 or 10 or 11 or 12 or 13 or 14 or 15 or 16

18. 1 AND 17

\section{Appendix 5. PASCAL. SciSearch, Social SciSSciSearch, Wilson Applied Science and Technology} Abstracts search strategy

PASCAL search

1. (DETOX? OR METHADONE OR ANTAGONIST()PRESCRI?)/TI,AB

2. METHADONE/DE OR NALTREXONE/DE

3. (DIAMORPHINE OR NALTREXONE)/TI,AB

4. THERAPEUTIC()COMMUNITY/DE OR THERAPEUTIC()COMMUNIT?)/TI,AB

5. (MOTIVATIONAL()INTERVIEW? OR MOTIVATIONAL()ENHANCEMENT)/TI,AB

6. (COUNSELLING OR COUNSELING)/TI,AB

7. COUNSELING/DE

8. (PSYCHOTHERAP? OR COGNITIVE()BEHAVIORAL OR COGNITIVE()BEHAVIOURAL)/TI,AB

9. PSYCHOTHERAPY!/DE

10. (MORAL(3W)TRAINING)/TI,AB

11. (COGNITIVE()RESTRUCTURING OR ASSERTIVENESS()TRAINING)/TI,AB

12. ASSERTIVENESS/DE OR RELAXATION()TECHNIQUES/DE

13. (RELAXATION()TRAINING OR RATIONAL()EMOTIVE OR FAMILY()RELATIONSHIP()THERAP?)/TI,AB

14. FAMILY()RELATIONS/DE

15. (COMMUNITY()REINFORCEMENT OR SELF()MONITORING OR SELF()CONTROL OR SELF()MANAGEMENT OR INTERPERSONAL()SKILLS)/TI,AB

16. (GOAL?(3W)SETTING)/TI,AB

Copyright () 2015 The Cochrane Collaboration. Published by John Wiley \& Sons, Ltd. 
(Continued)

17. (SOCIAL(3W)TRAINING)/TI,AB

18. SOCIAL RESPONSIBILITY/DE

19. (BASIC()SKILLS(3W)TRAINING)/TI,AB

20. (RELAPSE(3W)PREVENT?)/TI,AB

21. (CRAVING(3W)(MINIMI? OR REDUC?))/TI,AB

22. (TRIGGER OR TRIGGERS OR COPING()SKILLS OR ANGER()MANAGEMENT OR GROUP()WORK)/TI,AB

23. (LIFESTYLE(3W)MODIFI?)/TI,AB

24. (HIGH()INTENSITY()TRAINING OR RESETTLEMENT OR THROUGHCARE OR AFTERCARE OR AFTER()CARE) /TI,AB

25. ADAPTATION,-PSYCHOLOGICAL!/DE OR ANGER/DE OR LIFE()STYLE/DE OR AFTER()CARE/DE OR HALFWAY ()HOUSES/DE

26. (BRIEF()SOLUTION OR BRIEF()INTERVENTION? OR MINNESOTA()PROGRAM? OR 12()STEP? OR TWELVE() $\mathrm{STEP}$ )/TI,AB

27. (NEEDLE()EXCHANGE OR NES OR SYRINGE()EXCHANGE OR DUAL()DIAGNOSIS OR NARCOTICS()ANONYMOUS)/TI,AB

28. NEEDLE-EXCHANGE()PROGRAMS/DE

29. (SELF-HELP OR SELFHELP OR SELF()HELP OR OUTREACH OR BAIL()SUPPORT OR ARREST()REFERRAL?)/TI, $\mathrm{AB}$

30. SELF-HELP()GROUPS/DE OR URINALYSIS/DE OR SUBSTANCE()ABUSE()DETECTION/DE

31. (DIVERSION OR DTTO OR DTTOS OR DRUG()TREATMENT OR TESTING()ORDER? ? OR CARAT OR CARATS) /TI,AB

32. (COMBINED()ORDERS OR DRUG-FREE OR DRUG()FREE)/TI,AB

33. (PEER()SUPPORT OR EVALUATION? ? OR URINALYSIS OR DRUG()TESTING OR DRUG()TEST? ?)/TI,AB

34. ((REHAB OR REHABILITATION OR RESIDENTIAL OR DISCRETE)(2W)(SERVICE? ? OR PROGRAM?))/TI,AB

35. (ASRO OR ADDRESSING()SUBSTANCE? OR PASRO OR PRISONS()ADDRESSING OR ACUPUNCTURE OR SHOCK OR BOOT()CAMP OR BOOT()CAMPS)/TI,AB

36. (WORK()ETHIC()CAMP? ? OR DRUG()EDUCATION OR TASC OR TREATMENT()ACCOUNTABILITY)/TI,AB

37. ACUPUNCTURE-THERAPY!/DE OR ACUPUNCTURE/DE OR HEALTH()EDUCATION/DE OR SUBSTANCE() ABUSE()TREATMENT()CENTERS/DE

Pharmacological interventions for drug-using offenders (Review) 
(Continued)

38. S1:S3

39. $S 4: S 37$

40. S38 AND S39

40. (REMAND OR PRISON OR PRISONER OR PRISONERS OR OFFENDER? ? OR CRIMINAL? ? OR PROBATION OR COURT OR COURTS)/TI,AB

41. (SECURE()ESTABLISHMENT? ? OR SECURE()FACILIT?)/TI,AB

42. (REOFFEND? OR REINCARCERAT? OR RECIDIVI? OR EX()OFFENDER? ? OR JAIL OR JAILS)/TI,AB

43. (INCARCERAT? OR CONVICT OR CONVICTS OR CONVICTED OR FELON? ? OR CONVICTION? ? OR REVOCATION OR INMATE? ? OR HIGH()SECURITY)/TI,AB

44. PRISONERS/DE OR LAW()ENFORCEMENT/DE OR JURISPRUDENCE/DE

45. S40:S44

46. S40 AND S45

47. (SUBSTANCE()ABUSE? OR SUBSTANCE()MISUSE? OR SUBSTANCE()USE?)/TI,AB

48. (DRUG()DEPENDANC? OR DRUG()ABUSE? OR DRUG()USE? OR DRUG()MISUSE? OR DRUG()ADDICT?)/TI,AB

49. (NARCOTICS(3W)(ADDICT? OR USE? OR MISUSE? OR ABUSE?))/TI,AB

50. (CHEMICAL()DEPENDANC? OR OPIATES OR HEROIN OR CRACK OR COCAINE OR AMPHETAMINES OR ADDICTION OR DEPENDENCE()DISORDER OR DRUG()INVOLVED)/TI,AB

51. SUBSTANCE-RELATED()DISORDERS/DE OR AMPHETAMINE-RELATED()DISORDERS/DE OR COCAINE-RELATED()DISORDERS/DE OR MARIJUANA ()ABUSE/DE

52. OPIOID-RELATED-DISORDERS!/DE OR PHENCYCLIDINE()ABUSE/DE OR SUBSTANCE()ABUSE()INTRAVENOUS/DE

53. STREET()DRUGS/DE OR DESIGNER()DRUGS/DE OR NARCOTICS/DE

54. COCAINE!/DE OR AMPHETAMINES!/DE OR ANALGESICS()OPIOID/DE

55. S47:S54

56. S46 AND S55

57. (DETOXIFICATION OR METHADONE OR ANTAGONIST-PRESCRIBING)/DE FROM 144,34,434,7,99,65,35,6

58. (DIAMORPHINE OR NALTREXONE)/DE FROM 144,34,434,7,99,65,35,6

Pharmacological interventions for drug-using offenders (Review) 
(Continued)

59. THERAPEUTIC-COMMUNITY)/DE FROM 144,34,434,7,99,65,35,6

60. (MOTIVATIONAL-INTERVIEW OR MOTIVATIONAL-ENHANCEMENT)/DE FROM 144,34,434,7,99,65,35,6

61. (COUNSELLING OR COUNSELING)/DE FROM 144,34,434,7,99,65,35,6

62. (PSYCHOTHERAPY! OR COGNITIVE-BEHAVIORAL OR COGNITIVE-BEHAVIOURAL)/DE FROM 144,34,434,7, $99,65,35,6$

63. (MORAL-TRAINING)/DE FROM 144,34,434,7,99,65,35,6

64. (COGNITIVE-RESTRUCTURING OR ASSERTIVENESS-TRAINING)/DE FROM 144,34,434,7,99,65,35,6

65. (RELAXATION-TRAINING OR RATIONAL-EMOTIVE OR FAMILY-RELATIONSHIP-THERAPY)/DE FROM 144,34, $434,7,99,65,35,6$

66. FAMILY-RELATIONS/DE

67. (COMMUNITY-REINFORCEMENT OR SELF-MONITORING OR SELF-CONTROL OR SELF-MANAGEMENT OR INTERPERSONAL-SKILLS)/DE FROM 44,34,434,7,99,65,35,6

68. (GOAL-SETTING)/DE FROM 144,34,434,7,99,65,35,6

69. (SOCIAL-SKILLS-TRAINING)/DE FROM 144,34,434,7,99,65,35,6

70. SOCIAL-RESPONSIBILITY/DE

71. (BASIC-SKILLS-TRAINING)/DE FROM 144,34,434,7,99,65,35,6

72. (RELAPSE-PREVENTION)/DE FROM 144,34,434,7,99,65,35,6

73. CRAVING/DE FROM 144,34,434,7,99,65,35,6

74. (TRIGGER OR COPING-SKILLS OR ANGER-MANAGEMENT OR GROUP-WORK)/DE FROM 144,34,434,7,99,65, 35,6

75. (LIFESTYLE-MODIFICATION)/DE FROM 144,34,434,7,99,65,35,6

76. (HIGH-INTENSITY-TRAINING OR RESETTLEMENT OR THROUGHCARE OR AFTERCARE OR AFTER-CARE)/ DE FROM 144,34,434,7,99,65,35,6

77. (BRIEF-SOLUTION OR BRIEF-INTERVENTIONS OR MINNESOTA-PROGRAM OR 12-STEP-PROGRAM OR TWELVE-STEP-PROGRAM)/DE FROM 144,34,434,7,99,65,35,6

77. (NEEDLE-EXCHANGE OR SYRINGE-EXCHANGE OR DUAL-DIAGNOSIS OR NARCOTICS-ANONYMOUS)/DE FROM 144,34,434,7,99,65,35,6

79. (SELF-HELP OR OUTREACH OR BAIL-SUPPORT OR ARREST-REFERRAL)/DE FROM 144,34,434,7,99,65,35,6 
(Continued)

80. (DRUG-TREATMENT OR TESTING-ORDERS OR CARAT)/DE FROM 144,34,434,7,99,65,35,6

81. (COMBINED-ORDERS OR DRUG-FREE)/DE FROM 144,34,434,7,99,65,35,6

82. (PEER-SUPPORT OR EVALUATION OR URINALYSIS OR DRUG-TESTING OR DRUG-TESTS)/DE FROM 144,34, $434,7,99,65,35,6$

83. (REHABILITATION OR RESIDENTIAL OR DISCRETE-SERVICES)/DE FROM 144,34,434,7,99,65,35,6

84. (ASRO OR PASRO ACUPUNCTURE OR BOOT-CAMP)/DE FROM 144,34,434,7,99,65,35,6

85. (WORK-ETHIC-CAMP OR DRUG-EDUCATION OR TASC OR TREATMENT-ACCOUNTABILITY)/DE FROM 144, $34,434,7,99,65,35,6$

86. (REMAND OR PRISON OR PRISONER OR PRISONERS OR OFFENDER OR OFFENDERS OR CRIMINAL OR CRIMINALS OR PROBATION OR COURT OR COURTS)/DE FROM 144,34,434,7,99,65,35,6

87. (SECURE-ESTABLISHMENTS OR SECURE-FACILITY)/DE FROM 144,34,434,7,99,65,35,6

88. (REOFFENDERS OR REINCARCERATION OR RECIDIVISM OR EX-OFFENDERS OR JAILS)/DE FROM 144,34, $434,7,99,65,35,6$

89. (INCARCERATION OR CONVICT OR CONVICTS OR FELON OR FELONS OR CONVICTIONS OR REVOCATION OR INMATE OR INMATES OR HIGH-SECURITY)/DE FROM 144,34,434,7,99,65,35,6

90. (SUBSTANCE-ABUSE OR SUBSTANCE-MISUSE OR SUBSTANCE-USE)/DE FROM 144,34,434,7,99,65,35,6

91. (DRUG-DEPENDANCE OR DRUG-DEPENDENCY OR DRUG-ABUSE OR DRUG-MISUSE OR DRUG-ADDICT OR DRUG-ADDICTION)/DE FROM 144,34,434,7,99,65,35,6

92. (CHEMICAL-DEPENDANCY OR OPIATE-DEPENDENCY OR HEROIN-DEPENDENCY OR CRACK-DEPENDENCY OR COCAINE-DEPENDENCY OR AMPHETAMINES OR ADDICTION OR DEPENDENCE-DISORDER OR DRUG-INVOLVED)/DE FROM 144,34,434,7,99,65,35,6

93. S40 OR S57:S85

94. S45 OR S86:S89

95. S55 OR S90:S92

96. S93 AND S94 AND S95 
Appendix 6. The CENTRAL Register of Controlled trials search strategy

\section{CENTRAL search}

1. prison*

2. offender*

3. (criminal* or probation or court ${ }^{*}$ )

4. (secure next establishment*)

5. reoffend*

6. reincarcerat*

7. recidiv*

8. exoffend*

9. (jail or jails or incarcerat*)

10. (secure next facilit*)

10(secure next facilit*)

11. (convict* or revocation or inmate* or (high next security))

\section{PRISONERS}

\section{LAW ENFORCEMENT}

14. JURISPRUDENCE

\section{CRIME}

16. \#1 or $\# 2$ or $\# 3$ or $\# 4$ or $\# 5$ or $\# 6$ or $\# 7$ or $\# 8$ or $\# 9$ or $\# 10$ or $\# 11$ or \#12 or \#13 or \#14 or \#15

\section{SUBSTANCE-RELATED DISORDERS}

18. ((substance or drug*) next (abuse* or misuse* or dependen* ${ }^{*}$ or use* or addict $\left.^{*}\right)$ )

19. (narcotics or chemical or opiate) next (dependen* or addict* or abuse* or misuse*))

20. ((heroin) next (addict* or dependen* or misuse* or abuse*))

21. ((crack) next (addict* or dependen* or misuse* or abuse* or use*))

22. ((cocaine next addict*) or (cocaine next dependenc $\left.{ }^{*}\right)$ or $\left(\right.$ cocaine next misuse $\left.^{*}\right)$ or $\left(\right.$ cocaine next abuse $\left.{ }^{*}\right)$ or $\left(\right.$ cocaine next use $\left.\left.^{*}\right)\right)$ 
(Continued)

23. ((amphetamine $\left.e^{*}\right)$ next (addict* or dependen* $^{*}$ or misuse* or abuse* or use $\left.\left.{ }^{*}\right)\right)$

24. (addicts or (dependence next disorder) or (drug next involved))

25. (street next drugs)

26. STREET DRUGS

27. DESIGNER DRUGS

28. NARCOTICS

29. COCAINE

30. AMPHETAMINES

31. ANALGESICS ADDICTIVE

32. ANALGESICS OPIOID

33. PSYCHOTROPIC DRUGS

34. opioid* or opiat*

$35 . \# 17$ or $\# 18$ or $\# 19$ or $\# 20$ or $\# 21$ or $\# 22$ or $\# 23$ or $\# 24$ or $\# 25$ or $\# 26$ or $\# 27$ or $\# 28$ or $\# 29$ or $\# 30$ or $\# 31$ or \#32 or \#33 or \#34

35. (\#16 and \#35)

\section{Appendix 7. SIGLE search strategy}

\section{SIGLE}

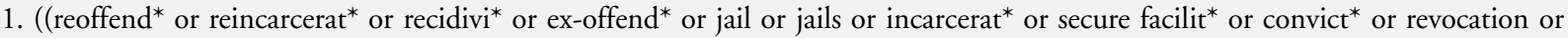
inmate*) in ti,ab)

2. ((remand or prison* or offender* or criminal* or probation or court or courts or secure establishment*) in ti,ab

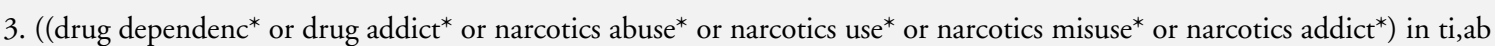

4. ((drug abuse* or drug misuse* or drug use* ${ }^{*}$ in ti,ab

5. ((substance abuse* or substance misuse* or substance use* ${ }^{*}$ in ti,ab

6. ((detox* or methadone maintenance or methadone prescri* ${ }^{*}$ or antagonist prescri* or dimorphine or naltrexone) in ti,ab 
(Continued)

7. ((dependence disorder or drug involved) in ti,ab

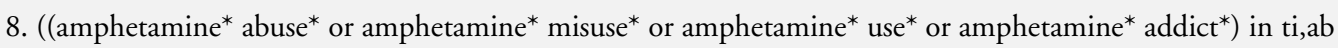

9. ((cocaine abuse* or cocaine misuse* or cocaine use* or cocaine addict* ${ }^{*}$ in ti,ab

10. ((crack abuse* or crack misuse* or crack use* or crack addict*) in ti,ab

11. ((heroin abuse* or heroin misuse* or heroin use* or heroin addict*) in ti,ab

12. ((chemical dependenc* or opiate abuse* or opiate misuse* or opiate use* or opiate addict*) in ti,ab

13. \#1 or \#2

14. $\# 3$ or $\# 4$ or $\# 5$ or $\# 6$ or $\# 7$ or $\# 8$ or $\# 9$ or $\# 10$ or $\# 11$ or $\# 12$

15. \#13 and \#14

Appendix 8. Sociological Abstracts search strategy

\section{Sociological Abstrac}

1. remand in de

2. detention in de

3. prisoners in de

4. prisons in de

5. offenders in de

6. parole in de

7. probation in de

8. correctional system in de

9. courts in de

10. imprisonment in de

11. criminal justice in de 


\section{(Continued)}

12. criminal proceedings in de

13. recidivism in de

14. jail in de

15. institutionalization (persons) in de

16. conviction/convictions in de

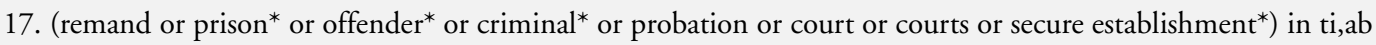

18. (reoffend* ${ }^{*}$ or reincarcerat* ${ }^{*}$ recidivi* or ex-offend* or jail or jails or incarcerat* ${ }^{*}$ or secure facilit* or convict* or revocation or inmate*) in ti,ab

19. $\# 1$ or $\# 2$ or $\# 3$ or $\# 4$ or $\# 5$ or $\# 6$ or $\# 7$ or $\# 8$ or $\# 9$ or $\# 10$ or $\# 11$ or $\# 12$ or $\# 13$ or $\# 14$ or $\# 15$ or $\# 16$ or $\# 17$ or $\# 18$ or $\# 19$

20. substance abuse in de

21. explode "Drug-Abuse" in DE

22. "Drug-Injection" in DE

23. explode "Narcotic-Drugs" in DE

24. "Cocaine-" in DE

25. "Addiction-" in DE

26. explode "Psychedelic-Drugs" in DE

27. (substance abuse* or substance misuse* or substance use*) in ti,ab

28. (drug abuse* or drug misuse* or drug use*) in ti,ab

29. (drug dependenc* or drug addict* or narcotics abuse* or narcotics use* or narcotics misuse* or narcotics addict*) in ti,ab

30. (chemical dependenc* or opiate abuse* or opiate misuse* or opiate use* or opiate addict*) in ti,ab

31. (heroin abuse* or heroin misuse* or heroin use* or heroin addict*) in ti,ab

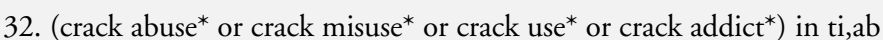

33. (cocaine abuse* or cocaine misuse* or cocaine use* or cocaine addict*) in ti,ab

34. (amphetamine* abuse* or amphetamine* misuse* or amphetamine* use* or amphetamine* addict*) in ti,ab

35. (dependence disorder or drug involved) in ti,ab 
(Continued)

36. \#22 or \#23 or \#24 or \#25 or \#26 or \#27 or \#28 or \#29 or \#30 or \#31 or \#32 or \#33 or \#34 or \#35

37. \#19 and \#36

38. "Detoxification-" in DE

39. "Methadone-Maintenance" in DE

40. "Counseling-" in DE

41. "Psychotherapy-" in DE

42. "Assertiveness-" in DE

43. (detoxification in de) or (methadone maintenance in de) or (treatment programs in de)

44. (counseling in de) or (psychotherapy in de) or (assertiveness in de) or (group therapy in de) or (goals in de) or (self control in de)

45. (interpersonal communication in de) or (social interaction in de) or (social competence in de) or (coping in de)

46. (social behavior in de) or (group work in de) or (lifestyle in de)

47. (after care in de) or (support networks in de) or (self help in de) or (self help groups in de) or (outreach programmes in de)

48. (outreach programs in de) or (referral in de) or (delinquency prevention in de) or (diversion/diversions in de)

49. (peer groups in de) or (peer influence in de) or (drug use screening in de) or (rehabilitation in de) or (work experience in de)

50. (detox* or methadone maintenance or methadone prescri* or antagonist prescri* or dimorphine or naltrexone) in ti,ab

51. (therapeutic communit* or motivational interview* or motivational enhance* or counseling or counselling or psychotherapy or cognitive behavi*) in ti,ab

52. (moral training or cognitive restructuring or assertiveness training or relaxation training) in ti,ab

53. (rational-emotive or rational emotive or family relationship therap* or community reinforcement or self monitoring or goal setting or self control training) in ti,ab

54. (self management or interpersonal skills or social skills or basic skills or relapse prevent* or prevent* relapse or craving reduc* or reduc* craving) in ti,ab

55. (trigger* or coping skills or anger management or group work or lifestyle modif* or high intensity training or resettlement or throughcare) in ti,ab

56. (aftercare or after care or brief solution or brief intervention* or 12 step* or twelve step* or minnesota program* or needle exchange or nes) in ti,ab

Pharmacological interventions for drug-using offenders (Review) 


\section{(Continued)}

57. (syringe exchange or dual diagnosis or narcotics anonymous or self help or selfhelp or outreach or bail support) in ti,ab

58. (arrest referral* ${ }^{*}$ or diversion or dtto or dttos or drug treatment or carat or carats or counseling assessment or combined orders) in ti, ab

59. (drug-free or drug free or peer support or evaluation* or urinalysis or drug testing or drug use screen* or rehabilitation or discrete service* or discrete program*) in ti,ab

60. (residential program* or residential scheme* or residential service*) in ti,ab

61. (asro or addressing substance or pasro or prisons addressing or acupuncture or shock or boot camp*) in ti,ab

62. (work ethic or drug education or tasc or treatment accountability) in ti,ab

63. \#38 or \#39 \#or \#40 or \#41 or \#42 or \#43 or \#44 or \#45 or \#46 or \#47 or \#48 or \#49 or \#50 or \#51 or \#52 or \#53 or \#54 or \# 55 or \#56 or \#57 or \#58 or \#59 or \#60 or \#61 or \#62

64. \#37 and \#63

\section{Appendix 9. ASSIA search strategy}

\section{ASSIA search}

1. remand

2. prison or prisoner or prisoners

3. offender*

4. criminal*

5. probation

6. court or courts

7. tribunal or tribunals

8. secure establishment*

9. secure facilit*

10. reoffend*

11. reincarcerat*

12. recidivi*

Pharmacological interventions for drug-using offenders (Review)

Copyright $\odot 2015$ The Cochrane Collaboration. Published by John Wiley \& Sons, Ltd. 


\section{(Continued)}

13. ex-offender*

14. jail or jails

15. incarcerat*

16. convict or convicts

17. convicted

18. felon or felons

19. conviction*

20. reconviction*

21. high security

22. law enforcement

23. Substance abuse* or substance misuse* or substance use*

24. drug dependanc* or drug abuse* or drug use*

25. drug misuse* or drug addict*

26. narcotics addict* narcotics use* narcotics misuse* narcotics abuse*

27. chemical dependanc*

28. opiates

29. heroin

30. crack

31. cocaine

32. amphetamines

33. cocaine

34. addiction

35. dependence disorder*

36. drug involved

37. Substance-related disorders

Pharmacological interventions for drug-using offenders (Review)

Copyright @ 2015 The Cochrane Collaboration. Published by John Wiley \& Sons, Ltd. 
(Continued)

38. amphetamine-related disorders

39. cocaine-related disorders

40. marijuana abuse

41. opioid-related disorders

42. street drugs

43. designer drugs

44.1 or 2 or 3 or 4 or 5 or 6 or 7 or 8 or 9 or 10 or 11 or 12 or 13 or 14 or 15 or 16 or 17 or 18 or 19 or 20 or 21 or 22

45.23 or 24 or 25 or 26 or 27 or 28 or 29 or 30 or 31 or 32 or 33 or 34 or 35 or 36 or 37 or 38 or 39 or 40 or 41 or 42 or 43

46. 44 and 45

\section{Appendix I0. HMIC search strategy}

\section{HMIC}

1. remand in de

2. detention in de

3. prisoners in de

4. prisons in de

5. offenders in de

6. parole in de

7. probation in de

8. correctional system in de

9. courts in de

10. imprisonment in de

11. criminal justice in de

12. criminal proceedings in de

Copyright $\odot 2015$ The Cochrane Collaboration. Published by John Wiley \& Sons, Ltd. 


\section{(Continued)}

13. recidivism in de

\section{4. jail in de}

15. institutionalization (persons) in de

16. conviction/convictions in de

17. (remand or prison* or offender* or criminal* or probation or court or courts or secure establishment*) in ti,ab

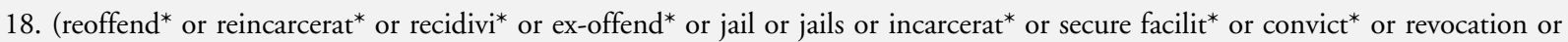
inmate* ${ }^{*}$ in ti,ab

$19 . \# 1$ or $\# 2$ or $\# 3$ or $\# 4$ or $\# 5$ or $\# 6$ or $\# 7$ or $\# 8$ or $\# 9$ or $\# 10$ or $\# 11$ or $\# 12$ or $\# 13$ or $\# 14$ or $\# 15$ or $\# 16$ or \#17 or \#18

20. substance abuse in de

21. explode "Drug-Abuse" in DE

22. "Drug-Injection” in DE

23. explode "Narcotic-Drugs" in DE

24. "Cocaine-" in DE

25. "Addiction-" in DE

26. explode "Psychedelic-Drugs" in DE

27. (substance abuse* or substance misuse* or substance use*) in ti,ab

28. (drug abuse* or drug misuse* or drug use*) in ti,ab

29. (drug dependenc* or drug addict* or narcotics abuse* or narcotics use* or narcotics misuse* or narcotics addict*) in ti,ab

30. (chemical dependenc* or opiate abuse* or opiate misuse* or opiate use* or opiate addict*) in ti,ab

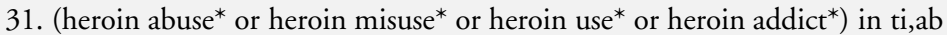

32. (crack abuse* or crack misuse* or crack use* or crack addict*) in ti,ab

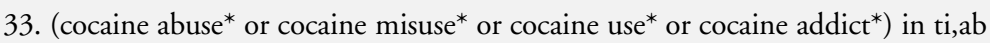

34. (amphetamine* abuse* or amphetamine* misuse* or amphetamine* use* or amphetamine* addict*) in ti,ab

35. (dependence disorder or drug involved) in ti,ab

$36 . \# 20$ or \#21 or \#22 or \#23 or \#24 or \#25 or \#26 or \#27 or \#28 or \#29 or \#30 or \#31 or \#32 or \#33 or \#34 or \#35 


\section{Appendix I I. National Research Register search strategy}

\section{NRR search}

1. REMAND

2. PRISON*

3. OFFENDER*

4. ((CRIMINAL* or PROBATION) or COURT) or COURTS)

5. (SECURE next ESTABLISHMENT*)

6. REOFFEND*

7. REINCARCERAT*

8. RECIDIV*

9. EXOFFEND*

10. ((JAIL or JAILS) or INCARCERAT*)

11. (SECURE next FACILIT*)

12. ((CONVICT* or REVOCATION) or INMATE*) OR (HIGH next SECURITY))

13. PRISONERS:ME

14. LAW-ENFORCEMENT:ME

15. JURISPRUDENCE:ME

16. CRIME:ME

17. $\# 1$ or $\# 2$ or $\# 3$ or $\# 4$ or $\# 5$ or $\# 6$ or $\# 7$ or $\# 8$ or $\# 9$ or $\# 10$

18. $\# 11$ or $\# 12$ or $\# 13$ or $\# 14$ or $\# 15$ or $\# 16$

19. \#17 or \#18

20. ((SUBSTANCE next ABUSE*) or (SUBSTANCE next MISUSE*)) OR (DRUG NEXT DEPENDENC*)) OR (DRUG NEXT ABUSE*)) OR (DRUG NEXT MISUSE*)) OR (DRUG NEXT USE*)) OR (DRUG NEXT ADDICTION)) 
21. ((NARCOTICS or (CHEMICAL next DEPENDENC*)) OR (OPIATE NEXT ADDICT*)) OR (OPIATE NEXT DEPENDENC*)) OR (OPIATE NEXT ABUSE*)) OR (OPIATE NEXT MISUSE*))

22. ((HEROIN next ADDICT*) or (HEROIN next DEPENDENC*)) OR (HEROIN NEXT MISUSE*)) OR (HEROIN NEXT $\left.\left.\mathrm{ABUSE}^{*}\right)\right)$

23. ((CRACK next ADDICT*) or (CRACK next DEPENDENC*)) OR (CRACK NEXT MISUSE*)) OR (CRACK NEXT ABUSE*)) OR (CRACK NEXT USE*))

24. ((COCAINE next ADDICT*) or (COCAINE next DEPENDENC*)) OR (COCAINE NEXT MISUSE*)) OR (COCAINE NEXT ABUSE*)) OR (COCAINE NEXT USE*))

25. ((AMPHETAMINE* next ADDICT*) or (AMPHETAMINE* next DEPENDENC*)) OR (AMPHETAMINE* NEXT MISUSE*)) OR (AMPHETAMINE* NEXT ABUSE*)) OR (AMPHETAMINE* NEXT USE*))

26. ((ADDICTS or (DEPENDENCE next DISORDER)) OR (DRUG NEXT INVOLVED))

27. (SUBSTANCE-RELATED and DISORDERS:ME)

28. SUBSTANCE-RELATED-DISORDERS:ME

29. AMPHETAMINE-ABUSE:ME

30. COCAINE-ABUSE:ME

31. MARIJUANA-ABUSE:ME

32. OPIOID-RELATED-DISORDERS:ME

33. PHENCYCLIDINE-ABUSE:ME

34. SUBSTANCE-ABUSE-INTRAVENOUS:ME

35. SUBSTANCE-WITHDRAWAL-SYNDROME:ME

36. (STREET next DRUGS)

38. STREET-DRUGS:ME

39. DESIGNER-DRUGS:ME

40. NARCOTICS:ME

41. (COCAINE:ME or AMPHETAMINES:ME)

42. ANALGESICS-ADDICTIVE:ME

43. ANALGESICS-OPIOID:ME 
(Continued)

\section{PSYCHOTROPIC-DRUGS:ME}

$45 . \# 20$ or \#21 or \#22 or \#23 or \#24 or \#25 or \#26 or \#27 or \#28 or \#29 or \#30 or \#31 or \#32 or \#33 or \#34 or \#35 or \#36 or \#37 or \#38 or \#39 or \#40 or \#41 or \#42 or \#43 or \#44

46. 19 and 45

\section{Appendix I2. PAIS search strategy}

\section{PAIS}

1. ((reoffend* or reincarcerat $^{*}$ or recidivi* or ex-offend* ${ }^{*}$ or jail or jails or incarcerat* ${ }^{*}$ or secure facilit* or convict* or revocation or inmate $\left.{ }^{*}\right)$ in ti,ab)

2. ((remand or prison* or offender* or criminal* or probation or court or courts or secure establishment*) in ti,ab)

3. ((drug dependenc* or drug addict* or narcotics abuse* or narcotics use* or narcotics misuse* or narcotics addict*) in ti,ab)

4. ((drug abuse* or drug misuse* or drug use* in ti,ab) or ((substance abuse* or substance misuse* or substance use*) in ti,ab)

5. ((detox* or methadone maintenance or methadone prescri* or antagonist prescri* or dimorphine or naltrexone) in ti,ab)

6. ((dependence disorder or drug involved) in ti,ab)

7. ((amphetamine* abuse* or amphetamine* misuse* or amphetamine* use $^{*}$ or amphetamine* addict $\left.{ }^{*}\right)$ in ti,ab)

8. ((cocaine abuse* or cocaine misuse* or cocaine use* or cocaine addict*) in ti,ab)

9. ((crack abuse* or crack misuse* or crack use* or crack addict* ${ }^{*}$ in ti,ab)

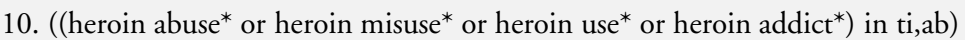

11. ((chemical dependenc* or opiate abuse* or opiate misuse* or opiate use* or opiate addict*) in ti,ab)

12. ((moral training or cognitive restructuring or assertiveness training or relaxation training) in ti,ab)

13. ((therapeutic communit* or motivational interview* or motivational enhance* or counseling or counselling or psychotherapy or cognitive behavi*) in ti,ab)

14. ((work ethic or drug education or tasc or treatment accountability) in ti,ab)

15. ((asro or addressing substance or pasro or prisons addressing or acupuncture or shock or boot camp*) in ti,ab) 


\section{(Continued)}

16. ((arrest referral* or diversion or dtto or dttos or drug treatment or carat or carats or counseling assessment or combined orders) in ti,ab)

17. ((residential program* or residential scheme* or residential service*) in ti,ab)

18. ((syringe exchange or dual diagnosis or narcotics anonymous or self help or selfhelp or outreach or bail support) in ti,ab)

19. ((drug-free or drug free or peer support or evaluation* or urinalysis or drug testing or drug use screen* or rehabilitation or discrete service* or discrete program*) in ti,ab)

20. ((aftercare or after care or brief solution or brief intervention* or 12 step* $^{*}$ or twelve step* or minnesota program* or needle exchange or nes) in ti,ab)

21. ((trigger* or coping skills or anger management or group work or lifestyle modif* or high intensity training or resettlement or throughcare) in ti,ab)

22. ((self management or interpersonal skills or social skills or basic skills or relapse prevent* or prevent* ${ }^{*}$ relapse or craving reduc* ${ }^{*}$ reduc* craving) in ti,ab)

24. ((rational-emotive or rational emotive or family relationship therap* or community reinforcement or self monitoring or goal setting or self control training) in ti,ab)

25. $\# 1$ or \#2

26. \#3 or \#4 or \#5 or \#6 or \#7 or \#8 or 9 or \#10 or \#11

$27 . \# 12$ or $\# 13$ or $\# 14$ or $\# 15$ or $\# 16$ or $\# 17$ or $\# 18$ or \#19 or \#20 or \#21 or \#22 or \#23 or \#24

28. 25 and $\# 26$ and $\# 27$

\section{Appendix 13. Criminal Justice Abstracts search strategy}

\section{CJA search}

1. (substance abuse* or substance misuse* or substance use or substance users) in ti,ab,de

2. substance related in ti,ab,de

3. drug related in ti,ab,de

4. (drug dependenc* or drug abuse* or drug misuse* or drug use or drug users or drug addiction) in ti,ab,de

5. (narcotics use or narcotics users or narcotics abuse* or narcotics misuse* or chemical dependenc*) in ti,ab,de 


\section{(Continued)}

6. (opiates or heroin or crack or cocaine or amphetamines or addict or addicts or addicted or dependence disorder* or drug involved) in ti,ab,de

7. (designer drugs or street drugs or polydrug misuse* or polydrug abuse*) in ti,ab,de

\section{8. \#1 or \#2 or \#3 or \#4 or \#5 or \#6 or \#7}

9. ((antagonist near prescri*) or diamorphine or naltrexone) in ti,ab,de

10 (therapeutic communit* or (motivational near interview*)) in ti,ab,de

11. (motivational near enhancement) in ti,ab,de

12. (counselling or counseling) in ti,ab,de

13. (psychotherap* or cognitive behav* or behav* therap* or (moral near training)) in ti,ab,de

14. (cognitive restructuring or (assertiveness near train*) or relaxation training) in ti,ab,de

15. (rational emotive or family relationship therap*) in ti,ab,de

16. (community reinforcement or self monitoring or goal setting or goalsetting) in ti,ab,de

17. (self control near training) in ti,ab, de

18. (self management) in ti,ab,de

19. (interpersonal skills near training) in ti,ab,de

20. ((social skills or basic skills) near training) in ti,ab,de

21. ((relapse near prevent $\left.{ }^{*}\right)$ or $\left(\right.$ craving near reduc $\left.\left.{ }^{*}\right)\right)$ in ti,ab,de

22. (trigger* or coping skills or anger management or group work or (lifestyle near modif*)) in ti,ab,de

23. (high intensity training or resettlement or throughcare or aftercare or after care) in ti,ab,de

24. (brief solution* or brief intervention*) in ti,ab,de

25. (minnesota in ti,ab) in ti,ab,de

26. (12 step* or twelve step*) in ti,ab,de

27. (needle exchange or nes or syringe exchange) in ti,ab,de

28. (dual diagnosis or narcotics anonymous or self help or selfhelp or outreach) in ti,ab,de 
(Continued)

29. (bail support or bail program* or arrest referral* or diversion or dtto* or drug treatment) in ti,ab,de

30. (carat or counselling assessment or counseling assessment) in ti,ab,de

31. (combined order* or drug free wing* or drug free environment* or peer support) in ti,ab,de

32. (user evaluations or urinalys* or urinanalys* or drug test* or rehab* or discrete service*) in ti,ab,de

33. (discrete program* or residential program* or residential scheme*) in ti,ab,de

34. (asro or addressing substance*) in ti,ab,de

35. (pasro or prisons addressing) in ti,ab,de

36. (acupuncture or shock or boot camp or boot camps or work ethic camp*) in ti,ab,de

37. (drug education or tasc or treatment accountability) in ti,ab,de

38. (detoxification or detox or methadone maintenance or (methadone near prescri*)) in ti,ab,de

$39 . \# 9$ or \#10 or \#11 or \#12 or \#13 or \#14 or \#15 or \#16 or \#17 or \#18 or \#19 or \#20 or \#21 or \#22 or \#23 or \#24 or \#25 or \#26 or \#27 or \#28 or \#29

40. \#30 or \#31 or \#32 or \#33 or \#34 or \#35 or \#36 or \#37 or \#38 or \#39

41. \#39 or \#40

42. \#8 and \#41

9. \#42 and (PY > “1979")

\section{Appendix 14. Criteria for assessing risk of bias}

\begin{tabular}{lll}
\hline Item & Judgment & Description \\
\hline $\begin{array}{l}\text { 1. Random sequence generation (selection } \\
\text { bias) }\end{array}$ & Low risk & $\begin{array}{l}\text { The investigators describe a random component in the sequence gener- } \\
\text { ation process such as: random number table; computer random num- } \\
\text { ber generator; coin tossing; shuffling cards or envelopes; throwing dice; } \\
\text { drawing of lots; minimization }\end{array}$ \\
\hline
\end{tabular}

High risk

The investigators describe a non-random component in the sequence generation process such as: odd or even date of birth; date (or day) of admission; hospital or clinic record number; alternation; judgement of the clinician; results of a laboratory test or a series of tests; availability of 
the intervention

Unclear risk Insufficient information about the sequence generation process to permit judgement of low or high risk

2. Allocation concealment (selection bias) Low risk

Investigators enrolling participants could not foresee assignment because one of the following, or an equivalent method, was used to conceal allocation: central allocation (including telephone, web-based, and pharmacycontrolled, randomisation); sequentially numbered drug containers of identical appearance; sequentially numbered, opaque, sealed envelopes

High risk Investigators enrolling participants could possibly foresee assignments because one of the following method was used: open random allocation schedule (e.g. a list of random numbers); assignment envelopes without appropriate safeguards (e.g. if envelopes were unsealed or nonopaque or not sequentially numbered); alternation or rotation; date of birth; case record number; any other explicitly unconcealed procedure

Unclear risk Insufficient information to permit judgement of low or high risk This is usually the case if the method of concealment is not described or not described in sufficient detail to allow a definite judgement

3. Blinding of participants and providers Low risk (performance bias)

Objective outcomes
No blinding or incomplete blinding, but the review authors judge that the outcome is not likely to be influenced by lack of blinding; Blinding of participants and key study personnel ensured, and unlikely that the blinding could have been broken
4. Blinding of participants and providers Low risk (performance bias)

Subjective outcomes
Blinding of participants and providers and unlikely that the blinding could have been broken;

High risk

No blinding or incomplete blinding, and the outcome is likely to be influenced by lack of blinding;

Blinding of key study participants and personnel attempted, but likely that the blinding could have been broken, and the outcome is likely to be influenced by lack of blinding

Unclear risk Insufficient information to permit judgement of low or high risk;

5. Blinding of outcome assessor (detection Low risk bias)

Objective outcomes

6.Blinding of outcome assessor (detection Low risk bias)

Subjective outcomes
No blinding of outcome assessment, but the review authors judge that the outcome measurement is not likely to be influenced by lack of blinding; Blinding of outcome assessment ensured, and unlikely that the blinding could have been broken

No blinding of outcome assessment, but the review authors judge that the outcome measurement is not likely to be influenced by lack of blinding; Blinding of outcome assessment ensured, and unlikely that the blinding could have been broken 
High risk No blinding of outcome assessment, and the outcome measurement is likely to be influenced by lack of blinding;

Blinding of outcome assessment, but likely that the blinding could have been broken, and the outcome measurement is likely to be influenced by lack of blinding

Unclear risk Insufficient information to permit judgement of low or high risk;

7. Incomplete outcome data (attrition bias) Low risk For all outcomes except retention in treatment or drop out
No missing outcome data;

Reasons for missing outcome data unlikely to be related to true outcome (for survival data, censoring unlikely to be introducing bias);

Missing outcome data balanced in numbers across intervention groups, with similar reasons for missing data across groups;

For dichotomous outcome data, the proportion of missing outcomes compared with observed event risk not enough to have a clinically relevant impact on the intervention effect estimate;

For continuous outcome data, plausible effect size (difference in means or standardized difference in means) among missing outcomes not enough to have a clinically relevant impact on observed effect size;

Missing data have been imputed using appropriate methods

All randomised patients are reported/analysed in the group they were allocated to by randomisation irrespective of non-compliance and cointerventions (intention to treat)

High risk Reason for missing outcome data likely to be related to true outcome, with either imbalance in numbers or reasons for missing data across intervention groups;

For dichotomous outcome data, the proportion of missing outcomes compared with observed event risk enough to induce clinically relevant bias in intervention effect estimate;

For continuous outcome data, plausible effect size (difference in means or standardized difference in means) among missing outcomes enough to induce clinically relevant bias in observed effect size;

'As-treated' analysis done with substantial departure of the intervention received from that assigned at randomisation;

Unclear risk Insufficient information to permit judgement of low or high risk (e.g. number randomised not stated, no reasons for missing data provided; number of drop out not reported for each group);

8 Selective reporting (reporting bias) Low risk
The study protocol is available and all of the study's pre-specified (primary and secondary) outcomes that are of interest in the review have been reported in the pre-specified way;

The study protocol is not available but it is clear that the published reports include all expected outcomes, including those that were pre-specified (convincing text of this nature may be uncommon) 


\begin{tabular}{|c|c|c|}
\hline & High risk & $\begin{array}{l}\text { Not all of the study's pre-specified primary outcomes have been reported; } \\
\text { One or more primary outcomes is reported using measurements, analysis } \\
\text { methods or subsets of the data (e.g. sub scales) that were not pre-specified; } \\
\text { One or more reported primary outcomes were not pre-specified (unless } \\
\text { clear justification for their reporting is provided, such as an unexpected } \\
\text { adverse effect); } \\
\text { One or more outcomes of interest in the review are reported incompletely } \\
\text { so that they cannot be entered in a meta-analysis; } \\
\text { The study report fails to include results for a key outcome that would be } \\
\text { expected to have been reported for such a study }\end{array}$ \\
\hline & Unclear risk & Insufficient information to permit judgement of low or high risk \\
\hline \multirow[t]{3}{*}{ 9. Other bias* } & Low risk & $\begin{array}{l}\text { Evidence to suggest other problems identified with the study which } \\
\text { might threaten the validity of the random allocation, attrition or data } \\
\text { integrity and results of the trial }\end{array}$ \\
\hline & High risk & $\begin{array}{l}\text { Evidence to suggest that the trial might be underpowered/problems with } \\
\text { the random allocation process leading to potential self selection bias/ } \\
\text { issues of analysis not conducted using intent to treat analysis or evidence } \\
\text { of missing data. Concerns of attrition and measurement error including } \\
\text { reliance on self report measures }\end{array}$ \\
\hline & Unclear risk & insufficient information to permit judgement of low or high risk \\
\hline
\end{tabular}

\section{WHAT'S NEW}

Last assessed as up-to-date: 31 May 2014.

\begin{tabular}{l|l|l}
\hline Date & Event & Description \\
\hline 2 March 2015 & New citation required and conclusions have changed & $\begin{array}{l}\text { In the previous version pharmacological interventions for } \\
\text { drug-using offenders appeared to reduce overall subsequent } \\
\text { drug use and criminal activity (but to a lesser extent), while } \\
\text { with the introduction of new studies agonist treatments did } \\
\text { not seem effective in reducing drug use or criminal activity }\end{array}$ \\
\hline 29 July 2014 & New search has been performed & $\begin{array}{l}\text { This latest update reflects an additional four new trials (and } \\
\text { one ongoing trial) with new follow-up data on two existing } \\
\text { trials with searches conducted up until May 2014 }\end{array}$ \\
\hline
\end{tabular}

Pharmacological interventions for drug-using offenders (Review) 


\section{H I S T O R Y}

Review first published: Issue 12, 2013

\begin{tabular}{|c|c|c|}
\hline Date & Event & Description \\
\hline 27 January 2014 & Amended & Plain language summary title correction \\
\hline 16 July 2012 & New search has been performed & $\begin{array}{l}\text { This review has been updated using searches to } 21 \text { March } \\
2013 \text {. The review represents one in a family of four re- } \\
\text { views. The other reviews cover non- pharmacological in- } \\
\text { terventions for drug-using offenders and interventions } \\
\text { for drug-using female offenders and offenders with co- } \\
\text { occurring mental illness. This new review of pharmaco- } \\
\text { logical interventions with drug-using offenders contains } \\
17 \text { randomised controlled trials. Six of the } 17 \text { trials are } \\
\text { awaiting classification for the review; the remaining } 11 \\
\text { trials represent a total of } 2,678 \text { participants }\end{array}$ \\
\hline 2 March 2012 & New search has been performed & $\begin{array}{l}\text { The updated edit of this review produced a new docu- } \\
\text { ment with additional findings reflecting searches up to } \\
11 \text { November } 2011 \text {. Five new review authors have been } \\
\text { added to this version of the review, including Steven } \\
\text { Duffy, Rachael McCool, Matthew Neilson, Catherine } \\
\text { Hewitt and Marrissa Martyn-St James }\end{array}$ \\
\hline 19 May 2006 & New citation required and conclusions have changed & Substantive amendment \\
\hline
\end{tabular}

\section{CONTRIBUTIONS OFAUTHORS}

Searches were constructed and conducted by DF. Three independent review authors inspected the search hits by reading the titles and abstracts (AEP, MN, RW). Each potentially relevant study located in the search was obtained as a full article and was independently assessed for inclusion by two review authors. In the case of discordance, a third independent review author arbitrated. Where it was not possible to evaluate the study because of language problems or missing information, the studies were classified as 'translation/ information required to determine decision' until a translation or further details were provided. Four review authors conducted data extraction for the papers (MM-SJ, JMG, RW, and MN), and review author CG conducted data extraction and a narrative summary of the cost-effectiveness studies. The results were compiled and organised by MM-ST, MN, CH, RW and AEP, and all eight authors contributed towards the final draft text. 


\section{DECLARATIONSOF INTEREST}

Amanda E Perry have no interests to declare relating to this work Matthew Neilson have no interests to declare relating to this work

Marrissa Martyn-St James have no interests to declare relating to this work

Julie M Glanville have no interests to declare relating to this work

Dave Fox have no interests to declare relating to this work

Rebecca Woodhouse have no interests to declare relating to this work

Catherine Hewitt have no interests to declare relating to this work

\section{SOURCES OF SUPPORT}

\section{Internal sources}

- Reviewer from Cochrane Drugs and Alcohol Group, Other.

A reviewer from the Drugs and Alcohol Group provided the researchers with the results of a search strategy for three databases

\section{External sources}

- The Department of Health funded the original review, UK.

\section{DIFFERENCES BETWEEN PROTOCOLANDREVIEW}

The original review Perry 2006 has been split up into different reviews and so there is no dedicated protocol for this particular review

\section{INDEX TERMS}

\section{Medical Subject Headings (MeSH)}

*Criminals; Buprenorphine [therapeutic use]; Heroin [therapeutic use]; Methadone [therapeutic use]; Naltrexone [analogs \& derivatives; therapeutic use]; Narcotics [therapeutic use]; Randomized Controlled Trials as Topic; Substance-Related Disorders [*drug therapy]

\section{MeSH check words}

Adult; Female; Humans; Male 